\title{
Synthesis of Quinolines via the Metal-Free Visible-Light-Mediated Radical Azidation of Cyclopropenes
}

\author{
Vladyslav Smyrnov, Bastian Muriel, Jerome Waser \\ Laboratory of Catalysis and Organic Synthesis, Institut des Sciences et Ingénierie Chimique, Ecole Polytechnique Fédérale \\ de Lausanne, Lausanne, Switzerland
}

Supporting Information Placeholder

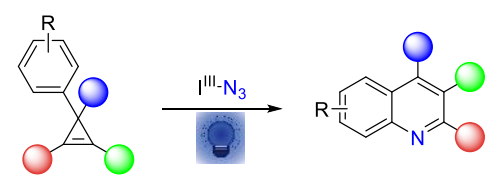

\begin{abstract}
We report the synthesis of quinolines using cyclopropenes and an azidobenziodazolone (ABZ) hypervalent-iodine reagent as azide radical source under visible light irradiation. Multi-substituted quinoline products were obtained in $34-81 \%$ yield. The reaction was most efficient for 3-trifluoromethylcyclopropenes, affording valuable 4-trifluoromethylquinolines. The transformation probably proceeds through cyclization of an iminyl radical formed by addition of the azide radical on the cyclopropene double bond, followed by ring-opening and fragmentation.
\end{abstract}

As the smallest cyclic alkenes, cyclopropenes contain a substantial ring strain (ca $228 \mathrm{~kJ}$. Mol-1). ${ }^{1}$ Nevertheless, cyclopropenes bearing one or two substituents on the third position are generally stable. Due to the presence of the ring strain, cyclopropenes are useful intermediates in organic synthesis. ${ }^{2}$ However, reports of reactions relying on the addition of radicals to cyclopropenes remain scarce, despite the fast growing use of radicals for alkene functionalization (Scheme 1a). The first example of such a reaction was a radical hydrostannylation reported by Nakamura in $1994 .^{3}$ Different research groups then reported the addition of carbon-centered radicals to the strained double bond, ${ }^{4}$ resulting in hydrotrichloromethylation (eq. 1), carbocyanation (eq. 2), and 3+2 annulation of cyclopropenes (eq. 3) among other transformations (Scheme 1a).

In particular, the addition of heteroatom-centered radicals has been mostly neglected. Recently, our group reported the radical azidation of cyclopropenes to give alkenylnitriles (Scheme 1b). ${ }^{5}$ During optimization of this work, small amounts of quinolines were observed as side products for aryl-substituted cyclopropenes, in the absence of $\mathrm{CuCl}_{2}$. Quinolines have found numerous applications in medicine, industry, ${ }^{6}$ and material sciences. ${ }^{7}$ This heterocycle is present in the structure of many natural products $^{8}$ and synthetic bioactive compounds, including examples of approved drugs. ${ }^{9}$ For instance, the structures of the antimalarial drugs quinine (1), chloroquine (2), and the acetylcholinesterase inhibitor tacrine (3) are based on the quinoline core (Scheme 2a). Many classical synthetic methods exist for the synthesis of quinolines, such as the Skraup, Friedlander, Doebner-von-Miller, Conrad-Limpach and Pfitzinger reactions. ${ }^{10}$ Most of these methods require strongly acidic or basic conditions, not compatible with sensitive functionalities. Therefore, the use of radical-based methods for quinoline synthesis is particularly attractive. ${ }^{11}$ A special subclass of such methods are transformations based on cyclizations of iminyl radicals onto the aryl ring.

Scheme 1. Radical-mediated transformations of cyclopropenes

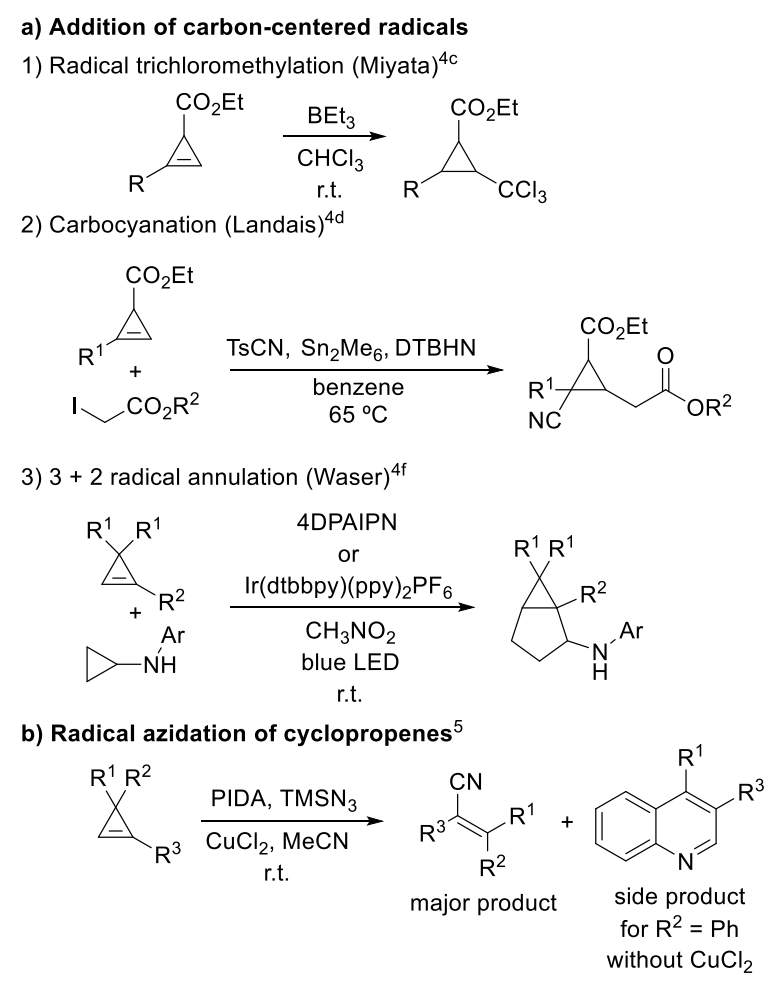

These radicals can be accessed via the homolysis of the N-O bond in oxime derivatives, ${ }^{12}$ or by fragmentation of $\alpha$-azidorad- 
ical species (Scheme 2b). ${ }^{13}$ Methods to generate the desired iminyl radical remain limited and new approaches are highly desirable to give access to different substitution patterns. Therefore, we decided to optimize the formation of the quinoline product resulting from the radical azidation of cyclopropenes (Scheme 1b), and report herein a new synthesis of quinolines from cyclopropenes, which is particularly efficient for the synthesis of trifluoromethylated derivatives (Scheme 2c).

Scheme 2. Quinolines: bioactive compounds and radicalbased synthetic strategies

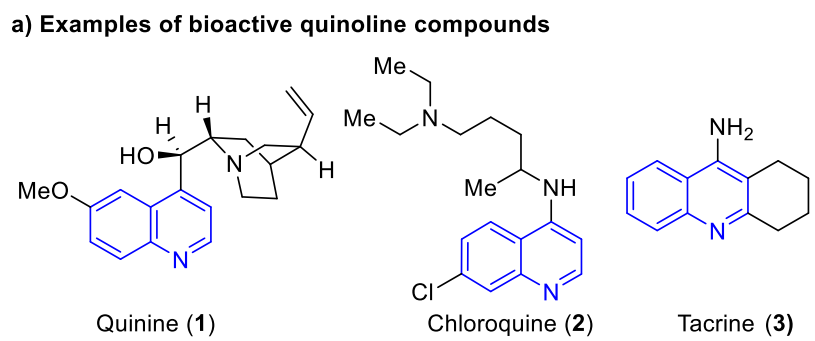

b) Quinoline synthesis via cyclisation of iminyl radicals

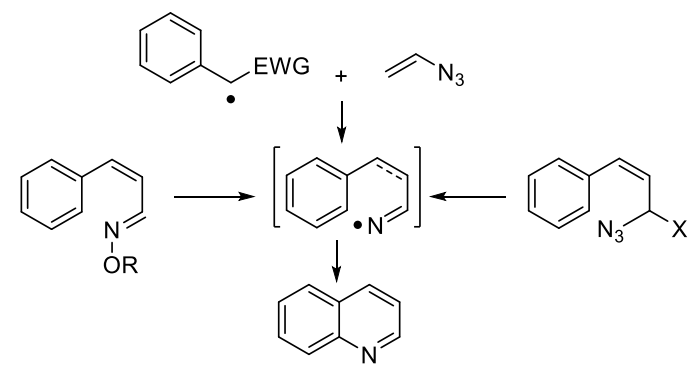

c) This work: quinoline synthesis from cyclopropenes

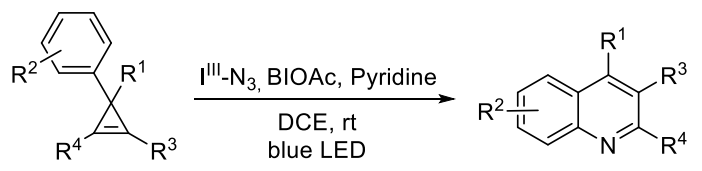

Using cyclopropene (4a) as the model substrate, we were pleased to find that the use of the safe hypervalent iodine reagent azidobenziodazolone $(\mathrm{ABZ}, \mathbf{6}),{ }^{14}$ in the presence of the organic dyes 1,2,3,5-tetrakis(carbazol-9-yl)-4,6-dicyanobenzene $(4 \mathrm{CzIPN})^{15}$ and 1,3-dicyano-2,4,5,6-tetrakis(diphenylamino)benzene (4DPAIPN) ${ }^{16}$ in DCE gave the desired quinoline (5a) as the single product albeit in low yield (Table 1, entries 1,2). A control experiment revealed that in the absence of a photocatalyst the reaction proceeded even slightly better (entry 3 ). However, we found that the reaction outcome was strongly dependent on the batch of $\mathrm{ABZ}$ we used, resulting in no product formation in the worst case. We thought that traces of iodine(III) impurities could act as initiator for the reaction. Indeed, the use of $20 \mathrm{~mol} \%$ of acetoxybenziodoxolone (BIOAc, 7) ${ }^{17}$ as an additive made the reaction reproducible, giving the product in $34 \%$ yield (entry 4 ). No improvement was seen when using one equivalent of BIOAc (entry 5). The addition of bases to the reaction mixture was examined (entries 6-8), resulting in improved yield, with pyridine performing the best (entry 8). Despite numerous attempts to increase the reaction yield by finetuning the reaction conditions, no improvement could be achieved. As quinoline 5a was the only product isolable in a substantial amount, we speculate that polymerization of cyclopropene 1a was occurring as the main side reaction.
Table 1. Optimization of the reaction conditions with cyclopropene $4 \mathbf{a}^{\mathrm{a}}$

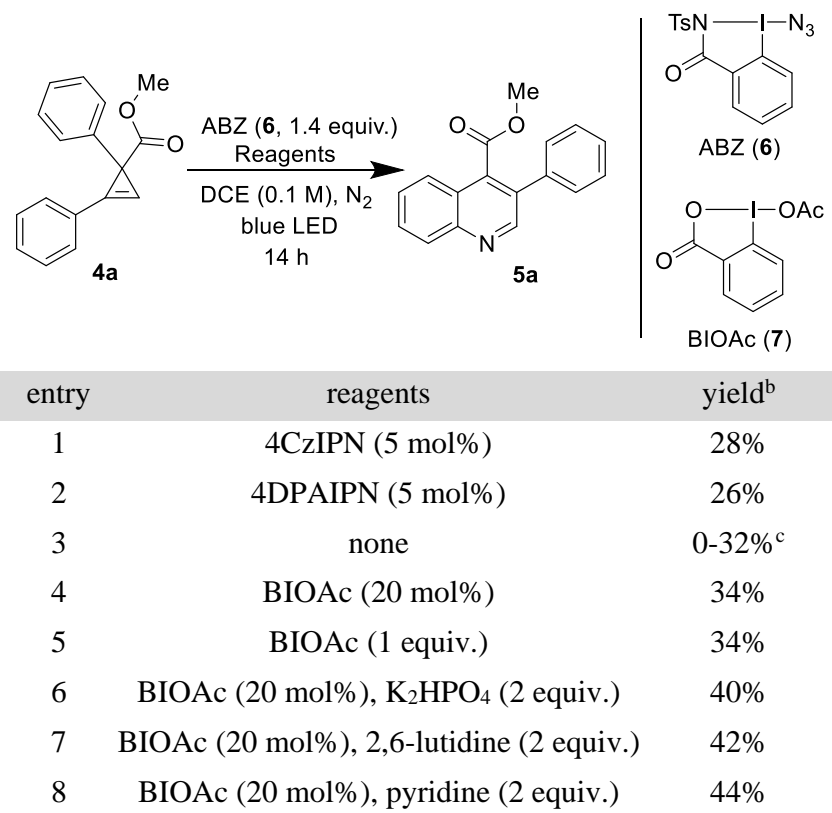

${ }^{a}$ The reactions were performed on $0.1 \mathrm{mmol}$ scale. ${ }^{\mathrm{b}}$ The yield was determined by ${ }^{1} \mathrm{H}$ NMR of the concentrated reaction mixture using $\mathrm{CH}_{2} \mathrm{Br}_{2}$ as an internal standard. ${ }^{\mathrm{C}}$ The reaction outcome was dependent on the batch of ABZ.

Despite the moderate yield obtained for the synthesis of $\mathbf{5 a}$, we turned to explore the scope of the reaction, as we expected that the reaction efficiency would be highly dependent on the structure of the cyclopropene. Starting materials were prepared by metal-catalyzed cyclopropenation of alkynes with diazo compounds, using $\mathrm{Rh}$ catalyst for terminal alkynes ${ }^{18}$ and $\mathrm{Ag}$ catalyst for internal ones. ${ }^{19}$ Cyclopropenes $\mathbf{4 e - g}$ were prepared by 1,2-elimination of the corresponding cyclopropylbromides. ${ }^{20}$ We started by evaluating the influence of the substituent at position 3 of the cyclopropene ring. Different ester substituted cyclopropenes 4a-d were converted to the corresponding quinoline products 5a-d in 38-43\% yield. For mono-substituted cyclopropene 4d, an increased amount of ABZ (6) and prolonged reaction time were required for full conversion. 3-Aryl $(\mathbf{4 e}, \mathbf{4 f})$ and 3-alkyl (4g) substituted cyclopropenes were also found to be suitable substrates for the transformation. Aryl substituted quinolines $\mathbf{5 e}$ and $\mathbf{5 f}$ could be obtained in higher yields $(68 \%$ and $81 \%$ respectively). To our delight, 3-trifluoromethyl cyclopropene $\mathbf{4 h}$ was converted to quinoline $\mathbf{5 h}$ in $59 \%$ yield. The trifluoromethyl group is very popular in medicinal chemistry. ${ }^{21}$ Despite the attractiveness of such heterocycles, to the best of our knowledge, there are only two reported examples of the synthesis of 3-aryl, 4-trifluoromethylquinolines without the substituent at position 2 of the heterocyclic ring. ${ }^{22}$ Therefore, we focused on the synthesis of trifluoromethyl-substituted quinolines for further exploring the scope of the transformation. Different substituents on the aryl groups in 1 and 3 positions of the cyclopropenes were tolerated (products $\mathbf{5 i - 5 m}$ ), including electronrich, electron-poor and halogen substituents. 1-Alkyl-substituted cyclopropene $\mathbf{4 n}$ gave quinoline $\mathbf{5 n}$ in $34 \%$ yield. Interestingly, tetrasubstituted cyclopropenes 40 and $\mathbf{4 p}$ gave a single regioisomer of quinoline $\mathbf{5 0}$ and $\mathbf{5 p}$. This method can also be used for the synthesis of tetra- and pentasubstituted quinolines $\mathbf{5 q}$ and 5r. 1,2-Dialkylcyclopropenes were found to be inert to 
reaction conditions, representing a limitation of our methodology. Scale-up of the transformation was straightforward: $\mathbf{5 h}$ was obtained in $63 \%$ on a $1.5 \mathrm{mmol}$ scale.

Scheme 3. Substrate scope $\mathrm{a}^{\mathrm{a}}$

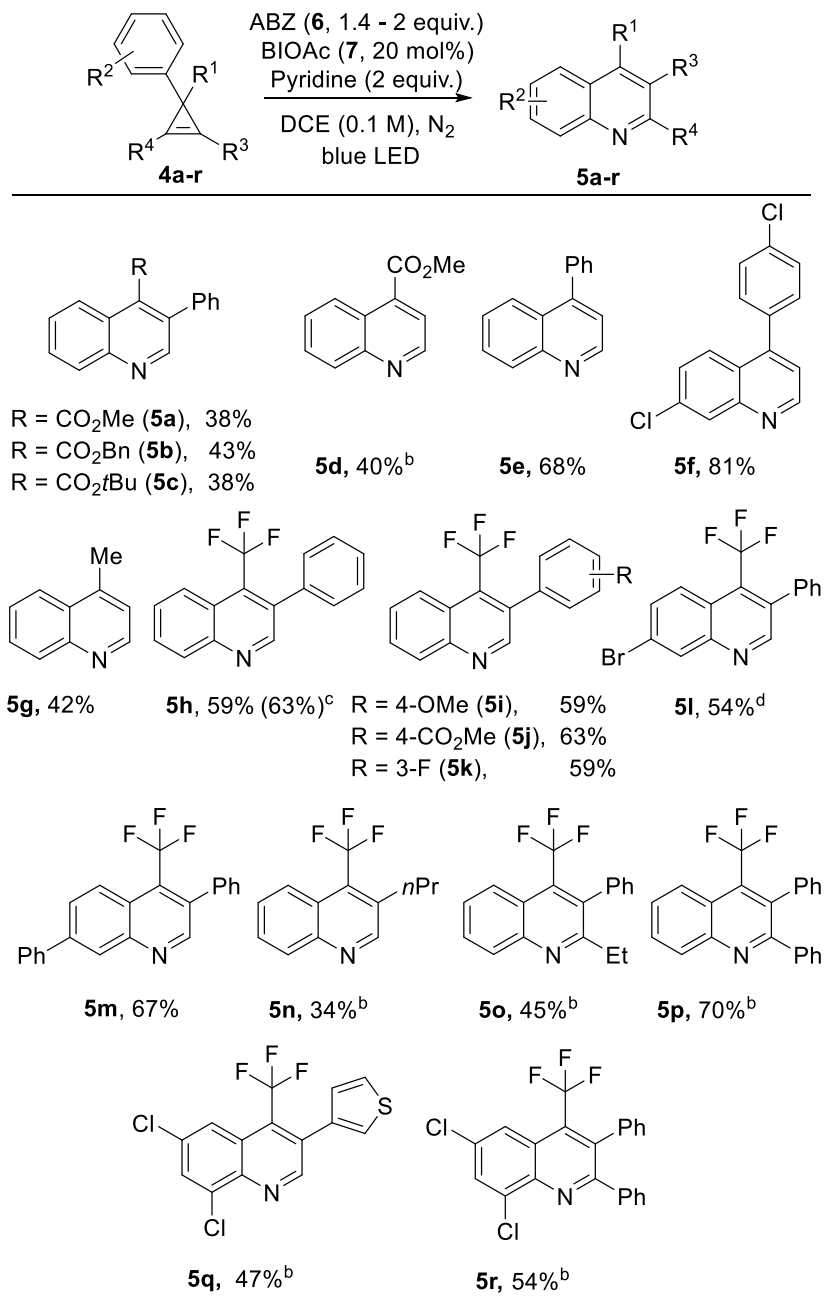

a Reaction conditions: $0.2 \mathrm{mmol}$ of cyclopropene, 1.4 equiv. ABZ (6), 2 equiv. of pyridine, $20 \mathrm{~mol} \%$ BIOAc (7), DCE (0.1 M), room temperature, $14 \mathrm{~h} .{ }^{\mathrm{b}}$ Reaction conditions: $0.2 \mathrm{mmol}$ of cyclopropene, 2 equiv. ABZ (6), 2 equiv. of pyridine, 20 mol\% BIOAc (7), DCE $(0.1 \mathrm{M})$, room temperature, 48 h. ${ }^{\mathrm{c}} 1.5 \mathrm{mmol}$ scale. ${ }^{\mathrm{d}} 0.1 \mathrm{mmol}$ scale.

Several experiments were then performed in order to get insight into the reaction mechanism (Scheme 4). It was found that the reaction does not proceed in the dark or under air (Eq. 1). Performing the reaction in the presence of TEMPO and BHT as radical scavengers fully inhibits the formation of the product $\mathbf{5 b}$ (Eq. 2). It was found that ABZ (6) slowly degrades under blue LED irradiation (Eq. 3), while the presence of BIOAc significantly accelerates this process (Eq. 4). Other control experiments showed that cyclopropene 2a as well as BIOAc (7) are stable when irradiated by blue LEDs as a solution in DCE.
Scheme 4. Control experiments<smiles>COC(=O)C1(c2ccccc2)C=C1c1ccccc1</smiles>
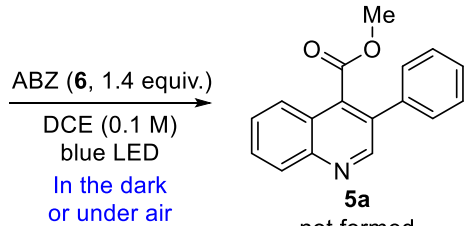<smiles>O=C(Oc1ccccc1)C1(c2ccccc2)C=C1c1ccccc1</smiles>

$A B Z(6,1.4$ equiv.) TEMPO (1.5 equiv.) $\stackrel{\text { or BHT ( } 1.5 \text { equiv. })}{\longrightarrow}$ DCE $(0.1 \mathrm{M})$ blue LED

not formed $\mathrm{Bn}$

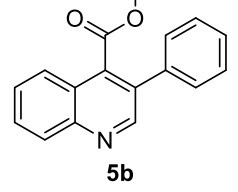<smiles></smiles>

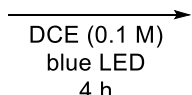

ABZ $(6)$

$\sim 65 \%$ recovered blue LED + degradation products

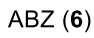

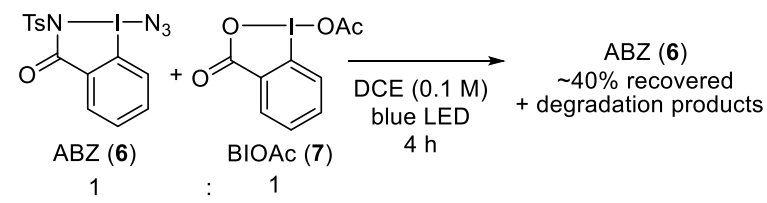

Based on these results and our previous investigations, ${ }^{5}$ we can suggest the following mechanism for the transformation (Scheme 5). Irradiation of ABZ (6) in presence of BIOAc (7) would result in the formation of an excited form, prone to homolytic cleavage of the weak $\mathrm{I}_{-} \mathrm{N}_{3}$ bond, forming an iodanyl radical I and an azidyl radical. Once formed, the azidyl radical would add to the cyclopropene double bond forming the reactive cyclopropyl radical II, which would undergo an electrocyclic ring-opening to give the $\alpha$-azidoallyl radical III. $\alpha$-azido radicals are known to quickly lose $\mathrm{N}_{2}$ forming the corresponding iminyl radicals $\mathbf{I V},{ }^{23}$ which could then cyclize to the adjacent arene ring giving rise to the intermediate V. Subsequent oxidation-deprotonation of $\mathbf{I V}$ with either iodanyl radical $\mathbf{I}$ or ABZ (6) would result in formation of product $\mathbf{2}$ and tosylamide 8. In the latter case, an azido radical would also be generated, leading to a chain process.

\section{Scheme 5. Mechanism proposal}

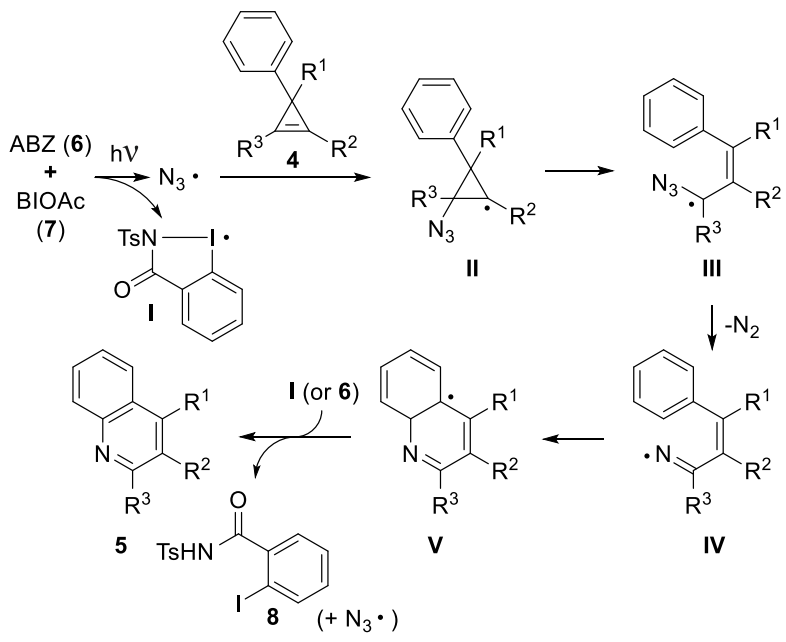


In summary, a protocol for the metal-free radical azidation of cyclopropenes leading to the formation of quinolines was developed. The hypervalent iodine reagent ABZ (6) was used as the source of azidyl radical under visible-light irradiation. The resulting transformation represents the first method for the synthesis of quinolines via the addition of a radical to a cyclopropene. The overall synthetic strategy is highly convergent as, starting from different alkynes and diazo compounds for accessing the cyclopropenes, multi-substituted quinolines can be obtained, especially valuable trifluoromethylated heterocycles. These results further demonstrate the potential of radical-based reactions with cyclopropenes as useful methods in organic synthesis.

\section{AUTHOR INFORMATION}

\section{Corresponding Author}

* jerome.waser@epfl.ch

\section{ACKNOWLEDGMENT}

We thank the Swiss National Science Foundation (Grant No. 200020_182798) for financial support.

\section{REFERENCES}

(1) a) Schleyer, P. von R.; Williams, J. E.; Blanchard K. R. Evaluation of Strain in Hydrocarbons. The Strain in Adamantane and Its Origin. $J$. Am. Chem. Soc. 1970, 92, 2377-2386. b) Bingham, R. C.; Dewar, M. J.; Lo, D. H. Ground States of Molecules. XXVI. MINDO/3 Calculations for Hydrocarbons. . J. Am. Chem. Soc. 1975, 97, 1294-1301.

(2) For selected reviews see: a) Dolbier, W. R.; Battiste, M. A. Structure, Synthesis, and Chemical Reactions of Fluorinated Cyclopropanes and Cyclopropenes. Chem. Rev. 2003, 103, 1071-1098. b) Nakamura, M.; Isobe, H.; Nakamura, E., Cyclopropenone Acetals - Synthesis and Reactions. Chem. Rev. 2003, 103, 1295-1326. c) Rubin, M.; Rubina, M.; Gevorgyan, V. Transition Metal Chemistry of Cyclopropenes and Cyclopropanes. Chem. Rev. 2007, 107, 3117-3179. d) Zhu, Z.-B.; Wei, Y.; Shi, M. Recent Developments of Cyclopropene Chemistry. Chem. Soc. Rev. 2011, 40, 5534-5563. e) Raiguru, B. P.; Nayak, S.; Mishra, D. R.; Das, T.; Mohapatra, S.; Mishra, N. P., Synthetic Applications of Cyclopropene and Cyclopropenone: Recent Progress and Developments. Asian J. Org. Chem. 2020, 9, 1088-1132. f) Li P., Zhang X., Shi M., Recent developments in cyclopropene chemistry. Chem. Commun. 2020, 56, 5457-5471. g) Vicente, R. C-C Bond Cleavages of Cyclopropenes: Operating for Selective Ring-Opening Reactions. Chem. Rev. 2021, 121, 162-226.

(3) Yamago, S.; Ejiri, S.; Nakamura, E. Hydrostannation of Cyclopropene. Strain-Driven Radical Addition Reaction. Chemistry letters 1994, 23, 1889-1892.

(4) a) Ferjančić, Z.; Čeković, Ž.; Saičić, R. N. Intermolecular Free Radical Additions to Strained Cycloalkenes. Cyclopropene and Cyclobutene as Radical Acceptors. Tetrahedron Lett. 2000, 41, 2979-2982. b) Legrand, N.; Quiclet-Sire, B.; Zard, S. Z. Radical Addition to Strained Olefins: A Flexible Access to Small Ring Derivatives. Tetrahedron Lett. 2000, 41, 9815-9818. c) Ueda, M.; Doi, N.; Miyagawa, H.; Sugita, S.; Takeda, N.; Shinada, T.; Miyata, O. Reaction of Cyclopropenes with a Trichloromethyl Radical: Unprecedented Ring-Opening Reaction of Cyclopropanes with Migration. Chem. Commun. 2015, 51, 4204-4207. d) Dange, N. S.; Robert, F.; Landais, Y. Free-Radical Carbocyanation of Cyclopropenes: Stereocontrolled Access to All-Carbon Quaternary Stereocenters in Acyclic Systems. Org. Lett. 2016, 18, 6156-6159. e) Dange, N. S.; Hussain Jatoi, A.; Robert, F.; Landais, Y. Visible-Light-Mediated Addition of Phenacyl Bromides onto Cyclopropenes. Org. Lett. 2017, 19, 3652-3655. f) Muriel, B.; Gagnebin, A.; Waser, J. Synthesis of Bicyclo[3.1.0]Hexanes by $(3+2)$ Annulation of Cyclopropenes with Aminocyclopropanes. Chem. Sci. 2019, 10, 10716-10722.
(5) Muriel, B.; Waser, J. Azide Radical Initiated Ring Opening of Cyclopropenes Leading to Alkenyl Nitriles and Polycyclic Aromatic Compounds. Angew. Chem. Int. Ed. 2021, 60, 4075-4079.

(6) Ebenso, E. E.; Obot, I. B.; Murulana, L. C. Quinoline and Its Derivatives as Effective Corrosion Inhibitors for Mild Steel in Acidic Medium. Int J Electrochem Sci 2010, 5, 1574-1586.

(7) (a) Liang, F.; Xie, Z.; Wang, L.; Jing, X.; Wang, F. New PPV Oligomers Containing 8-Substituted Quinoline for Light-Emitting Diodes. Tetrahedron Lett. 2002, 43, 3427-3430. (b) Jiang, P.; Zhu, W.; Gan, Z.; Huang, W.; Li, J.; Zeng, H.; Shi, J. Electron Transport Properties of an Ethanol-Soluble AlQ 3-Based Coordination Polymer and Its Applications in OLED Devices. J. Mater. Chem. 2009, 19, 4551-4556.

(8) Michael, J. P. Quinoline, Quinazoline and Acridone Alkaloids. Nat. prod. rep. 2008, 25, 166-187.

(9) a) Kaur, K.; Jain, M.; Reddy, R. P.; Jain, R. Quinolines and Structurally Related Heterocycles as Antimalarials. Eur. J. Med. Chem. 2010, 45, 3245-3264. b) Yernale, G. A Comprehensive Review on the Biological Interest of Quinoline and Its Derivatives. Bioorg. Med. Chem. 2021, 32, 115973.

(10) J.A. Joule; K.Mills. Quinolines and Isoquinolines: Reactions and Synthesis. In Heterocyclic Chemistry, $5^{\text {th }}$ Ed.; Wiley-Blackwell: Chichester, United Kingdom, 2010; pp 177-200.

(11) a) Teja, C.; Khan, F. R. N. Radical Transformations towards the Synthesis of Quinoline: A Review. Chem. Asian J. 2020, 15, 41534167. b) Dhiya, A. K.; Monga, A.; Sharma, A. Visible-Light-Mediated Synthesis of Quinolines. Org. Chem. Front. 2021, 8, 1657-1676.

(12) For a review, see: Walton, J. C. Synthetic Strategies for 5-and 6Membered Ring Azaheterocycles Facilitated by Iminyl Radicals. Molecules 2016, 21, 660 .

(13) a) Wang, W.-X.; Zhang, Q.-Z.; Zhang, T.-Q.; Li, Z.-S.; Zhang, W.; $\mathrm{Yu}, \mathrm{W}$. N-Bromosuccinimide-Mediated Radical Cyclization of 3-Arylallyl Azides: Synthesis of 3-Substituted Quinolines. Adv. Synth. Catal. 2015, 357, 221-226. b) Wang, Q.; Huang, J.; Zhou, L. Synthesis of Quinolines by Visible-Light Induced Radical Reaction of Vinyl Azides and A-Carbonyl Benzyl Bromides. Adv. Synth. Catal. 2015, 357, 2479-2484. c) Sun, X.; Yu, S. Visible-Light-Promoted Iminyl Radical Formation from Vinyl Azides: Synthesis of 6-(Fluoro) Alkylated Phenanthridines. Chem. Commun. 2016, 52, 10898-10901.

(14) Alazet, S.; Preindl, J.; Simonet-Davin, R.; Nicolai, S.; Nanchen, A.; Meyer, T.; Waser, J. Cyclic Hypervalent Iodine Reagents for Azidation: Safer Reagents and Photoredox-Catalyzed Ring Expansion. $J$. Org. Chem. 2018, 83, 12334-12356.

(15) Le Vaillant, F.; Garreau, M.; Nicolai, S.; Gryn'ova, G.; Corminboeuf, C.; Waser, J. Fine-Tuned Organic Photoredox Catalysts for Fragmentation-Alkynylation Cascades of Cyclic Oxime Ethers. Chem. Sci. 2018, 9, 5883-5889.

(16) Luo, J.; Zhang, J. Donor-Acceptor Fluorophores for VisibleLight-Promoted Organic Synthesis: Photoredox/Ni Dual Catalytic C (Sp3)-C (Sp2) Cross-Coupling. ACS Catal. 2016, 6, 873-877.

(17) For the use of BIOAc as an additive, see: a) Amos, S. G.; Nicolai, S.; Waser, J. Photocatalytic Umpolung of N-and O-Substituted Alkenes for the Synthesis of 1, 2-Amino Alcohols and Diols. Chem. Sci. 2020, 11, 11274-11279. b) Huang, H.; Jia, K.; Chen, Y. Hypervalent Iodine Reagents Enable Chemoselective Deboronative/Decarboxylative Alkenylation by Photoredox Catalysis. Angew. Chem. Int. Ed 2015, 54 , 1881-1884.

(18) Petiniot, N.; Anciaux, A. J.; Noels, A. F.; Hubert, A. J.; Teyssié, P. Rhodium Catalysed Cyclopropenation of Acetylenes. Tetrahedron Lett. 1978, 19, 1239-1242.

(19) Briones, J. F.; Davies, H. M. Silver Triflate-Catalyzed Cyclopropenation of Internal Alkynes with Donor-/Acceptor-Substituted Diazo Compounds. Org. Lett. 2011, 13, 3984-3987.

(20) Rubin, M.; Gevorgyan, V. Simple Large-Scale Preparation of 3, 3-Disubstituted Cyclopropenes: Easy Access to Stereodefined Cyclopropylmetals via Transition Metal-Catalyzed Hydrometalation. Synthesis 2004, 2004, 796-800.

(21) a) Zanda, M. Trifluoromethyl Group: An Effective Xenobiotic Function for Peptide Backbone Modification. New J. Chem. 2004, 28 , 1401-1411. b) Jäckel, C.; Koksch, B. Fluorine in Peptide Design and Protein Engineering. Eur. J. Org. Chem. 2005, 2005, 4483-4503. c) 
Isanbor, C.; O'Hagan, D. Fluorine in Medicinal Chemistry: A Review of Anti-Cancer Agents. J. Fluor. Chem. 2006, 127, 303-319.

(22) a) Du, X. L.; Jiang, B.; Li, Y. C. Proline Potassium Salt: A Superior Catalyst to Synthesize 4-Trifluoromethyl Quinoline Derivatives via Friedlander Annulation. Tetrahedron 2013, 69, 7481-7486. b) Nagase, M.; Kuninobu, Y.; Kanai, M. 4-Position-Selective C-H Perfluoroalkylation and Perfluoroarylation of Six-Membered Heteroaromatic Compounds. J. Am. Chem. Soc. 2016, 138, 6103-6106.
(23) (a) A. Suzuki, M. Tabata and M. Ueda, Tetrahedron Lett., 1975, 16, 2195-2198; (b) A. F. Bamford, M. D. Cook and B. P. Roberts, Tetrahedron Lett., 1983, 24, 3779-3782; (c) P. C. Montevecchi, M. L. Navacchia and P. Spagnolo, J. Org. Chem., 1997, 62, 5846-5848; (d) Y.-F. Wang, K. K. Toh, S. Chiba and K. Narasaka, Org. Lett., 2008, 10, 5019-5022; (e) E. P. J. Ng, Y.-F. Wang and S. Chiba, Synlett, 2011, $783-786$. 


\section{Supporting information}

\section{Synthesis of quinolines via metal-free visible-light-mediated radical azidation of cyclopropenes}

Vladyslav Smyrnov, Bastian Muriel, Jerome Waser

Laboratory of Catalysis and Organic Synthesis, Institut des Sciences et Ingénierie Chimique, Ecole Polytechnique Fédérale de Lausanne, Lausanne, Switzerland 


\section{Table of Contents}

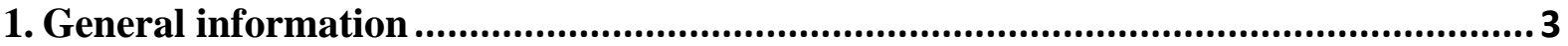

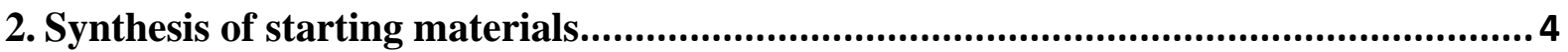

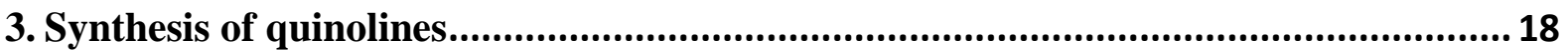

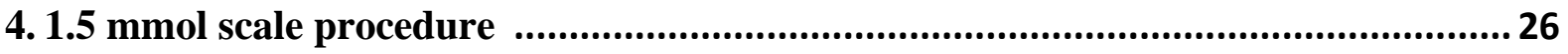

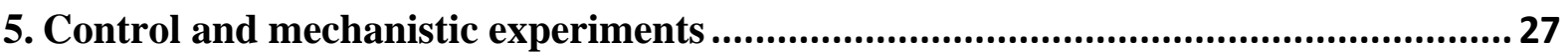

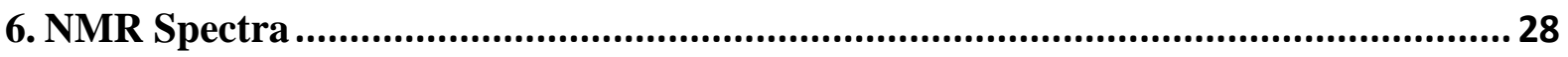




\section{General information}

HPLC grade or technical grade solvents were used for flash chromatography. For non-airsensitive reactions, analytical or reagent grade solvents purchased from Merck or SigmaAldrich were used unless specified. THF, $\mathrm{Et}_{2} \mathrm{O}, \mathrm{CH}_{3} \mathrm{CN}$, toluene, hexane and $\mathrm{CH}_{2} \mathrm{Cl}_{2}$ were dried by passage over activated alumina under nitrogen atmosphere $\left(\mathrm{H}_{2} \mathrm{O}\right.$ content $<10 \mathrm{ppm}$, Karl-Fischer titration). Solvents were degassed by bubbling with a balloon of argon when mentioned. Reagents were purchased from Sigma-Aldrich, Acros, TCI, Fluorochem, Fluka, VWR or Merck, unless specified. Chromatographic purification was performed as flash chromatography using Silicycle silica 40-63, $60 \AA$, using the solvents indicated as eluent with 0.1-0.5 bar pressure or using Biotage Isolera Spektra One with pre-packaged silica cartridges purchased from Buchi, models: Sepacore or GraceResolve (4 g, 12 g, 25 g, 40g, 80g, 120g). TLC was performed on Merck silica gel 60 F254 TLC glass plates or aluminium plates and visualized with UV light, permanganate stain, p-anisaldehyde stain. ${ }^{1} \mathrm{H}$ NMR spectra were recorded on a Brucker DPX-400, $400 \mathrm{MHz}$, in chloroform-d, DMSO-d6 and $\mathrm{CD}_{3} \mathrm{CN}$. All signals are reported in ppm using the residual solvent signal as internal reference (chloroformd: $7.26 \mathrm{ppm}$, DMSO-d6: $2.50 \mathrm{ppm}, \mathrm{CD}_{3} \mathrm{CN}: 1.96 \mathrm{ppm}$ ). The data is reported as (multiplicity, coupling constants in $\mathrm{Hz}$, integration, interpretation) using these abbreviations: $\mathrm{s}=$ singlet, $\mathrm{d}=$ doublet, $\mathrm{t}=$ triplet, $\mathrm{m}=$ multiplet, $\mathrm{bs}=$ broad signal. ${ }^{13} \mathrm{C}$ NMR spectra were carried out with $1 \mathrm{H}$ decoupling on a Brucker DPX-400, $101 \mathrm{MHz}$. All signals are reported in ppm using the residual solvent signal as internal reference (chloroform-d: $77.0 \mathrm{ppm}$ or DMSO-d6: $39.5 \mathrm{ppm}$ ). Infrared spectra were obtained on a JASCO FT-IR B4100 spectrophotometer with an ATR PRO410-S and a ZnSe prisma and are reported in $\mathrm{cm}-1$ as ( $\mathrm{w}=$ weak, $\mathrm{m}=$ medium, $\mathrm{s}=$ strong). High resolution mass spectrometric measurements were performed by the mass spectrometry service of ISIC at the EPFL. Electrospray-ionisation HRMS data were acquired on a Q-Tof Ultima mass spectrometer (Waters) or a Q-Tof 6530 Accurate mass spectrometer (Agilent) operated in the positive ionization mode and fitted with a standard Z-spray ion source equipped with the Lock-Spray interface. Data from the Lock-Spray were used to calculate a correction factor for the mass scale and provide accurate mass information of the analyte. Data were processed using the MassLynx 4.1 software. Atmospheric pressure photo-ionisation (APPI) HRMS measurements were done on a LTQOrbitrap Elite instrument (Thermofisher) operated in the positive ionization mode. Reactions under blue LED irradiation were performed in test tubes $(1.0$ to $10 \mathrm{~mL})$ which were hold using a rack for test-tubes placed at the centre of a crystallization flask. On this flask were attached the blue LEDs (RUBAN LED 5MÈTRES60LED/M-3528BLEU-IP65 with Transformateur pour Ruban LED 24W/2A/12V, bought directly on RubanLED.com). The distance between the LEDs and the test tubes was approximatively $5 \mathrm{~cm}$. Long irradiation resulted in temperature increasing up to $35^{\circ} \mathrm{C}$ during overnight reactions. 


\section{Synthesis of starting materials}

\subsection{Synthesis of azidating reagent (ABZ)}

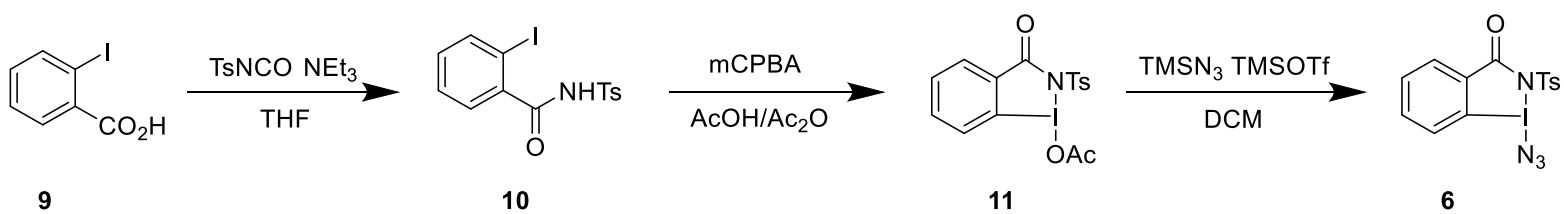

1-Azido-2-tosyl-1,2-dihydro-3H-1ג3-benzo[d][1,2]iodazol-3-one(ABZ)(6)

Following a modified reported procedure ${ }^{1}$, to a solution of 2-iodobenzoic acid (9) (10.0 g, 40.3 mmol, 1.00 equiv) and tosyl isocyanate $(7.95 \mathrm{~g}, 40.3 \mathrm{mmol}, 1.00$ equiv) in THF (115 mL) $\mathrm{NEt}_{3}(4.08 \mathrm{~g}, 40.3 \mathrm{mmol}, 1.00$ equiv) was added dropwise. The reaction mixture was stirred at r.t. for $2 \mathrm{~h}$. The reaction mixture was diluted with $\operatorname{EtOAc}(175 \mathrm{ml})$ and washed with $\mathrm{HCl}(1 \mathrm{~N})$ $(2 \times 70 \mathrm{ml})$ and brine $(100 \mathrm{ml})$. The organic layer was dried over $\mathrm{MgSO}_{4}$, filtered and concentrated under vacuum to give 2-iodo-N-(4-methylphenyl)sulfonylbenzamide(10) $(17.8 \mathrm{~g}, 90 \%$ purity, 39.9 mmol, $99 \%$ yield) as a yellow thick oil. The compound was used without further purification.

${ }^{1} \mathrm{H}$ NMR $\left(400 \mathrm{MHz}, \mathrm{CDCl}_{3}\right) \delta 8.78(\mathrm{~s}, 1 \mathrm{H}, \mathrm{NH}), 8.01(\mathrm{~d}, J=8.4 \mathrm{~Hz}, 2 \mathrm{H}, \mathrm{Ar} H), 7.80(\mathrm{dd}, J=$ 8.0, 1.0 Hz, 1H, ArH), 7.43-7.31 (m, 4H, ArH), 7.10 (ddd, $J=8.0,7.2,2.0 \mathrm{~Hz}, 1 \mathrm{H}, \mathrm{ArH}), 2.44$ $\left(\mathrm{s}, 3 \mathrm{H}, \mathrm{ArCH}_{3}\right) \mathrm{ppm}$. Spectral data of the obtained compound is corresponding to the reported values ${ }^{1}$.

A solution of 2-iodo-N-(4-methylphenyl)sulfonylbenzamide(10) (17.8 g, $44.5 \mathrm{mmol}, 1.00$ equiv) and 3-chloroperbenzoic acid acid (9.97 g, $44.5 \mathrm{mmol}$, 1equiv, ca $75 \%$ purity) in acetic acid $(150 \mathrm{~mL})$ and acetic anhydride $(150 \mathrm{~mL})$ was heated at $80^{\circ} \mathrm{C}$ for $72 \mathrm{~h}$. The reaction mixture was diluted with ether $(140 \mathrm{ml})$, cooled to $-20^{\circ} \mathrm{C}$. The formed solid was filtered off, washed with ether and dried under vacuum to give 3-oxo-2-tosyl-2,3-dihydro- $1 H$-1 $\lambda 3$ benzo[d][1,2]iodazol-1-yl acetate $(\mathbf{1 1})(9.00 \mathrm{~g}, 95 \%$ purity, $19.6 \mathrm{mmol}, 44 \%$ yield $)$ as a white solid. The compound was used without further purification.

${ }^{1} \mathrm{H}$ NMR (400 MHz, d6-DMSO) $\delta 8.02-7.95$ (m, 2H, ArH), 7.95-7.89 (m, 2H, ArH), 7.86 (dd, $J=8.8,0.9 \mathrm{~Hz}, 1 \mathrm{H}, \operatorname{Ar} H), 7.80-7.71(\mathrm{~m}, 1 \mathrm{H}, \operatorname{Ar} H), 7.44(\mathrm{~d}, J=8.1 \mathrm{~Hz}, 2 \mathrm{H}, \operatorname{Ar} H), 2.38(\mathrm{~s}$, $\left.3 \mathrm{H}, \mathrm{ArCH}_{3}\right), 2.26\left(\mathrm{~s}, 3 \mathrm{H}, \mathrm{COCH}_{3}\right) \mathrm{ppm}$. Spectral data of the obtained compound is corresponding to the reported values ${ }^{1}$.

Caution: For safety reasons, the reaction was carried out behind an antiblast shield. To a solution of 11 (2.76 g, $6.00 \mathrm{mmol}, 1.00$ equiv) in dichloromethane $(30.0 \mathrm{~mL})$, cooled to $0^{\circ} \mathrm{C}$ azido(trimethyl)silane ( $1.04 \mathrm{~g}, 9.00 \mathrm{mmol}, 1.50$ equiv) was added dropwise, followed by 1 drop of trimethylsilyl trifluoromethanesulfonate $(6.67 \mathrm{mg}, 30.0 \mu \mathrm{mol}, 0.00500$ equiv). The reaction mixture was stirred at $20^{\circ} \mathrm{C}$ for 60 minutes, then cooled back to $0^{\circ} \mathrm{C}$. The reaction mixture was dilutedwith cold pentane $(12 \mathrm{ml})$, stirred for 5 minutes, then filtered. The precipitate was washed with cold pentane $(10 \mathrm{ml})$ and dried on the frite to give ABZ (6) $(2.05 \mathrm{~g}, 4.61 \mathrm{mmol}, 77 \%$ yield) as a light-yellow solid. ${ }^{1} \mathrm{H}$ NMR (400 MHz, d6-DMSO) $\delta 8.17(\mathrm{dd}, J=8.3,0.9 \mathrm{~Hz}, 1 \mathrm{H}, \operatorname{Ar} H$ ), 8.03-7.93 (m, 2H, ArH), 7.93-7.87 (m, 2H, ArH), $7.75(\mathrm{td}, J=7.4,0.9 \mathrm{~Hz}, 1 \mathrm{H}, \operatorname{ArH})$, 7.46-7.37 (m, 2H, $\mathrm{ArH}), 2.38\left(\mathrm{~s}, 3 \mathrm{H}, \mathrm{ArCH}_{3}\right) \mathrm{ppm}$. Spectral data of the obtained compound is corresponding to the reported values ${ }^{1}$.

\subsection{Synthesis of diazo compounds}

\footnotetext{
${ }^{1}$ Alazet, S.; Preindl, J.; Simonet-Davin, R.; Nicolai, S.; Nanchen, A.; Meyer, T.; Waser, J., J. Org. Chem. 2018, 83 (19), 12334-12356.
} 


\section{Benzyl 2-phenylacetate (13)}

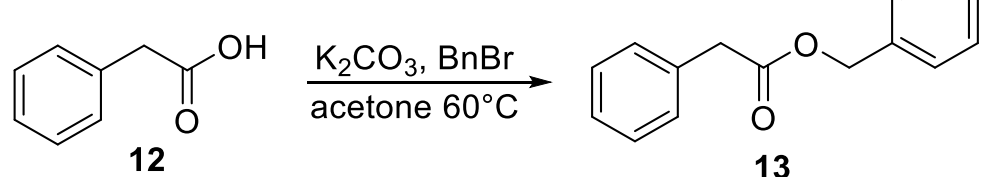

Following a reported procedure ${ }^{2}$, a solution of 2-phenylacetic acid(12) (3.00 g, 22.0 mmol, 1.00 equiv), potassium carbonate (3.35 g, $24.2 \mathrm{mmol}, 1.10$ equiv) and bromomethylbenzene (4.52 g, $26.4 \mathrm{mmol}, 1.20$ equiv) in acetone $(45.0 \mathrm{~mL})$ was heated at reflux overnight. The reaction mixture was concentrated under vacuum, diluted with water $(60 \mathrm{ml})$ and extracted with $\operatorname{DCM}(260 \mathrm{ml})$. The organic layer was dried over $\mathrm{Na}_{2} \mathrm{SO}_{4}$, filtered and concentrated under vacuum to give benzyl 2-phenylacetate (13) (5.47g, 90\% purity, $21.8 \mathrm{mmol}$, 99\% yield) which was used without further purification.

${ }^{1} \mathrm{H}$ NMR (400 MHz, CDCl 3 ) $\delta 7.40-7.28$ (m, 10H, $\left.\mathrm{ArH}\right), 5.15$ (s, 2H, $\mathrm{PhCH}_{2} \mathrm{O}$ ), 3.68 (s, 2H, $\left.\mathrm{C}(\mathrm{O}) \mathrm{CH}_{2} \mathrm{Ph}\right)$. Spectral data of the obtained compound is corresponding to the reported values ${ }^{2}$.

Tert-butyl 2-phenylacetate (14)

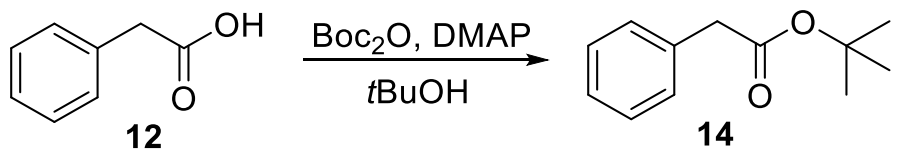

Following a reported procedure ${ }^{3}$, a solution of 2-phenylacetic acid $(1.00 \mathrm{~g}, 7.34 \mathrm{mmol}, 1.00$ equiv), tert-butyl (2-methylpropan-2-yl)oxycarbonyl carbonate (3.37 g, $15.4 \mathrm{mmol}, 2.10$ equiv) and $\mathrm{N}, \mathrm{N}$-dimethylpyridin-4-amine (269 $\mathrm{mg}, 2.20 \mathrm{mmol}, 0.300$ equiv) in 2methylpropan-2-ol $(20.0 \mathrm{~mL})$ was heated at $30^{\circ} \mathrm{C}$ overnight. The reaction mixture was concentrated under vacuum to give crude tert-butyl 2-phenylacetate (14) (950 mg, 90\% purity, $4.94 \mathrm{mmol}, 67 \%$ yield), which was used without further purification.

${ }^{1} \mathrm{H}$ NMR (400 MHz, $\left.\mathrm{CDCl}_{3}\right) \delta 7.46-7.15$ (m, 5H, $\left.\mathrm{ArH}\right), 3.53$ (s, 2H, CHz), 1.44 (s, 9H, CH3). Spectral data of the obtained compound is corresponding to the reported values ${ }^{3}$.

\section{General procedure for the preparation of diazo compounds(GP1)}<smiles>[R]OC(=O)Cc1ccccc1</smiles>

Following a reported procedure ${ }^{4}$, DBU (1.6 equiv.) and the indicated $\alpha$-arylacetate (1.0 equiv.) were added to a solution of pABSA (1.5 equiv.) in $\mathrm{CH}_{3} \mathrm{CN}(0.5 \mathrm{M})$ at room temperature and the resulting mixture was stirred for 18 hours. The reaction mixture was then diluted with distilled water and extracted with diethyl ether. The combined organic layers were washed with a $10 \% \mathrm{NaHCO}_{3}$ solution and brine, then dried over $\mathrm{MgSO}_{4}$, filtered, and concentrated under reduced pressure. The crude residue was purified by column chromatography with the indicated solvents.

\footnotetext{
${ }^{2}$ Chapman, R. S.; Francis, M.; Lawrence, R.; Tibbetts, J. D.; Bull, S. D., Tetrahedron 2018, 74 (44), 6442-6452.

${ }^{3}$ Gao, M.; Zhao, Y.; Zhong, C.; Liu, S.; Liu, P.; Yin, Q.; Hu, L., Org. Lett. 2019, 21 (14), 5679-5684.

${ }^{4}$ B. Muriel, J. Waser, Angew. Chem. Int. Ed. 2021, 60, 4075-4079.
} 
Methyl 2-diazo-2-phenylacetate (15)<smiles>COC(=O)C(=N)c1ccccc1</smiles>

Following the GP1, starting from methyl 2-phenylacetate $(5.00 \mathrm{~g}, 33.2 \mathrm{mmol})$, the title compound 15 was obtained after purification by flash column chromatography $\left(\mathrm{SiO}_{2}\right.$, $\mathrm{Et}_{2} \mathrm{O} /$ Pentane $2 / 98$ to $\left.10 / 90\right)$ as a red oil (4.25 g, $24.1 \mathrm{mmol}, 72 \%$ yield). $\mathrm{Rf}=0.36$ $\left(\mathrm{Et}_{2} \mathrm{O}\right.$ :Pentane 1:20).

${ }^{1} \mathrm{H}$ NMR $\left(400 \mathrm{MHz}, \mathrm{CDCl}_{3}\right): \delta$ 7.52-7.45 (m, 2H, $\left.\mathrm{ArH}\right), 7.42-7.34(\mathrm{~m}, 2 \mathrm{H}, \mathrm{ArH}), 7.19(\mathrm{td}, J$ $=7.3,1.2 \mathrm{~Hz}, 1 \mathrm{H}, \mathrm{ArH}), 3.87\left(\mathrm{~s}, 3 \mathrm{H}, \mathrm{OCH}_{3}\right)$. Spectral data of the obtained compound is corresponding to the reported values ${ }^{4}$.

Benzyl 2-diazo-2-phenylacetate (16)<smiles>N#CC(=O)OCc1ccccc1</smiles>

Following the GP1, starting from benzyl 2-phenylacetate (13) $(5.47 \mathrm{~g}, 24.1 \mathrm{mmol})$, the title compound 16 was obtained after purification by flash column chromatography $\left(\mathrm{SiO}_{2}\right.$, $\mathrm{Et}_{2} \mathrm{O} /$ Pentane $2 / 98$ to $10 / 90$ ) as an orange solid (4.70 g, $18.6 \mathrm{mmol}, 77 \%$ yield). $\mathrm{Rf}=0.47$ (EtOAc:Pentane 10:90).

${ }^{1} \mathrm{H}$ NMR (400 MHz; $\left.\mathrm{CDCl}_{3}\right): \delta 7.48(\mathrm{dd}, J=8.5,1.1 \mathrm{~Hz}, 2 \mathrm{H}, \mathrm{Ar} H), 7.41-7.32(\mathrm{~m}, 7 \mathrm{H}, \mathrm{Ar} H)$, $7.17(\mathrm{t}, J=7.4 \mathrm{~Hz}, 1 \mathrm{H}, \mathrm{ArH}), 5.30\left(\mathrm{~s}, 2 \mathrm{H}, \mathrm{CH}_{2}\right)$. Spectral data of the obtained compound is corresponding to the reported values ${ }^{5}$.

\section{Tert-butyl 2-diazo-2-phenylacetate (17)}<smiles>CC(C)(C)OC(=O)C(=[W])c1ccccc1</smiles>

17

Following the GP1, starting from tert-butyl 2-phenylacetate (14) (950mg, $4.94 \mathrm{mmol})$, the title compound 17 was obtained after purification by flash column chromatography $\left(\mathrm{SiO}_{2}\right.$, EtOAc/Pentane 2/98 to 10/90) as an orange oil (530 mg, $2.43 \mathrm{mmol}, 49 \%$ yield). $\mathrm{Rf}=0.5$ (Et${ }_{2} \mathrm{O}:$ Pentane 1:8). ${ }^{1} \mathrm{H}$ NMR (400 MHz, Chloroform-d) $\delta 7.44-7.37$ (m, 2H, ArH), $7.37-7.32$ $(\mathrm{m}, 2 \mathrm{H}, \mathrm{ArH}), 7.21-7.13(\mathrm{~m}, 1 \mathrm{H}, \mathrm{ArH}), 1.55\left(\mathrm{~s}, 9 \mathrm{H}, \mathrm{CH}_{3}\right)$. Spectral data of the obtained compound is corresponding to the reported values ${ }^{4}$.

(1-Diazo-2,2,2-trifluoroethyl)benzene (20)

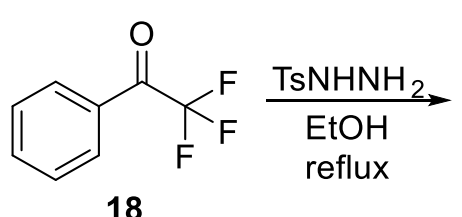<smiles>[15NH]N/N=C(/c1ccccc1)C(F)(F)F</smiles>

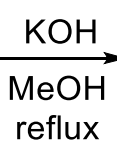

reflux<smiles>N#CC(F)(F)c1ccccc1</smiles>

20

\footnotetext{
${ }^{5}$ Ye, F.; Qu, S.; Zhou, L.; Peng, C.; Wang, C.; Cheng, J.; Hossain, M. L.; Liu, Y.; Zhang, Y.; Wang, Z.-X., J. Am. Chem. Soc. 2015, 137 (13), 4435-4444.
} 
Following a reported procedure ${ }^{6}$, a solution of 2,2,2-trifluoro-1-phenylethanone (18) $(35.17 \mathrm{~g}$, $202.0 \mathrm{mmol}, 1.00$ equiv) and 4-methylbenzenesulfonohydrazide (37.62 g, $202.0 \mathrm{mmol}, 1.00$ equiv) in ethanol $(400 \mathrm{~mL})$ was heated at reflux for $14 \mathrm{~h}$. The reaction mixture was cooled to r.t., concentrated under vacuum. The resulting crude was triturated with pentane $(200 \mathrm{ml})$, filtered. The precipitate was washed with pentane and dried under vacuum to give $\mathrm{N}-[(\mathrm{E})-(2,2-$ dimethyl-1-phenylpropylidene)amino]-4-methylbenzenesulfonamide (19) (28.3 g, $85.6 \mathrm{mmol}$, $42 \%$ yield) as a white solid(95\% purity), which was used without further purification.

${ }^{1} \mathrm{H}$ NMR (400 MHz, $\left.\mathrm{CDCl}_{3}\right) \delta 7.95(\mathrm{~s}, 1 \mathrm{H}, \mathrm{NH}), 7.82(\mathrm{~d}, J=8.4 \mathrm{~Hz}, 2 \mathrm{H}, \mathrm{ArH}), 7.57-7.50$ $(\mathrm{m}, 3 \mathrm{H}, \operatorname{Ar} H), 7.36(\mathrm{~d}, J=8.1 \mathrm{~Hz}, 2 \mathrm{H}, \operatorname{Ar} H), 7.27-7.22(\mathrm{~m}, 2 \mathrm{H}, \mathrm{ArH}), 2.46\left(\mathrm{~s}, 3 \mathrm{H}, \mathrm{CH}_{3}\right)$. Spectral data of the obtained compound is corresponding to the reported values ${ }^{4}$.

Following a reported procedure ${ }^{7}, \mathrm{KOH}(10.19 \mathrm{~g}, 181.6 \mathrm{mmol}, 2.000$ equiv.) was dissolved in $\mathrm{MeOH}(270 \mathrm{~mL})$ by stirring at room temperature. 4-Methyl-N'-(2,2,2-trifluoro-1phenylethylidene)benzenesulfonohydrazide (19) (31.1 g, $90.7 \mathrm{mmol})$ was added in one portion and the solution was heated to reflux for $\sim 1 \mathrm{~h}$ and then cooled to room temperature. Water (300 $\mathrm{mL})$ was added and the resulting mixture was extracted with pentane $(3 \times 150 \mathrm{~mL})$. The combined organic layers were dried over $\mathrm{MgSO}_{4}$, filtered and concentrated under low vacuum (900 mbar, $40{ }^{\circ} \mathrm{C}$ ) until no more pentane condensed to give (1-diazo-2,2,2trifluoroethyl)benzene (20) (30.6 mmol, $34 \%$ yield) as a $1.3 \mathrm{M}$ solution in pentane (concentration was measured by ${ }^{19} \mathrm{~F}$ NMR using $\mathrm{PhCF}_{3}$ as an internal standard). The solution was stored at $-20^{\circ} \mathrm{C}$ and used for the next reactions as such.

${ }^{1} \mathrm{H}$ NMR (400 MHz, $\left.\mathrm{CDCl}_{3}\right) \delta 7.46-7.38(\mathrm{~m}, 2 \mathrm{H}, \mathrm{ArH}), 7.25-7.19(\mathrm{~m}, 1 \mathrm{H}, \mathrm{ArH}), 7.17-$ $7.08(\mathrm{~m}, 2 \mathrm{H}, \mathrm{ArH})$. Spectral data of the obtained compound is corresponding to the reported values ${ }^{4}$.

\section{1,3-Dichloro-5-(1-diazo-2,2,2-trifluoroethyl)benzene (23)}

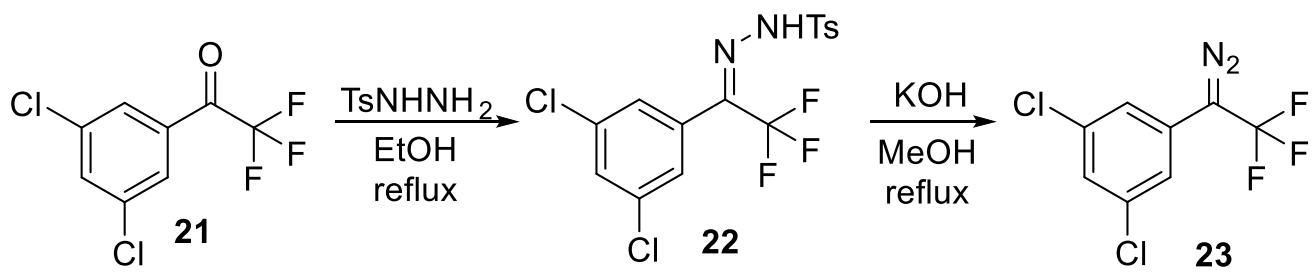

A solution of 1-(3,5-dichlorophenyl)-2,2,2-trifluoroethan-1-one (21) (3.75 g, $15.4 \mathrm{mmol}, 1.00$ equiv) and 4-methylbenzenesulfonohydrazide ( $2.87 \mathrm{~g}, 15.4 \mathrm{mmol}, 1.00 \mathrm{equiv})$ in toluene (15 $\mathrm{mL}$ ) was heated at $90{ }^{\circ} \mathrm{C}$ for $14 \mathrm{~h}$. The mixture was cooled to r.t. and filtered. The precipitate was washed with pentane and dried under vacuum to give $\mathrm{N}^{\prime}$-(1-(3,5-dichlorophenyl)-2,2,2trifluoroethylidene)-4-methylbenzenesulfonohydrazide (22) as an off-white solid (3.81 g, 9.27 mmol, $60 \%$ yield).

$\mathrm{Rf}=0.43$ (EtOAc:Pentane 1:9). ${ }^{1} \mathrm{H}$ NMR $\left(400 \mathrm{MHz}, \mathrm{CDCl}_{3}\right) \delta 8.03(\mathrm{~s}, 1 \mathrm{H}, \mathrm{NH}), 7.85-7.77$ $(\mathrm{m}, 2 \mathrm{H}, \operatorname{Ar} H), 7.53(\mathrm{t}, J=1.9 \mathrm{~Hz}, 1 \mathrm{H}, \operatorname{Ar} H), 7.37(\mathrm{~d}, J=8.1 \mathrm{~Hz}, 2 \mathrm{H}, \operatorname{Ar} H), 7.13(\mathrm{~d}, J=1.9$ $\mathrm{Hz}, 2 \mathrm{H}, \mathrm{ArH}), 2.47$ (s, 3H, CH3). ${ }^{13} \mathrm{C} \mathrm{NMR}\left(101 \mathrm{MHz}, \mathrm{CDCl}_{3}\right) \delta 145.4,138.1(\mathrm{q}, J=36.4 \mathrm{~Hz})$, 137.1, 134.1, 131.9, 130.0, 128.1, 127.9, 126.7, 119.6 (q, $J=275.0 \mathrm{~Hz}), 21.7 .{ }^{19} \mathrm{~F}$ NMR $(376$ $\left.\mathrm{MHz}, \mathrm{CDCl}_{3}\right) \delta$-68.0. HRMS (nanochip-ESI/LTQ-Orbitrap) $\mathrm{m} / \mathrm{z}:[\mathrm{M}+\mathrm{Na}]^{+} \mathrm{Calcd}$ for $\mathrm{C}_{15} \mathrm{H}_{11} \mathrm{Cl}_{2} \mathrm{~F}_{3} \mathrm{~N}_{2} \mathrm{NaO}_{2} \mathrm{~S}^{+}$432.9763; Found 432.9753. M.p. $173-175^{\circ} \mathrm{C}$.

\footnotetext{
${ }^{6}$ Liang, X.; Guo, P.; Yang, W.; Li, M.; Jiang, C.; Sun, W.; Loh, T.-P.; Jiang, Y. Chem. Commun. 2020, 56 (13), $2043-$ 2046.

${ }^{7}$ Denton, J. R.; Sukumaran, D.; Davies, H. M., Org. Lett. 2007, 9 (14), 2625-2628.
} 
$\mathrm{KOH}$ (1.01 g, $18.0 \mathrm{mmol}, 2.00$ equiv) was dissolved in $\mathrm{MeOH}(40 \mathrm{~mL})$ by stirring at room temperature. 4-Methyl-N'-(2,2,2-trifluoro-1-phenylethylidene)benzenesulfonohydrazide (22) $(3.71 \mathrm{~g}, 9.02 \mathrm{mmol}, 1.00$ equiv) was added in one portion and the solution was heated to reflux for $\sim 1 \mathrm{~h}$ and then cooled to room temperature. Water $(100 \mathrm{~mL})$ was added and the resulting mixture was extracted with pentane $(3 \times 50 \mathrm{~mL})$. The combined organic layers were dried over $\mathrm{MgSO}_{4}$, filtered and concentrated under vacuum to give 1,3-dichloro-5-(1-diazo-2,2,2trifluoroethyl)benzene (23) as a red oil ((780 $\mathrm{mg}, 3.06 \mathrm{mmol}, 34 \%$ yield $)$.

$\mathrm{Rf}=0.83$ (pentane). ${ }^{1} \mathrm{H}$ NMR $\left(400 \mathrm{MHz}, \mathrm{CDCl}_{3}\right) \delta 7.18(\mathrm{t}, J=1.8 \mathrm{~Hz}, 1 \mathrm{H}, \mathrm{ArH}), 6.95(\mathrm{~d}, J=$ $1.7 \mathrm{~Hz}, 2 \mathrm{H}, \mathrm{Ar} H) .{ }^{13} \mathrm{C} \mathrm{NMR}\left(101 \mathrm{MHz}, \mathrm{CDCl}_{3}\right) \delta 136.2,127.4,125.8,124.8(\mathrm{q}, J=269.9 \mathrm{~Hz})$, 120.0 (one carbon is not resolved). ${ }^{19} \mathrm{~F}$ NMR $\left(376 \mathrm{MHz}, \mathrm{CDCl}_{3}\right) \delta-57.3$.

\section{1-Bromo-4-(1-diazo-2,2,2-trifluoroethyl)benzene (26)}

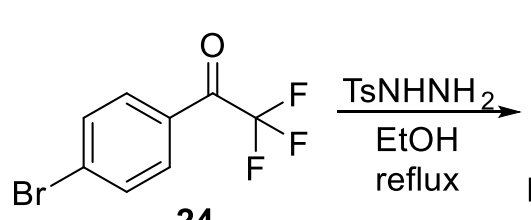

24<smiles>FC(F)(F)/C(=N\N[Sb])c1ccc(Br)cc1</smiles>

25<smiles>N#CC(F)(F)C(=N)c1ccc(Br)cc1</smiles>

26

Following a reported procedure ${ }^{8}, 1$-(4-bromophenyl)-2,2,2-trifluoroethanone (24) $(633 \mathrm{mg}$, $2.50 \mathrm{mmol}, 1.05$ equiv.) was added to $\mathrm{EtOH}(4.7 \mathrm{~mL})$ at room temperature followed by $p$ toluenesulfonylhydrazide ( $0.443 \mathrm{~g}, 2.38 \mathrm{mmol}, 1.00$ equiv. $)$ in one portion. A condenser was then attached and the contents were heated to reflux for $12 \mathrm{~h}$. After this time, the solvent was removed under reduced pressure until the beginning of the formation of a solid. Then, pentane $(100 \mathrm{~mL})$ was added and the precipitate was collected by filtration and washed with pentane. The solid obtained was used in the next step without purification.

N'-(1-(4-bromophenyl)-2,2,2-trifluoroethylidene)-4-methylbenzenesulfonohydrazide (25) was dissolved in a $0.4 \mathrm{M}$ solution of potassium hydroxide $(281 \mathrm{mg}, 5.00 \mathrm{mmol}, 2.00$ equiv.) in $\mathrm{MeOH}(12.5 \mathrm{~mL})$. A condenser was attached and the reaction mixture was stirred at reflux for $0.5 \mathrm{~h}$. Then, the reaction was cooled to room temperature and diluted with water $(15 \mathrm{~mL})$. The crude product was extracted with pentane $(3 \times 20 \mathrm{~mL})$, dried over $\mathrm{MgSO} 4$, filtered and concentrated under reduced pressure. The crude oil was purified by silica gel chromatography using pentane as eluent to afford 1-bromo-4-(1-diazo-2,2,2-trifluoroethyl)benzene (26) as a orange oil (146 mg, $0.551 \mathrm{mmol}, 22 \%)$. The compound was kept as a $0.6 \mathrm{M}$ solution in DCM at $-18{ }^{\circ} \mathrm{C} .{ }^{1} \mathrm{H}$ NMR $\left(400 \mathrm{MHz}, \mathrm{CDCl}_{3}\right) \delta 7.56-7.48(\mathrm{~m}, 2 \mathrm{H}, \mathrm{ArH}), 7.01-6.91(\mathrm{~m}, 2 \mathrm{H}, \mathrm{ArH})$; ${ }^{13} \mathrm{C}$ NMR $\left(101 \mathrm{MHz}, \mathrm{CDCl}_{3}\right) \delta 132.8,125.7(\mathrm{q}, J=270.3 \mathrm{~Hz}), 124.0,123.0,119.7$ (one carbon is not resolved); ${ }^{19} \mathrm{~F} \mathrm{NMR}\left(376 \mathrm{MHz}, \mathrm{CDCl}_{3}\right) \delta-57.5$. Spectral data of the obtained compound is corresponding to the reported values. ${ }^{8}$

\section{4-(1-Diazo-2,2,2-trifluoroethyl)-1,1'-biphenyl (30)}

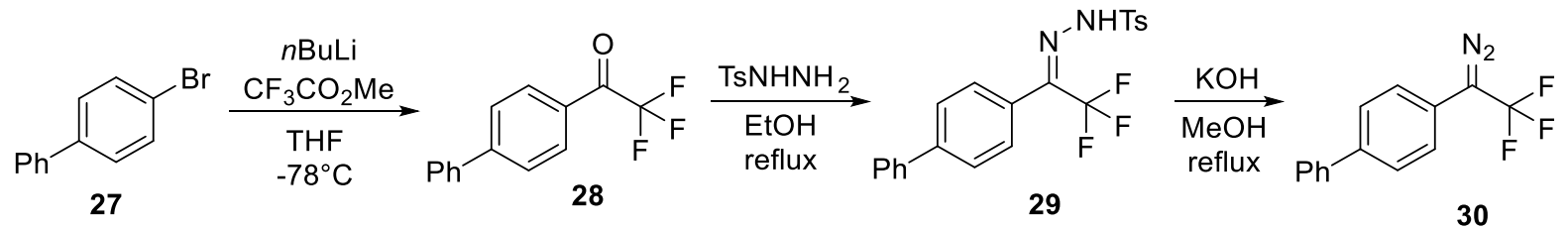

\footnotetext{
${ }^{8}$ G. Pisella, A. Gagnebin, J. Waser, Chem. Eur. J. 2020, 26, 10199.
} 
Following a reported procedure, ${ }^{8}$ a solution of 4-bromo-biphenyl (27) (4.66 g, $20.0 \mathrm{mmol}, 1.00$ equiv.) in anhydrous THF (100 mL) was cooled to $-78{ }^{\circ} \mathrm{C}$. Then, a $2.5 \mathrm{M}$ solution of $\mathrm{n}-$ butyllithium $(9.60 \mathrm{~mL}, 24.0 \mathrm{mmol}, 1.20$ equiv.) in hexanes was added dropwise. The mixture was stirred for $1 \mathrm{~h}$, followed by the dropwise addition of methyl 2,2,2-trifluoroacetate (2.21 $\mathrm{mL}, 22.0 \mathrm{mmol}, 1.10$ equiv.) in $30 \mathrm{~min}$. The mixture was allowed to warm up to room temperature, stirred for $18 \mathrm{~h}$ and then quenched with saturated aqueous ammonium chloride solution $(50 \mathrm{~mL})$. Diethyl ether $(50 \mathrm{~mL})$ was added and the layers were separated. The aqueous layer was extracted with diethyl ether $(2 \times 25 \mathrm{~mL})$. The combined organic layers were washed with brine $(50 \mathrm{~mL})$, dried over $\mathrm{MgSO} 4$, filtrated and concentrated under reduced pressure. The residue was purified by silica gel chromatography using pentane/EtOAc 90:10 as eluent to afford 1-([1,1'-biphenyl]- 4-yl)-2,2,2-trifluoroethanone (28) as a light-yellow oil (3.37 g, 13.5 mmol, 67\%). ${ }^{1} \mathrm{H}$ NMR (400 MHz, $\left.\mathrm{CDCl}_{3}\right) \delta 8.20-8.10(\mathrm{~m}, 2 \mathrm{H}, \mathrm{ArH}), 7.81-7.74(\mathrm{~m}, 2 \mathrm{H}$, $\mathrm{ArH}), 7.68-7.62(\mathrm{~m}, 2 \mathrm{H}, \mathrm{ArH}), 7.54-7.41(\mathrm{~m}, 3 \mathrm{H}, \mathrm{Ar} H) ;{ }^{13} \mathrm{C} \mathrm{NMR}\left(101 \mathrm{MHz}, \mathrm{CDCl}_{3}\right) \delta$ 180.3 (q, $J=34.8 \mathrm{~Hz}), 148.4,139.3,130.9$ (q, $J=2.2 \mathrm{~Hz}), 129.3,129.1,128.7,127.8,127.5$, $116.9(\mathrm{q}, J=291.4 \mathrm{~Hz}) ;{ }^{19} \mathrm{~F} \mathrm{NMR}\left(376 \mathrm{MHz}, \mathrm{CDCl}_{3}\right) \delta-71.32$. Spectral data of the obtained compound is corresponding to the reported values. ${ }^{8}$

Following a reported procedure, 1-([1,1'-biphenyl]-4-yl)-2,2,2-trifluoroethanone (28) (3.36 g, $13.5 \mathrm{mmol}, 1.05$ equiv.) was added to $\mathrm{EtOH}(9 \mathrm{~mL})$ at room temperature followed by $p$ toluenesulfonylhydrazide $(2.40 \mathrm{~g}, 12.9 \mathrm{mmol}, 1.00$ equiv.) in one portion. A condenser was then attached and the contents were heated to reflux for $12 \mathrm{~h}$. After this time, the solvent was removed under reduced pressure until the beginning of the formation of a solid. Then, pentane $(200 \mathrm{~mL})$ was added and the precipitate was collected by filtration and washed with pentane. The solid obtained was used in the next step without purification.

Following a reported procedure, N'-(1-([1,1'-biphenyl]-4-yl)-2,2,2-trifluoroethylidene)-4methylbenzenesulfonohydrazide (29) was dissolved in a $0.4 \mathrm{M}$ solution of potassium hydroxide (3.37 g, $60.0 \mathrm{mmol}, 2.00$ equiv.) in $\mathrm{MeOH}(17.5 \mathrm{~mL})$. A condenser was attached and the reaction mixture was stirred at reflux for $0.5 \mathrm{~h}$. Then, the reaction was cooled to room temperature and diluted with water $(20 \mathrm{~mL})$. The product was extracted with $\mathrm{Et}_{2} \mathrm{O}(3 \times 30 \mathrm{~mL})$, dried over $\mathrm{MgSO}$, filtered and concentrated under reduced pressure. The crude oil was purified by silica gel chromatography using pentane as eluent to afford 4-(1-Diazo-2,2,2trifluoroethyl)-1,1'-biphenyl (30) as a red solid (1.42 g, $5.44 \mathrm{mmol}, 50 \%)$. The compound was kept at $-18{ }^{\circ} \mathrm{C}$. $\mathrm{Rf}=0.70$ (pentane); ${ }^{1} \mathrm{H}$ NMR $\left(400 \mathrm{MHz}, \mathrm{CDCl}_{3}\right) \delta 7.68-7.62(\mathrm{~m}, 2 \mathrm{H}, \mathrm{ArH})$, $7.62-7.55(\mathrm{~m}, 2 \mathrm{H}, \mathrm{ArH}), 7.45(\mathrm{dd}, J=8.4,6.9 \mathrm{~Hz}, 2 \mathrm{H}, \operatorname{Ar} H), 7.41-7.34(\mathrm{~m}, 1 \mathrm{H}, \mathrm{ArH}), 7.17$ $(\mathrm{d}, \mathrm{J}=8.2 \mathrm{~Hz}, 2 \mathrm{H}, \mathrm{ArH}) ;{ }^{13} \mathrm{C} \mathrm{NMR}\left(101 \mathrm{MHz}, \mathrm{CDCl}_{3}\right) \delta 140.2,139.0,129.1,128.2,127.7$, 127.0, 125.8 (q, $J=269.6 \mathrm{~Hz}), 122.7,122.4 ;{ }^{19} \mathrm{~F}$ NMR $\left(376 \mathrm{MHz}, \mathrm{CDCl}_{3}\right) \delta$-57.32. Spectral data of the obtained compound is corresponding to the reported values. ${ }^{8}$

\section{General procedure for Rh-catalysed cyclopropenation of terminal alkynes (GP2)}
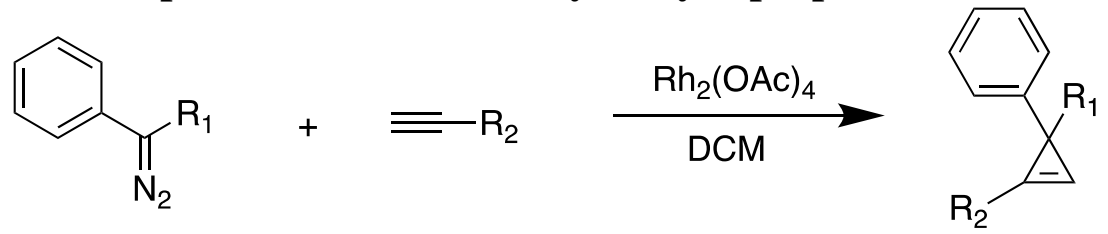

Following a modified reported procedure ${ }^{4}$, the diazo compound was dissolved in DCM $(0.25$ $\mathrm{M})$ and the resulting solution was added via syringe pump to a suspension of $\mathrm{Rh}_{2}(\mathrm{OAc})_{4}(0.01$ equiv.) in indicated alkyne(3.0 equiv.) at room temperature over 10 hours. After the addition was complete, the reaction mixture was allowed to stir for another 4 hours. The reaction mixture was then filtered through a small pad of silica eluting with $\mathrm{CH}_{2} \mathrm{Cl}_{2}$ and the filtrate was 
concentrated under reduced pressure. The crude residue was purified by column chromatography with the indicated solvents.

\section{Methyl 1,2-diphenylcycloprop-2-ene-1-carboxylate (4a)}<smiles>COC(=O)C1(c2ccccc2)C=C1c1ccccc1</smiles>

Following the GP2, starting from methyl 2-diazo-2-phenylacetate (15) (1.40 g, $7.95 \mathrm{mmol}$, 1.00 equiv) and phenylacetylene ( $2.43 \mathrm{~g}, 23.8 \mathrm{mmol}, 3.00$ equiv), the title compound $4 \mathbf{a}$ was obtained after purification by column chromatography $\left(\mathrm{SiO}_{2}\right.$, Pentane:EtOAc 95:5 to 80:20) as a pale yellow oil (1.37 g, $5.47 \mathrm{mmol}, 69 \%$ yield).

$\mathrm{Rf}=0.21$ (EtOAc:Pentane 1:9). ${ }^{1} \mathrm{H}$ NMR $\left(400 \mathrm{MHz}, \mathrm{CDCl}_{3}\right) \delta 7.65-7.60(\mathrm{~m}, 2 \mathrm{H}, \mathrm{ArH}), 7.45$ - 7.37 (m, 5H, ArH), 7.33 - 7.26 (m, 2H, ArH), 7.23 - 7.18 (m, 2H, ArH \& C=CH), 3.72 (s, $3 \mathrm{H}, \mathrm{CO}_{2} \mathrm{CH}_{3}$ ). Spectral data of the obtained compound is corresponding to the reported values ${ }^{4}$.

\section{Benzyl 1,2-diphenylcycloprop-2-ene-1-carboxylate (4b)}<smiles>O=C(OCc1ccccc1)C1(c2ccccc2)C=C1c1ccccc1</smiles>

Following the GP2, starting from benzyl 2-diazo-2-phenylacetate (16) (4.70 g, $18.6 \mathrm{mmol}, 1.00$ equiv) and phenylacetylene (5.71 g, $55.9 \mathrm{mmol}, 3.00$ equiv), the title compound $\mathbf{4 b}$ was obtained after purification by column chromatography ( $\mathrm{SiO}_{2}$, Pentane:EtOAc 90:10) as a white solid (3.37 g, $10.3 \mathrm{mmol}, 55 \%$ yield).

$\mathrm{Rf}=0.25$ (EtOAc:Pentane 1:9). ${ }^{1} \mathrm{H}$ NMR $\left(400 \mathrm{MHz}, \mathrm{CDCl}_{3}\right) \delta 7.62-7.56(\mathrm{~m}, 2 \mathrm{H}, \mathrm{ArH}), 7.44$ $-7.36(\mathrm{~m}, 5 \mathrm{H}, \mathrm{ArH}), 7.32-7.20(\mathrm{~m}, 7 \mathrm{H}, \mathrm{ArH}), 7.21(\mathrm{~s}, 1 \mathrm{H}, \mathrm{C}=\mathrm{CH}), 7.21-7.16(\mathrm{~m}, 1 \mathrm{H}, \mathrm{Ar} H)$, $5.18\left(\mathrm{~s}, 2 \mathrm{H}, \mathrm{CH}_{2}\right)$. Spectral data of the obtained compound is corresponding to the reported values?.

\section{Tert-butyl 1,2-diphenylcycloprop-2-ene-1-carboxylate (4c)}<smiles>CC(C)(C)OC(=O)C1(c2ccccc2)CC1c1ccccc1</smiles>

Following the GP2, starting from tert-butyl 2-diazo-2-phenylacetate (17) $(530 \mathrm{mg}, 2.43 \mathrm{mmol}$, 1.00 equiv) and phenylacetylene ( $2.43 \mathrm{~g}, 23.8 \mathrm{mmol}, 3.00$ equiv), the title compound $4 \mathbf{c}$ was obtained after purification by column chromatography ( $\mathrm{SiO}_{2}$, Pentane:EtOAc 93:7 to 70:30) as an off-white solid ( $247 \mathrm{mg}, 0.845 \mathrm{mmol}, 35 \%$ yield).

\footnotetext{
${ }^{9}$ Hommelsheim, R.; Guo, Y.; Yang, Z.; Empel, C.; Koenigs, R. M., Angew. Chem. Int. Ed. 2019, 58 (4), $1203-$ 1207.
} 
$\mathrm{Rf}=0.36$ (Pentane:EtOAc 80:20); ${ }^{1} \mathrm{H}$ NMR (400 MHz, $\left.\mathrm{CDCl}_{3}\right) \delta 7.66-7.59(\mathrm{~m}, 2 \mathrm{H}, \mathrm{ArH})$, $7.45-7.36$ (m, 5H, ArH), $7.29-7.25$ (m, 2H, ArH), $7.21-7.17$ (m, 2H, ArH \& C=CH), 1.44 $\left(\mathrm{s}, 9 \mathrm{H}, \mathrm{CH}_{3}\right)$. Spectral data of the obtained compound is corresponding to the reported values ${ }^{4}$.

\section{(1-(Trifluoromethyl)cycloprop-2-ene-1,2-diyl)dibenzene (4h)}

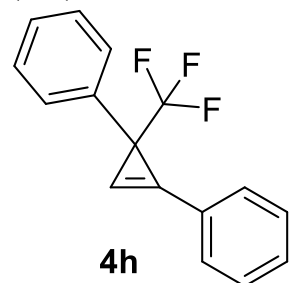

Following the GP2, starting from (1-diazo-2,2,2-trifluoroethyl)benzene (20) (1.86 g, 10.0 mmol, 1.00 equiv.) and phenylacetylene ( $3.64 \mathrm{~g}, 30.0 \mathrm{mmol}, 3.00$ equiv), the title compound 4h was obtained after purification by column chromatography $\left(\mathrm{SiO}_{2}\right.$, Pentane) as a colorless oil (1.98 g, $6.82 \mathrm{mmol}, 68 \%$ yield).

$\mathrm{Rf}=0.39$ (Pentane). ${ }^{1} \mathrm{H}$ NMR $\left(400 \mathrm{MHz}, \mathrm{CDCl}_{3}\right) \delta 7.69-7.63(\mathrm{~m}, 2 \mathrm{H}, \mathrm{ArH}), 7.50-7.39(\mathrm{~m}$, $5 \mathrm{H}, \operatorname{Ar} H), 7.35-7.29(\mathrm{~m}, 2 \mathrm{H}, \operatorname{Ar} H), 7.29-7.24(\mathrm{~m}, 1 \mathrm{H}, \mathrm{ArH}), 7.17(\mathrm{q}, J=1.6 \mathrm{~Hz}, 1 \mathrm{H}, \mathrm{C}=\mathrm{CH})$. Spectral data of the obtained compound is corresponding to the reported values ${ }^{4}$.

\section{1-Methoxy-4-(3-phenyl-3-(trifluoromethyl)cycloprop-1-en-1-yl)benzene (4i)}

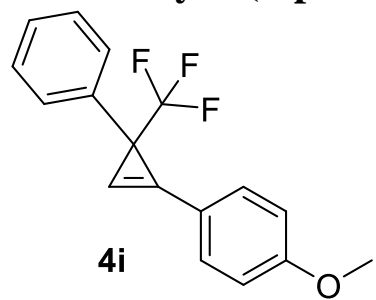

Following the GP2, starting from (1-diazo-2,2,2-trifluoroethyl)benzene (20) (372 mg, 2.00 mmol, 1.00 equiv) and 1-ethynyl-4-methoxybenzene ( $793 \mathrm{mg}, 6.00 \mathrm{mmol}, 3.00$ equiv) the title compound $4 \mathbf{i}$ was obtained after purification by column chromatography $\left(\mathrm{SiO}_{2}, \mathrm{Et}_{2} \mathrm{O}\right.$ :Pentane 2:98) as a yellow oil (423 $\mathrm{mg}, 1.46 \mathrm{mmol}, 73 \%$ yield).

$\mathrm{Rf}=0.53\left(\mathrm{Et}_{2} \mathrm{O}:\right.$ Pentane 1:19). ${ }^{1} \mathrm{H}$ NMR $\left(400 \mathrm{MHz}, \mathrm{CDCl}_{3}\right) \delta 7.58(\mathrm{~d}, J=8.8 \mathrm{~Hz}, 2 \mathrm{H}, \mathrm{Ar} H)$, $7.42(\mathrm{~d}, J=7.8 \mathrm{~Hz}, 2 \mathrm{H}, \mathrm{ArH}), 7.33-7.20(\mathrm{~m}, 3 \mathrm{H}, \mathrm{ArH}), 6.97(\mathrm{~s}, 1 \mathrm{H}, \mathrm{C}=\mathrm{CH}), 6.94(\mathrm{~d}, J=8.8$ $\mathrm{Hz}, 2 \mathrm{H}, \mathrm{ArH}), 3.81\left(\mathrm{~s}, 3 \mathrm{H}, \mathrm{CH}_{3}\right)$. Spectral data of the obtained compound is corresponding to the reported values ${ }^{10}$.

\section{Methyl 4-(3-phenyl-3-(trifluoromethyl)cycloprop-1-en-1-yl)benzoate (4j)}<smiles>COC(=O)c1ccc(C2CC2(c2ccccc2)C(F)(F)F)cc1</smiles>

Following the GP2, starting from (1-diazo-2,2,2-trifluoroethyl)benzene (20) (372 mg, 2.00 mmol, 1.00 equiv) and methyl 4-ethynylbenzoate ( $961 \mathrm{mg}, 6.00 \mathrm{mmol}, 3.00$ equiv) the title compound $\mathbf{4 j}$ was obtained after purification by column chromatography $\left(\mathrm{SiO}_{2}, \mathrm{Et}_{2} \mathrm{O}\right.$ :Pentane 1:99 to 10:90) as a light-yellow oil (425 $\mathrm{mg}, 1.46 \mathrm{mmol}, 73 \%$ yield).

\footnotetext{
${ }^{10}$ Uehara, M.; Suematsu, H.; Yasutomi, Y.; Katsuki, T., J. Am. Chem. Soc. 2011, 133 (2), 170-171.
} 
$\mathrm{Rf}=0.76$ (EtOAc:Pentane 10:90) ${ }^{1} \mathrm{H}$ NMR $\left(400 \mathrm{MHz}, \mathrm{CDCl}_{3}\right) \delta 8.15-8.07(\mathrm{~m}, 2 \mathrm{H}, \mathrm{ArH}), 7.75$ - 7.67 (m, 2H, ArH), $7.44-7.37$ (m, 2H, ArH), 7.35 - 7.26 (m, 4H, ArH \& C=CH), 3.94 (s, $\left.3 \mathrm{H}, \mathrm{CH}_{3}\right) .{ }^{13} \mathrm{C}$ NMR $\left(101 \mathrm{MHz}, \mathrm{CDCl}_{3}\right) \delta 166.3,137.6,131.6,130.2,129.8,129.2,128.5$, 127.6, 127.5, 125.1 (q, $J=277.5 \mathrm{~Hz}), 117.0,102.1,52.4,32.5(\mathrm{q}, J=35.5 \mathrm{~Hz}) .{ }^{19} \mathrm{~F}$ NMR $(376$ $\mathrm{MHz}^{\mathrm{CDCl}} 3$ ) $\delta$-64.1. IR ( $\left.\mathrm{v}_{\max }, \mathrm{cm}^{-1}\right) 3139(\mathrm{w}), 2956(\mathrm{w}), 1722(\mathrm{~s}), 1605(\mathrm{w}), 1496(\mathrm{w}), 1441$ (m), 1410 (w), 1278 (s), 1163 (s), 1114 (s), 1024 (w), 971 (w), 921 (m), 861 (w), 833 (w), 774 (m), 723 (s), 708 (s), 658 (w). HRMS (APCI/QTOF) m/z: $[\mathrm{M}+\mathrm{H}]^{+}$Calcd for $\mathrm{C}_{18} \mathrm{H}_{14} \mathrm{~F}_{3} \mathrm{O}_{2}{ }^{+}$319.0940; Found 319.0955.

\section{1-Fluoro-3-(3-phenyl-3-(trifluoromethyl)cycloprop-1-en-1-yl)benzene (4k)}<smiles>Fc1cccc(C2CC2(c2ccccc2)C(F)(F)F)c1</smiles>

Following the GP2, starting from (1-diazo-2,2,2-trifluoroethyl)benzene (20) (372 mg, 2.00 mmol, 1.00 equiv) and 1-ethynyl-3-fluorobenzene $(721 \mathrm{mg}, 6.00 \mathrm{mmol}, 3.00$ equiv) the title compound $\mathbf{4 k}$ was obtained after purification by column chromatography ( $\mathrm{SiO}_{2}$, Pentane) as a colorless oil (453 mg, $1.63 \mathrm{mmol}, 81 \%$ yield).

$\mathrm{Rf}=0.34$ (pentane). ${ }^{1} \mathrm{H}$ NMR $\left(400 \mathrm{MHz}, \mathrm{CDCl}_{3}\right) \delta 7.38-7.30(\mathrm{~m}, 4 \mathrm{H}, \mathrm{Ar} H), 7.28-7.13(\mathrm{~m}, 5 \mathrm{H}$, $\mathrm{Ar} H \& \mathrm{C}=\mathrm{C} H), 7.11-6.98(\mathrm{~m}, 1 \mathrm{H}, \mathrm{Ar} H) .{ }^{13} \mathrm{C} \mathrm{NMR}\left(101 \mathrm{MHz}, \mathrm{CDCl}_{3}\right) \delta 162.9(\mathrm{~d}, J=247.9$ $\mathrm{Hz}), 137.7,130.7(\mathrm{~d}, J=8.2 \mathrm{~Hz}), 128.5,127.6,127.4,127.1(\mathrm{~d}, J=8.2 \mathrm{~Hz}), 125.8(\mathrm{~d}, J=3.1$ $\mathrm{Hz}), 125.1(\mathrm{q}, J=277.6 \mathrm{~Hz}), 117.6(\mathrm{~d}, J=21.4 \mathrm{~Hz}), 116.8,116.6(\mathrm{~d}, J=22.3 \mathrm{~Hz}), 100.6(\mathrm{~d}$, $J=2.9 \mathrm{~Hz}), 32.5(\mathrm{q}, 36 \mathrm{~Hz}) .{ }^{19} \mathrm{~F} \mathrm{NMR}\left(376 \mathrm{MHz}, \mathrm{CDCl}_{3}\right) \delta-64.1,-111.9$. IR $\left(v_{\max }, \mathrm{cm}^{-1}\right) 3144$ (w), 3068 (w), 3034 (w), 1589 (m), 1490 (m), 1441 (m), 1304 (m), 1256 (m), 1160 (s), 1129 (s), 969 (w), 919 (m), 873 (m), 786 (m), 709 (m), 653 (w). HRMS (nanochip-ESI/LTQOrbitrap) m/z: [M] $]^{+}$Calcd for $\mathrm{C}_{16} \mathrm{H}_{10} \mathrm{~F}_{4}{ }^{+}$278.0713; Found 278.0720.

\section{1-Bromo-4-(2-phenyl-1-(trifluoromethyl)cycloprop-2-en-1-yl)benzene (4l) \\ $\mathrm{Br}$<smiles>Cc1ccc(C23C=C2C3c2ccccc2)cc1</smiles>

Following the GP2, starting from 1-bromo-4-(1-diazo-2,2,2-trifluoroethyl)benzene (26) (362 $\mathrm{mg}, 1.36 \mathrm{mmol}, 1.00$ equiv) and phenylacetylene ( $418 \mathrm{mg}, 4.10 \mathrm{mmol}, 3.00$ equiv), the title compound $4 \mathbf{I}$ was obtained after purification by column chromatography $\left(\mathrm{SiO}_{2}\right.$, Pentane:EtOAc 95:5 to 80:20) as a colorless oil, which solidified upon storage at $-20^{\circ} \mathrm{C}(264 \mathrm{mg}, 778 \mu \mathrm{mol}$, $57 \%$ yield).

$\mathrm{Rf}=0.55$ (pentane). ${ }^{1} \mathrm{H}$ NMR $\left(400 \mathrm{MHz}, \mathrm{CDCl}_{3}\right) \delta 7.67-7.61(\mathrm{~m}, 2 \mathrm{H}, \mathrm{ArH}), 7.51-7.40(\mathrm{~m}$, $5 \mathrm{H}, \operatorname{Ar} H), 7.34-7.27(\mathrm{~m}, 2 \mathrm{H}, \operatorname{Ar} H), 7.14(\mathrm{q}, J=1.5 \mathrm{~Hz}, 1 \mathrm{H}, \mathrm{C}=\mathrm{CH}) .{ }^{13} \mathrm{C}$ NMR $(101 \mathrm{MHz}$, $\left.\mathrm{CDCl}_{3}\right) \delta 137.2,131.6,130.7,130.0,129.4,129.1,126.5(\mathrm{q}, J=277.7 \mathrm{~Hz}), 124.7,121.3,117.3$ $(\mathrm{q}, J=2.3 \mathrm{~Hz}), 98.5(\mathrm{q}, J=2.9 \mathrm{~Hz}), 31.8(\mathrm{q}, J=35.8 \mathrm{~Hz}) .{ }^{19} \mathrm{~F} \mathrm{NMR}\left(376 \mathrm{MHz}, \mathrm{CDCl}_{3}\right) \delta-$ 64.0. IR $\left(\mathrm{cm}^{-1}\right)$ : 3132(w), 1769(m), 1484(m), 1294(m), 1233(m), 1164(s), 1113(s), 1067(m), 1004(m), 974(m), 915(m), 823(m), 763(m), 744(m), 727(m), 699(s). HRMS (APPI/LTQOrbitrap) $\mathrm{m} / \mathrm{z}:[\mathrm{M}]^{+}$Calcd for $\mathrm{C}_{16} \mathrm{H}_{10}{ }^{79} \mathrm{BrF}_{3}{ }^{+}$337.9912; Found 337.9915. 
$\mathrm{Ph}$<smiles>Fc1ccc(C2(C(F)(F)F)C=C2c2ccccc2)cc1</smiles>

Following the GP2, starting from 1-(1-diazo-2,2,2-trifluoroethyl)-4-phenylbenzene (30) (150 $\mathrm{mg}, 572 \mu \mathrm{mol}, 1.00$ equiv) and phenylacetylene (175 mg, $1.72 \mathrm{mmol}, 3.00$ equiv) the title compound $\mathbf{4 m}$ was obtained after purification by column chromatography $\left(\mathrm{SiO}_{2}, \mathrm{Pentane}\right)$ as a white solid (160 mg, $476 \mu \mathrm{mol}, 83 \%$ yield).

$\mathrm{Rf}($ pentane $)=0.18$. M.p. $119-121{ }^{\circ} \mathrm{C} .{ }^{1} \mathrm{H}$ NMR $\left(400 \mathrm{MHz}, \mathrm{CDCl}_{3}\right) \delta 7.73-7.63(\mathrm{~m}, 2 \mathrm{H}, \mathrm{ArH})$, $7.62-7.39(\mathrm{~m}, 11 \mathrm{H}, \operatorname{ArH}), 7.39-7.30(\mathrm{~m}, 1 \mathrm{H}, \operatorname{Ar} H), 7.20(\mathrm{q}, J=1.6 \mathrm{~Hz}, 1 \mathrm{H}, \mathrm{C}=\mathrm{CH}) .{ }^{13} \mathrm{C}$ NMR $\left(101 \mathrm{MHz}, \mathrm{CDCl}_{3}\right) \delta 140.7,140.1,137.2,130.5,130.1,129.1,128.80,128.11,127.3$, 127.2, 127.1, 126.7 (q, 278Hz), 125.0, 117.4, 98.8. 32.0 (q, $J=35.4 \mathrm{~Hz}) .{ }^{19} \mathrm{~F}$ NMR $(376 \mathrm{MHz}$, $\left.\mathrm{CDCl}_{3}\right) \delta$-63.9. IR $\left(v_{\max }, \mathrm{cm}^{-1}\right) 3134(\mathrm{w}), 1487(\mathrm{~m}), 1301(\mathrm{~m}), 1243(\mathrm{~m}), 1158(\mathrm{~s}), 1119(\mathrm{~s})$, $922(\mathrm{~m}), 844(\mathrm{~m}), 768(\mathrm{~m}), 708(\mathrm{~s})$. HRMS (APPI/LTQ-Orbitrap) m/z: [M] ${ }^{+}$Calcd for $\mathrm{C}_{22} \mathrm{H}_{15} \mathrm{~F}_{3}{ }^{+}$336.1120; Found 336.1127.

\section{(2-Propyl-1-(trifluoromethyl)cycloprop-2-en-1-yl)benzene (4n)

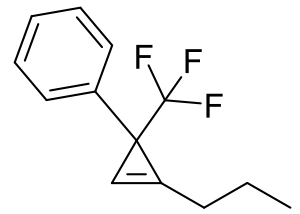 \\ $4 n$}

Following the GP2, starting from (1-diazo-2,2,2-trifluoroethyl)benzene (20) (372 mg, 2.00 mmol, 1.00 equiv) and pent-1-yne ( $409 \mathrm{mg}, 6.00 \mathrm{mmol}, 3.00$ equiv) the title compound $\mathbf{4 n}$ was obtained after purification by column chromatography ( $\mathrm{SiO}_{2}$, Pentane) as a colorless oil (341 $\mathrm{mg}, 1.51 \mathrm{mmol}, 75 \%$ yield).

$\mathrm{Rf}=0.8$ (pentane). ${ }^{1} \mathrm{H}$ NMR $\left(400 \mathrm{MHz}, \mathrm{CDCl}_{3}\right): \delta=7.42-7.34(\mathrm{~m}, 4 \mathrm{H}, \mathrm{ArH}), 7.34-7.26(\mathrm{~m}$, $1 \mathrm{H}, \mathrm{ArH}), 6.79-6.71(\mathrm{~m}, 1 \mathrm{H}, \mathrm{C}=\mathrm{CH}), 2.57\left(\mathrm{tt}, J=7.3,1.6 \mathrm{~Hz}, 2 \mathrm{H}, \mathrm{C}=\mathrm{C}-\mathrm{CH} \mathrm{H}_{2}\right), 1.80-1.60$ $\left(\mathrm{m}, 2 \mathrm{H}, \mathrm{CH}_{2} \mathrm{CH}_{2} \mathrm{CH}_{3}\right), 1.12-0.90(\mathrm{~m}, 3 \mathrm{H}, \mathrm{CH})$. Spectral data of the obtained compound is corresponding to the reported values ${ }^{11}$.

\section{3-(3-(3,5-Dichlorophenyl)-3-(trifluoromethyl)cycloprop-1-en-1-yl)thiophene (4q)}

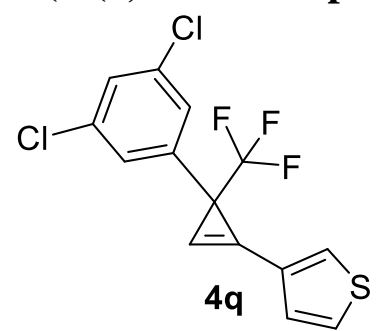

Following the GP2, starting from 1,3-dichloro-5-(1-diazo-2,2,2-trifluoroethyl)benzene (23) (118 mg, $462 \mu \mathrm{mol}, 1.00$ equiv) and 3-ethynylthiophene (150 mg, $1.39 \mathrm{mmol}, 3.00$ equiv) the

\footnotetext{
${ }^{11}$ Tran, U. P.; Hommelsheim, R.; Yang, Z.; Empel, C.; Hock, K. J.; Nguyen, T. V.; Koenigs, R. M., Chem. Eur. J. 2020, 26 (6), 1254-1257.
} 
title compound $\mathbf{4 q}$ was obtained after purification by column chromatography ( $\mathrm{SiO}_{2}$, Pentane) as a yellow oil (75.6 mg, $226 \mu \mathrm{mol}, 49 \%$ yield).

$\mathrm{Rf}=0.52$ (pentane). ${ }^{1} \mathrm{H}$ NMR $\left(400 \mathrm{MHz}, \mathrm{CDCl}_{3}\right) \delta 7.57(\mathrm{dd}, J=3.0,1.2 \mathrm{~Hz}, 1 \mathrm{H}, \mathrm{Ar} H), 7.33$ $(\mathrm{dd}, J=5.1,2.9 \mathrm{~Hz}, 1 \mathrm{H}, \mathrm{Ar} H), 7.24(\mathrm{dd}, J=5.0,1.2 \mathrm{~Hz}, 1 \mathrm{H}, \mathrm{Ar} H), 7.22-7.14(\mathrm{~m}, 3 \mathrm{H}, \operatorname{Ar} H)$, $6.86(\mathrm{q}, J=1.6 \mathrm{~Hz}, 1 \mathrm{H}, \mathrm{C}=\mathrm{CH}) .{ }^{13} \mathrm{C}$ NMR $\left(101 \mathrm{MHz}, \mathrm{CDCl}_{3}\right) \delta 141.6,135.1,129.6,128.0$, 127.6, 127.4, $126.2(\mathrm{q}, J=1.7 \mathrm{~Hz}), 126.1(\mathrm{q}, J=277.6 \mathrm{~Hz}), 125.4,111.5(\mathrm{q}, J=2.3 \mathrm{~Hz}), 94.9$ $(\mathrm{q}, J=2.8 \mathrm{~Hz}), 31.6(\mathrm{q}, J=36.2 \mathrm{~Hz}) .{ }^{19} \mathrm{~F} \mathrm{NMR}\left(376 \mathrm{MHz}, \mathrm{CDCl}_{3}\right) \delta-64.1$. HRMS (APPI/LTQOrbitrap) m/z: [M] ${ }^{+}$Calcd for $\mathrm{C}_{14} \mathrm{H}_{7} \mathrm{Cl}_{2} \mathrm{~F}_{3} \mathrm{~S}^{+}$333.9592; Found 333.9605.

\section{Methyl 1-phenylcycloprop-2-ene-1-carboxylate (4d)}

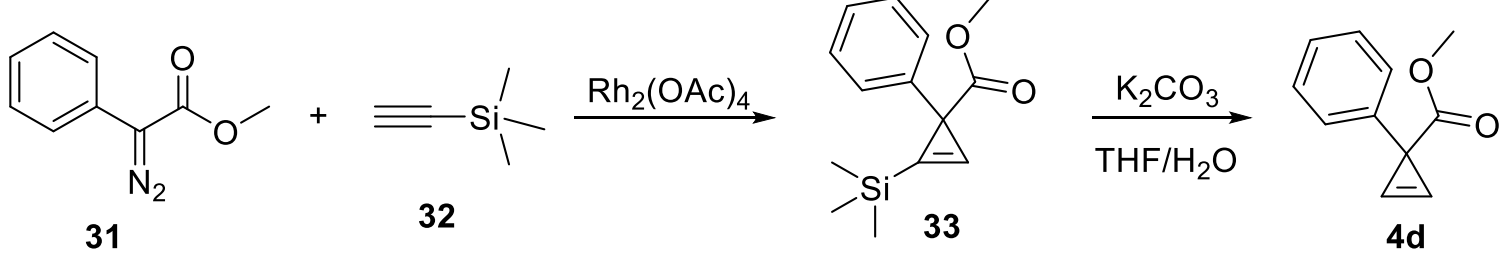

Following a reported procedure ${ }^{12}$, A solution of methyl diazophenylacetate (31) $(2.95 \mathrm{~g}, 16.8$ mmol) in trimethylsilylacetylene (32) $(20 \mathrm{~mL})$ was added via a syringe pump over $18 \mathrm{~h}$ to a stirred suspension of $\mathrm{Rh}_{2}(\mathrm{OAc})_{4}$ (74 $\mathrm{mg}, 0.17 \mathrm{mmol}, 1 \mathrm{~mol} \%$ ) in trimethylsilylacetylene (32) $(15 \mathrm{~mL})$ at $50{ }^{\circ} \mathrm{C}$ under $\mathrm{N}_{2}$ atmosphere. After the addition was complete, the reaction mixture was refluxed for an additional $2 \mathrm{~h}$. The reaction mixture was concentrated under vacuum, diluted with DCM $(20 \mathrm{~mL})$, filtered through a small pad of silica gel $(1 \mathrm{~cm})$. The sorbent was washed with DCM $(50 \mathrm{~mL})$. The mother liquor was concentrated under vacuum to give methyl 1-phenyl-2-(trimethylsilyl)cycloprop-2-ene-1-carboxylate (33) (3.63 g, 90\% purity, 13.3 mmol, 79\% yield), which was used in the next step without further purification.

${ }^{1} \mathrm{H}$ NMR $\left(400 \mathrm{MHz}, \mathrm{CDCl}_{3}\right) \delta 7.42(\mathrm{~s}, 1 \mathrm{H}, \mathrm{C}=\mathrm{CH}), 7.30-7.22(\mathrm{~m}, 4 \mathrm{H}, \mathrm{ArH}), 7.19-7.14(\mathrm{~m}$, $1 \mathrm{H}, \mathrm{ArH}), 3.66\left(\mathrm{~s}, 3 \mathrm{H}, \mathrm{OCH}_{3}\right), 0.18\left(\mathrm{~s}, 9 \mathrm{H}, \mathrm{Si}\left(\mathrm{CH}_{3}\right)_{3}\right)$. The spectral data of the obtained compound is corresponding to the reported values ${ }^{12}$.

To a solution of 33 (3.63 g, $14.7 \mathrm{mmol}$, 1 equiv) in THF $(70 \mathrm{~mL})$, cooled to $0{ }^{\circ} \mathrm{C}$, a solution of $\mathrm{K}_{2} \mathrm{CO}_{3}$ (3.00 g, $21.7 \mathrm{mmol}, 1.5$ equiv) was added dropwise. The reaction mixture was stirred at $\mathrm{r}$.t for $2 \mathrm{~h}$, then extracted with $\mathrm{Et}_{2} \mathrm{O}(2 \times 100 \mathrm{~mL})$. The combined organic layers were washed with brine $(100 \mathrm{~mL})$, dried over $\mathrm{Na}_{2} \mathrm{SO}_{4}$, filtered and concentrated under vacuum to give the crude product, which was purified by column chromatography $\left(\mathrm{SiO}_{2}\right.$, Pentane:EtOAc 90:10) to give methyl 1-phenylcycloprop-2-ene-1-carboxylate (4d) $(1.55 \mathrm{~g}, 8.87 \mathrm{mmol}, 53.2 \%$ yield over 2 steps) as a yellow oil.

$\mathrm{Rf}=0.38$ (Pentane:EtOAc 5:1). ${ }^{1} \mathrm{H}$ NMR $\left(\mathrm{CDCl}_{3}, 400 \mathrm{MHz}\right) \delta$ 7.36-7.25 (m, 5H, ArH), 7.23 $(\mathrm{s}, 2 \mathrm{H}, \mathrm{C}=\mathrm{CH}), 3.72(\mathrm{~m}, 3 \mathrm{H}, \mathrm{CH})$; The spectral data of the obtained compound is corresponding to the reported values ${ }^{12}$.

\section{General procedure for the preparation of cyclopropenes via bromide elimination(GP3)}

\footnotetext{
${ }^{12}$ Rubin, M.; Gevorgyan, V., Synthesis 2004, 2004 (05), 796-800.
} 


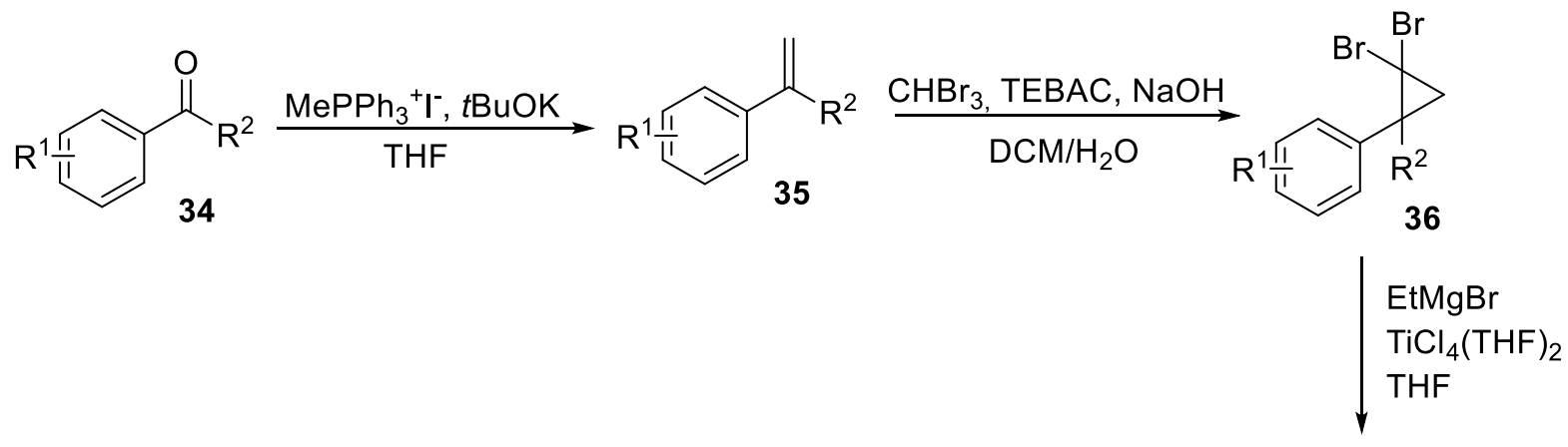

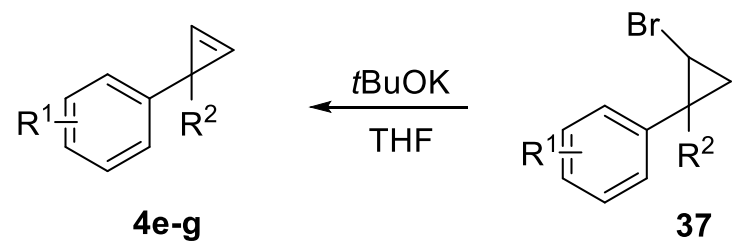

To a solution of methyltriphenylphosphonium iodide (1.36 equiv) in THF ( $0.25 \mathrm{M}) t \mathrm{BuOK}$ (1.3equiv) was added under nitrogen atmosphere. The reaction mixture was stirred for $1 \mathrm{~h}$, then ketone 34 ( 1 equiv) was added. The mixture was stirred overnight. The reaction mixture was diluted with water and extracted with EtOAc $(3 \mathrm{x})$. The combined organic layers were washed with brine, dried over $\mathrm{MgSO}_{4}$, filtered and concentrated under vacuum. The resulting crude was triturated with pentane. The mixture was stirred for $2 \mathrm{~h}$ to assure full dissolving of the alkene 35 product. The mixture was filtered, the precipitate was washed with pentane. The mother liquor was concentrated under vacuum to give crude 35 , which was used without further purification.

To a solution of crude alkene 35 (1equiv), $\mathrm{CHBr}_{3}$ (2.5equiv) and triethylbenzylammonium chloride (0.1 equiv.) in DCM ( $1 \mathrm{M})$ a $50 \% \mathrm{NaOH}$ solution (14.2 equiv) was added dropwise. The reaction mixture was stirred overnight at r.t. The reaction mixture was diluted with water and extracted with DCM (2x). The combined organic layers were dried over $\mathrm{Na}_{2} \mathrm{SO}_{4}$, filtered and concentrated under vacuum to give dibromocyclopropane 36, which was used without further purification.

To a solution of 36 (1equiv) and $\mathrm{TiCl}_{4}(\mathrm{THF})_{2}$ (0.025 equiv) in $\mathrm{THF}(0.25 \mathrm{M}) \mathrm{EtMgBr}$ (1.5equiv, $3.2 \mathrm{M}$ in 2-MeTHF) was added dropwise over 10 min under $\mathrm{N}_{2}$ atmosphere. The reaction mixture was stirred for another $10 \mathrm{~min}$. Water was added. The organic solvent was concentrated under vacuum. The mixture was diluted with water and extracted with pentane $(3 x)$. The combined organic extracts were dried over $\mathrm{Na}_{2} \mathrm{SO}_{4}$, filtered and concentrated under vacuum to give crude bromide 37 which was used without further purification.

To a solution of $t \mathrm{BuOK}$ ( 2 equiv) in THF $(0.5 \mathrm{M})$, cooled to $0{ }^{\circ} \mathrm{C}$, a solution of 37 in THF (1 $\mathrm{M})$ was added under $\mathrm{N}_{2}$ atmosphere. The reaction mixture was stirred at r.t for 20-48 h. The reaction mixture was poured into ice/water, extracted with pentane $(3 \mathrm{x})$. The combined organic extracts were washed with brine, dried over $\mathrm{Na}_{2} \mathrm{SO}_{4}$, filtered and concentrated under vacuum to give crude product. This crude was subjected to column chromatography ( $\mathrm{SiO}_{2}$, pentane) to give cyclopropene $\mathbf{4 e - g}$.

\section{3,3-Diphenylcyclopropene (4e)}

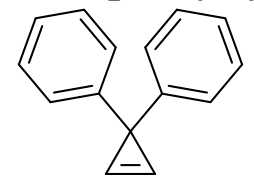

$4 e$ 
Following the GP3, starting from benzophenone $(1.16 \mathrm{~g}, 6.37 \mathrm{mmol})$ the title compound $4 \mathrm{e}$ was obtained as a colorless oil (576 mg, $3.00 \mathrm{mmol}$, $47 \%$ yield over 4 steps).

$\mathrm{Rf}=0.8$ (pentane). ${ }^{1} \mathrm{H}$ NMR $\left(400 \mathrm{MHz}, \mathrm{CDCl}_{3}\right) \delta 7.49(\mathrm{~s}, 2 \mathrm{H}, \mathrm{C}=\mathrm{CH}), 7.32-7.23(\mathrm{~m}, 4 \mathrm{H}$, $\operatorname{Ar} H), 7.23-7.13(\mathrm{~m}, 6 \mathrm{H}, \mathrm{ArH})$. Spectral data of the obtained compound is corresponding to the reported values ${ }^{13}$.

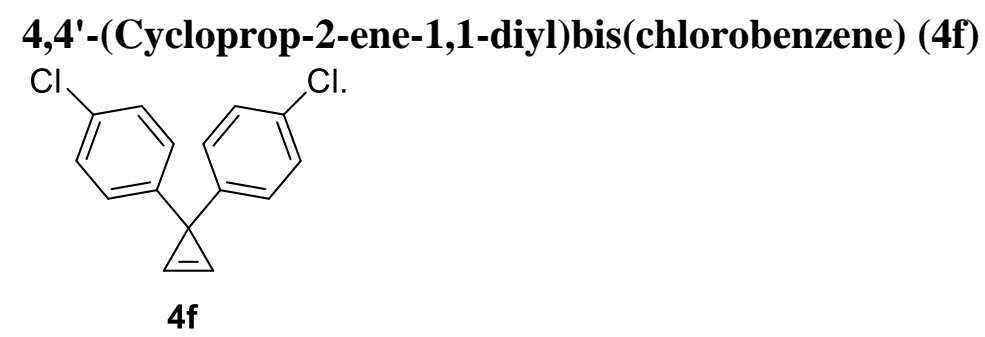

Following the GP3, starting from 4,4'-dichlorobenzophenone $(0.673 \mathrm{~g}, 2.68 \mathrm{mmol})$ the title compound $4 \mathbf{f}$ was obtained as a white solid $(273 \mathrm{mg}, 1.04 \mathrm{mmol}, 38.8 \%$ yield over 4 steps). $\mathrm{Rf}=0.68$ (Pentane). ${ }^{1} \mathrm{H}$ NMR (400 MHz, $\left.\mathrm{CDCl}_{3}\right)$ 7.05-7.08 (m, 4H, ArH), 7.21-7.25 (m, 4H, $\mathrm{ArH}), 7.45(\mathrm{~s}, 2 \mathrm{H}, \mathrm{C}=\mathrm{CH})$. Spectral data of the obtained compound is corresponding to the reported values ${ }^{14}$.

\section{(1-Methylcycloprop-2-en-1-yl)benzene (4g)}

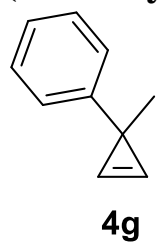

Following the GP3, starting from prop-1-en-2-ylbenzene $(0.600 \mathrm{~g}, 5.00 \mathrm{mmol})$ the title compound $\mathbf{4 g}$ was obtained as a light-yellow oil (310 $\mathrm{mg}, 2.38 \mathrm{mmol}, 48 \%$ yield over 3 steps). $\mathrm{Rf}=0.7$ (pentane). ${ }^{1} \mathrm{H}$ NMR $\left(400 \mathrm{MHz}, \mathrm{CDCl}_{3}\right) \delta 7.63(\mathrm{t}, J=8.0 \mathrm{~Hz}, 2 \mathrm{H}, \mathrm{ArH}), 7.58-7.56$ $(\mathrm{m}, 2 \mathrm{H}, \mathrm{Ar} H), 7.53(\mathrm{~s}, 2 \mathrm{H}, \mathrm{C}=\mathrm{CH}), 7.50(\mathrm{t}, J=7.2 \mathrm{~Hz}, 1 \mathrm{H}, \mathrm{ArH}), 2.01$ (s, 3H, CH3). Spectral data of the obtained compound is corresponding to the reported values ${ }^{15}$.

General procedure for Ag-catalyzed cyclopropenation of internal alkynes (GP4)

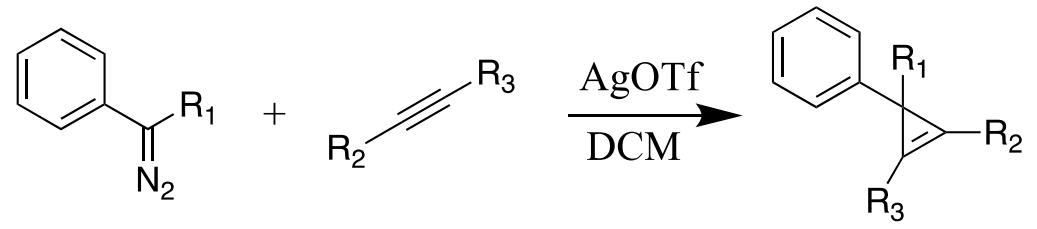

Following a modified reported procedure ${ }^{16}$, a mixture of alkyne (4.0 mmol, 2 equiv.) and AgOTf ( $51 \mathrm{mg}, 0.20 \mathrm{mmol}, 0.10$ equiv) was weighed in a $100-\mathrm{mL}$ one-necked round bottom flask covered with aluminum foil to exclude light. The mixture was dissolved with $20 \mathrm{~mL}$ dichloromethane and stirred at room temperature under positive pressure of $\mathrm{N}_{2}$. The diazo compound ( $2 \mathrm{mmol}, 1$ equiv) in $20 \mathrm{~mL}$ dichloromethane was then added via syringe pump over $1 \mathrm{~h}$. After addition, the mixture was stirred for 1 hour. Then, the mixture was filtered through

\footnotetext{
${ }^{13}$ Nizovtsev, A. V., Org. Prep. Proced. Int. 2020, 52 (6), 537-542.

${ }^{14}$ Shintani, R.; lino, R.; Nozaki, K., J. Am. Chem. Soc. 2014, 136 (22), 7849-7852.

15 Phan, D. H.; Kou, K. G.; Dong, V. M., J. Am. Chem. Soc. 2010, 132 (46), 16354-16355.

${ }^{16}$ Briones, J. F.; Davies, H. M., Org. Lett. 2011, 13 (15), 3984-3987.
} 
a small pad of silica gel $(1 \mathrm{~cm})$, the sorbent was washed with DCM; the mother liquor was concentrated in vacuo. The residue was purified on silica with the indicated solvents.

\section{(3-Ethyl-1-(trifluoromethyl)cycloprop-2-ene-1,2-diyl)dibenzene (4o)}<smiles>CCC1C(c2ccccc2)C1(c1ccccc1)C(F)(F)F</smiles>

Following the GP4, starting from (1-diazo-2,2,2-trifluoroethyl)benzene (20) (372 mg, 2.00 mmol, 1.00 equiv) and but-1-yn-1-ylbenzene $(520 \mathrm{mg}, 4.00 \mathrm{mmol}, 2.00$ equiv) the title compound 40 was obtained after purification by column chromatography ( $\mathrm{SiO}_{2}$, Pentane) as a colorless oil (350 mg, $1.21 \mathrm{mmol}, 61 \%$ yield).

$\operatorname{Rf}($ pentane $)=0.44 .{ }^{1} \mathrm{H}$ NMR $\left(400 \mathrm{MHz}, \mathrm{CDCl}_{3}\right) \delta 7.66-7.57(\mathrm{~m}, 2 \mathrm{H}, \mathrm{ArH}), 7.52-7.35(\mathrm{~m}$, $5 \mathrm{H}, \mathrm{ArH}), 7.36-7.21(\mathrm{~m}, 3 \mathrm{H}, \mathrm{ArH}), 2.89-2.68\left(\mathrm{~m}, 2 \mathrm{H}, \mathrm{CH}_{2}\right), 1.40$ (t, $\left.J=7.5 \mathrm{~Hz}, 3 \mathrm{H}, \mathrm{CH} 3\right)$. ${ }^{13} \mathrm{C}$ NMR $\left(101 \mathrm{MHz}, \mathrm{CDCl}_{3}\right) \delta 138.5,129.5,129.2,128.9,128.4,127.6,127,1(\mathrm{q}, 277 \mathrm{~Hz})$, 126.8, 126.2, 114.6, 107.8, $33.7(\mathrm{q}, J=34.6 \mathrm{~Hz}) .18 .1,12.1 .{ }^{19} \mathrm{~F} \mathrm{NMR}\left(376 \mathrm{MHz}, \mathrm{CDCl}_{3}\right) \delta-$ 62.7. IR ( $\left.v_{\max }, \mathrm{cm}^{-1}\right) 3065(\mathrm{w}), 3033(\mathrm{w}), 2979(\mathrm{w}), 2935(\mathrm{w}), 2887(\mathrm{w}), 1496(\mathrm{~m}), 1454(\mathrm{~m})$, 1300 (m), 1248 (m), 1157 (s), 1124 (s), 1078 (w), 919 (m), 761 (m), 699 (s), 654 (w). HRMS (APPI/LTQ-Orbitrap) m/z: [M] ${ }^{+}$Calcd for $\mathrm{C}_{18} \mathrm{H}_{15} \mathrm{~F}_{3}{ }^{+}$288.1120; Found 288.1126.

\section{(3-(Trifluoromethyl)cycloprop-1-ene-1,2,3-triyl)tribenzene (4p)}<smiles>FC(F)(F)C1(c2ccccc2)C(c2ccccc2)=C1c1ccccc1</smiles>

Following the GP4, starting from (1-diazo-2,2,2-trifluoroethyl)benzene (20) (372 mg, 2.00 mmol, 1.00 equiv) and 1,2-diphenylethyne ( $713 \mathrm{mg}, 4.00 \mathrm{mmol}, 2.00$ equiv) the title compound $4 \mathbf{p}$ was obtained after purification by column chromatography $\left(\mathrm{SiO}_{2}\right.$, Pentane) as a white solid (315 mg, $0.936 \mathrm{mmol}, 47 \%$ yield).

$\mathrm{Rf}=0.34$ (Pentane). ${ }^{1} \mathrm{H}$ NMR $\left(400 \mathrm{MHz}, \mathrm{CDCl}_{3}\right) \delta 7.82-7.75(\mathrm{~m}, 4 \mathrm{H}, \mathrm{Ar} H), 7.57-7.47(\mathrm{~m}$, $6 \mathrm{H}, \mathrm{ArH}), 7.47-7.39$ (m, 2H, $\mathrm{ArH}), 7.34-7.20$ (m, 3H, $\mathrm{ArH}) .{ }^{13} \mathrm{C} \mathrm{NMR}\left(101 \mathrm{MHz}, \mathrm{CDCl}_{3}\right)$ $\delta 137.4,130.0,129.8,129.2,128.5,127.6,127.1,127.0(\mathrm{q}, J=278.8 \mathrm{~Hz}), 126.2,109.9,33.7$ $(\mathrm{q}, J=34.6 \mathrm{~Hz}) .{ }^{19} \mathrm{~F}$ NMR $\left(376 \mathrm{MHz}, \mathrm{CDCl}_{3}\right) \delta-62.0$. IR $\left(v_{\max }, \mathrm{cm}^{-1}\right) 3064(\mathrm{~m}), 3033(\mathrm{w})$, 1957 (w), 1883 (w), $1834(\mathrm{w}), 1750(\mathrm{w}), 1602$ (w), $1495(\mathrm{~m}), 1450(\mathrm{w}), 1299(\mathrm{~m}), 1251(\mathrm{~m})$, 1225 (m), 1159 (s), 1122 (s), 1078 (m), 1029 (w), 957 (w), 919 (m), 835 (w), 756 (s), 693 (s), 659 (w). HRMS (APPI/LTQ-Orbitrap) m/z: [M] ${ }^{+}$Calcd for $\mathrm{C}_{22} \mathrm{H}_{15} \mathrm{~F}_{3}{ }^{+}$336.1120; Found 336.1128. M.p. $110-112^{\circ} \mathrm{C}$

\section{(3-(3,5-Dichlorophenyl)-3-(trifluoromethyl)cycloprop-1-ene-1,2-diyl)dibenzene (4r)}


<smiles>FC(F)(F)C1(c2ccccc2)C(c2ccccc2)=C1c1ccccc1</smiles>

Following the GP4, starting from (1-diazo-2,2,2-trifluoroethyl)benzene (23) (145 mg, 569 $\mu \mathrm{mol}, 1.00$ equiv) and 1,2-diphenylethyne (203 mg, $1.14 \mathrm{mmol}, 2.00$ equiv) the title compound $4 \mathbf{r}$ was obtained after purification by column chromatography $\left(\mathrm{SiO}_{2}\right.$ impregnated with $\mathrm{AgNO}_{3}$ ,${ }^{17}$ Pentane) as a white solid (95.4 mg, $235 \mu \mathrm{mol}, 41 \%$ yield).

$\mathrm{Rf}=0.53$ (Pentane). M.p. $118-120^{\circ} \mathrm{C} .{ }^{1} \mathrm{H}$ NMR $\left(400 \mathrm{MHz}, \mathrm{CDCl}_{3}\right) \delta 7.66-7.58(\mathrm{~m}, 4 \mathrm{H}, \mathrm{Ar} H)$, $7.39(\mathrm{dd}, J=8.2,6.5 \mathrm{~Hz}, 4 \mathrm{H}, \operatorname{Ar} H), 7.35-7.28(\mathrm{~m}, 2 \mathrm{H}, \operatorname{Ar} H), 7.26(\mathrm{~d}, J=1.9 \mathrm{~Hz}, 2 \mathrm{H}, \operatorname{Ar} H)$, $7.12(\mathrm{t}, J=1.9 \mathrm{~Hz}, 1 \mathrm{H}, \mathrm{ArH}) .{ }^{13} \mathrm{C} \mathrm{NMR}\left(101 \mathrm{MHz}, \mathrm{CDCl}_{3}\right) \delta 141.1,135.2,130.3,130.1,129.4$, $127.4,126.5(\mathrm{q}, J=276 \mathrm{~Hz}), 125.9(\mathrm{q}, J=1.9 \mathrm{~Hz}), 125.3,108.8(\mathrm{~d}, J=2.5 \mathrm{~Hz}), 33.4(\mathrm{q}, J=$ $35.4 \mathrm{~Hz}) .{ }^{19} \mathrm{~F} \mathrm{NMR}\left(376 \mathrm{MHz}, \mathrm{CDCl}_{3}\right) \delta$-61.7. HRMS (APPI/LTQ-Orbitrap) m/z: $[\mathrm{M}]^{+} \mathrm{Calcd}$ for $\mathrm{C}_{22} \mathrm{H}_{13} \mathrm{Cl}_{2} \mathrm{~F}_{3}{ }^{+}$404.0341; Found 404.0353.

\section{Synthesis of quinolines}

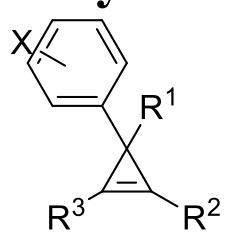

$0.2 \mathrm{mmol}$

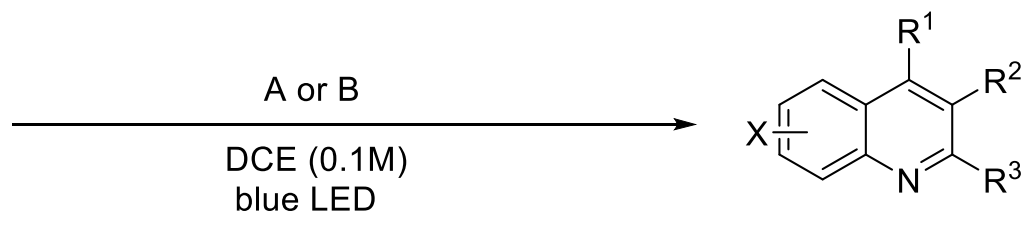

A: $A B Z$ (1.4 equiv.), BIOAc (0.2 equiv.), Pyridine (2 equiv.), $14 \mathrm{~h}$

$B$ : $A B Z$ (2 equiv.), BIOAc ( 0.2 equiv.), Pyridine ( 2 equiv.), $48 \mathrm{~h}$

\section{General procedure for quinoline synthesis: Method A (GP5)}

DCE was degassed by bubbling Ar through it for $30 \mathrm{~min}$. A $5 \mathrm{~mL}$ test tube, equipped with a stirring bar was charged with ABZ (6) $(124 \mathrm{mg}, 0.280 \mathrm{mmol}, 1.40$ equiv) and (3-oxo1lambda3,2-benziodoxol-1-yl)acetate $(7)^{18}(12.2 \mathrm{mg}, 0.0400 \mathrm{mmol}, 0.200$ equiv) and cyclopropene (4) $(0.2 \mathrm{mmol}, 1$ equiv) (if it is solid). It was capped with the septum and evacuated-refilled with $\mathrm{N}_{2}(3 \mathrm{x})$. A solution of cyclopropene (4) $(0.2 \mathrm{mmol}, 1$ equiv) (if oil) in DCE $(2 \mathrm{~mL})$ was added / $2 \mathrm{~mL}$ of DCE was added to the reaction mixture, followed by pyridine (31.6 mg, $400 \mu \mathrm{mol}, 2.00$ equiv). The reaction mixture was stirred under blue LED irradiation for $14 \mathrm{~h}$. Then, the reaction mixture was filtered through a small pad of silica $(1 \mathrm{~cm})$, washing the sorbent with EtOAc. The resulting solution was concentrated under vacuum to give the crude product, which was purified by flash chromatography using the indicated solvents to give the quinoline product.

\section{General procedure for quinoline synthesis: Method B (GP6)}

\footnotetext{
${ }^{17}$ The sorbent was modified by mixing a solution of $5.5 \mathrm{~g}$ of $\mathrm{AgNO}_{3}$ in $\mathrm{MeCN}$ with $50 \mathrm{~g}$ of silica gel, followed by evaporation and drying under vacuum.
}

18 P. Caramenti, S. Nicolai, J. Waser, Chem. Eur. J., 2017, 23, 14702 
A procedure analogous to the method A was used, however 2 equiv of ABZ were used (177 $\mathrm{mg}, 0.400 \mathrm{mmol}$ ); the reaction time was extended to $48 \mathrm{~h}$.

\section{Methyl 3-phenylquinoline-4-carboxylate (5a)}<smiles>CC(=O)c1c(-c2ccccc2)cnc2ccccc12</smiles>

Following the GP5, starting from methyl 1,2-diphenylcycloprop-2-ene-1-carboxylate (4a) (50.1 mg, $200 \mu \mathrm{mol}, 1.00$ equiv) the title compound 5a was obtained after purification by column chromatography ( $\mathrm{SiO}_{2}$, EtOAc:Pentane 10:90) as a yellow oil $(20.0 \mathrm{mg}, 76.0 \mu \mathrm{mol}$, $38 \%$ yield).

$\mathrm{Rf}=0.42\left(\right.$ Pentane:EtOAc 90:10. ${ }^{1} \mathrm{H}$ NMR $\left(400 \mathrm{MHz}, \mathrm{CDCl}_{3}\right) \delta 9.02(\mathrm{~s}, 1 \mathrm{H}, \mathrm{ArH}), 8.19(\mathrm{~d}, J=$ $8.3 \mathrm{~Hz}, 1 \mathrm{H}, \operatorname{Ar} H), 7.92(\mathrm{~d}, J=8.5 \mathrm{~Hz}, 1 \mathrm{H}, \operatorname{ArH}), 7.78$ (ddd, $J=8.4,6.9,1.4 \mathrm{~Hz}, 1 \mathrm{H}, \operatorname{Ar} H)$, 7.65 (ddd, $J=8.2,6.8,1.3 \mathrm{~Hz}, 1 \mathrm{H}, \mathrm{ArH}), 7.53-7.45$ (m, 5H, ArH), 3.78 (s, 3H, CH3); Spectral data of the obtained compound is corresponding to the reported values. ${ }^{4}$

\section{Benzyl 3-phenylquinoline-4-carboxylate (5b)}<smiles>O=C(c1ccccc1)c1c(-c2ccccc2)cnc2ccccc12</smiles>

$5 b$

Following the GP5, starting from benzyl 1,2-diphenylcycloprop-2-ene-1-carboxylate (4b) (65.3 $\mathrm{mg}, 200 \mu \mathrm{mol}, 1.00$ equiv) the title compound $\mathbf{5 b}$ was obtained after purification by column chromatography $\left(\mathrm{SiO}_{2}\right.$, EtOAc:Pentane 10:90) as a yellow oil $(29.0 \mathrm{mg}, 85.4 \mu \mathrm{mol}$, $43 \%$ yield).

$\mathrm{Rf}=0.24$ (EtOAc:pentane 1:9). ${ }^{1} \mathrm{H}$ NMR $\left(400 \mathrm{MHz}, \mathrm{CDCl}_{3}\right) \delta 8.92(\mathrm{~s}, 1 \mathrm{H}, \mathrm{ArH}), 8.10$ (dt, $J=$ 8.5, $0.9 \mathrm{~Hz}, 1 \mathrm{H}, \mathrm{ArH}), 7.84$ (dd, $J=8.2,1.4 \mathrm{~Hz}, 1 \mathrm{H}, \mathrm{ArH}), 7.68$ (ddd, $J=8.4,6.9,1.4 \mathrm{~Hz}, 1 \mathrm{H}$, $\operatorname{ArH}), 7.54$ (ddd, $J=8.3,6.9,1.3 \mathrm{~Hz}, 1 \mathrm{H}, \operatorname{ArH}), 7.43-7.30(\mathrm{~m}, 5 \mathrm{H}, \operatorname{ArH}), 7.25-7.11(\mathrm{~m}, 3 \mathrm{H}$, $\mathrm{ArH}), 7.00-6.90(\mathrm{~m}, 2 \mathrm{H}, \mathrm{ArH}), 5.14\left(\mathrm{~s}, 2 \mathrm{H}, \mathrm{CH}_{2}\right) .{ }^{13} \mathrm{C} \mathrm{NMR}\left(101 \mathrm{MHz}, \mathrm{CDCl}_{3}\right) \delta 167.3$, 151.4, 147.2, 137.1, 136.8, 134.5, 131.8, 129.8, 128.9, 128.8, 128.6, 128.6, 128.5, 128.4, 128.1, 125.0, 123.8, 67.8.(one carbon is not resolved). IR ( $\left.v_{\max }, \mathrm{cm}^{-1}\right) 3061(\mathrm{~m}), 3035(\mathrm{~m}), 2953(\mathrm{~m})$, 2108 (m), 1959 (m), $1886(\mathrm{~m}), 1814(\mathrm{~m}), 1729(\mathrm{~s}), 1576(\mathrm{~m}), 1497(\mathrm{~m}), 1454(\mathrm{~m}), 1377(\mathrm{~m})$, $1321(\mathrm{~m}), 1254$ (s), $1212(\mathrm{~s}), 1140(\mathrm{~m}), 1088(\mathrm{~m}), 1023(\mathrm{~m}), 946(\mathrm{~m}), 912(\mathrm{~m}), 759(\mathrm{~s}), 701(\mathrm{~s})$, $644(\mathrm{~m}), 607$ (m). HRMS (ESI/QTOF) m/z: $[\mathrm{M}+\mathrm{H}]^{+}$Calcd for $\mathrm{C}_{23} \mathrm{H}_{18} \mathrm{NO}_{2}{ }^{+}$340.1332; Found 340.1330 .

\section{Tert-butyl 3-phenylquinoline-4-carboxylate (5c)}<smiles>CCCCC(=O)c1c(-c2ccccc2)cnc2ccccc12</smiles>

$5 \mathrm{c}$

Following the GP5, starting from tert-butyl 1,2-diphenylcycloprop-2-ene-1-carboxylate (4c) (58.5 mg, $200 \mu \mathrm{mol}, 1.00$ equiv) the title compound $\mathbf{5 c}$ was obtained after purification by column chromatography ( $\mathrm{SiO}_{2}$, EtOAc:Pentane 10:90) as a yellow oil (23.0 mg, $75.3 \mu \mathrm{mol}$, $38 \%$ yield). 
$\mathrm{Rf}=0.39$ (EtOAc:Pentane 1:9). ${ }^{1} \mathrm{H}$ NMR $\left(400 \mathrm{MHz}, \mathrm{CDCl}_{3}\right) \delta 8.89(\mathrm{~s}, 1 \mathrm{H}, \mathrm{ArH}), 8.10$ (ddd, $J$ $=8.4,1.3,0.6 \mathrm{~Hz}, 1 \mathrm{H}, \mathrm{Ar} H), 7.91(\mathrm{ddd}, J=8.4,1.4,0.7 \mathrm{~Hz}, 1 \mathrm{H} \mathrm{ArH}), 7.69$ (ddd, $J=8.4,6.9$, $1.4 \mathrm{~Hz}, 1 \mathrm{H}, \operatorname{Ar} H$ ), 7.56 (ddd, $J=8.3,6.9,1.3 \mathrm{~Hz}, 1 \mathrm{H}, \mathrm{Ar} H$ ), $7.48-7.31$ (m, 5H, ArH), 1.29 $(\mathrm{s}, 9 \mathrm{H}, \mathrm{CH} 3) .{ }^{13} \mathrm{C} \mathrm{NMR}\left(101 \mathrm{MHz}, \mathrm{CDCl}_{3}\right) \delta 166.4,151.4,147.3,138.4,137.3,131.3,129.8$, 129.6, 129.3, 128.6, 128.2, 127.9, 124.9, 123.8, 83.5, 27.8. IR $\left(v_{\max }, \mathrm{cm}^{-1}\right) 3061(\mathrm{~m}), 2979(\mathrm{~m})$, 2935 (m), 1722 (s), 1608 (w), 1575 (w), 1494 (m), 1455 (m), 1375 (m), 1321 (m), 1263 (s), 1163 (s), 1096 (w), 1021 (m), 909 (m), 845 (m), 801 (m), 765 (s), 705 (m), 645 (w). HRMS (ESI/QTOF) m/z: [M + H] $]^{+}$Calcd for $\mathrm{C}_{20} \mathrm{H}_{20} \mathrm{NO}_{2}{ }^{+}$306.1489; Found 306.1488.

\section{Methyl quinoline-4-carboxylate (5d)}<smiles>CC(=O)c1ccnc2ccccc12</smiles>

Following the GP6, starting from methyl 1-phenylcycloprop-2-ene-1-carboxylate (4d) (34.8 mg, $200 \mu \mathrm{mol}, 1.00$ equiv) the title compound 5d was obtained after purification by column chromatography ( $\mathrm{SiO}_{2}$, EtOAc:Pentane 10:90) as a yellow oil (15.0 mg, $80.1 \mu \mathrm{mol}, 40 \%$ yield). $\mathrm{Rf}=0.24$ (EtOAc:Pentane 1:9). ${ }^{1} \mathrm{H}$ NMR $\left(400 \mathrm{MHz}, \mathrm{CDCl}_{3}\right) \delta 9.03(\mathrm{~d}, J=4.5 \mathrm{~Hz}, 1 \mathrm{H}, \mathrm{ArH})$, $\delta 8.77(\mathrm{dd}, J=8.5,0.8 \mathrm{~Hz}, 1 \mathrm{H}, \operatorname{Ar} H), 8.18(\mathrm{dd}, J=8.5,1.0 \mathrm{~Hz}, 1 \mathrm{H}, \operatorname{Ar} H), 7.91(\mathrm{~d}, J=4.5 \mathrm{~Hz}$, $1 \mathrm{H}, \mathrm{ArH}), 7.80-7.76(\mathrm{~m}, 1 \mathrm{H}, \mathrm{ArH}), 7.68-7.65(\mathrm{~m}, 1 \mathrm{H}, \mathrm{ArH}), 4.05$ (s, 3H, CH3). Spectral data of the obtained compound is corresponding to the reported values ${ }^{19}$.

\section{4-Phenylquinoline (5e)}<smiles>O=S(=O)(c1ccccc1)c1ccccc1-c1ccccc1</smiles>

Following the GP5, starting from 3,3-diphenylcyclopropene (4e) $(38.5 \mathrm{mg}, 200 \mu \mathrm{mol}, 1.00$ equiv) the title compound $\mathbf{5 e}$ was obtained after purification by column chromatography $\left(\mathrm{SiO}_{2}\right.$, EtOAc:Pentane 5:95 to 20:80) as a white solid (28.1 mg, $137 \mu \mathrm{mol}, 68 \%$ yield).

$\mathrm{Rf}=0.2$ (Pentane:Et $2 \mathrm{O} 6: 4) .{ }^{1} \mathrm{H}$ NMR $\left(400 \mathrm{MHz}, \mathrm{CDCl}_{3}\right) \delta 8.94(\mathrm{~d}, J=4.6 \mathrm{~Hz}, 1 \mathrm{H}, \mathrm{ArH}), 8.18$ $(\mathrm{dd}, J=8.5,1.4 \mathrm{~Hz}, 1 \mathrm{H}, \mathrm{ArH}), 7.92(\mathrm{dd}, J=8.5,1.4 \mathrm{~Hz}, 1 \mathrm{H}, \operatorname{Ar} H), 7.75-7.69$ (m, 1H, ArH), $7.56-7.45(\mathrm{~m}, 6 \mathrm{H}, \operatorname{ArH}), 7.33(\mathrm{~d}, J=4.6 \mathrm{~Hz}, 1 \mathrm{H}, \mathrm{ArH})$. Spectral data of the obtained compound is corresponding to the reported values ${ }^{20}$.

\section{7-Chloro-4-(4-chlorophenyl)quinoline (5f)}<smiles>Clc1ccc(-c2ccnc3cc(Cl)ccc23)cc1</smiles>

\footnotetext{
${ }^{19}$ A. Chatterjee, B. König, Angew. Chem. Int. Ed. 2019, 58, 14289.

${ }^{20}$ Choy, P. Y.; Yuen, O. Y.; Leung, M. P.; Chow, W. K.; Kwong, F. Y., Eur. J. Org. Chem. 2020.
} 
Following the GP5, starting from 4,4'-(cycloprop-2-ene-1,1-diyl)bis(chlorobenzene) (4f)

(52.2 $\mathrm{mg}, 200 \mu \mathrm{mol}, 1.00$ equiv) the title compound $\mathbf{5 f}$ was obtained after purification by column chromatography ( $\mathrm{SiO}_{2}$, EtOAc:Pentane 5:95 to 20:80) as a white solid (44.3 mg, 0.162 mmol, $81 \%$ yield).

$\mathrm{Rf}=0.36$ (EtOAc:Pentane 1:9). ${ }^{1} \mathrm{H}-\mathrm{NMR}\left(\mathrm{CDCl}_{3}, 400 \mathrm{MHz}\right) \delta 8.94(\mathrm{~d}, J=4.30 \mathrm{~Hz}, 1 \mathrm{H}, \mathrm{Ar} H)$, $8.18(\mathrm{~s}, 1 \mathrm{H}, \operatorname{Ar} H), 7.80(\mathrm{~d}, J=9.04 \mathrm{~Hz}, 1 \mathrm{H}, \operatorname{Ar} H), 7.52(\mathrm{~d}, J=8.10 \mathrm{~Hz}, 2 \mathrm{H}, \operatorname{Ar} H), 7.46(\mathrm{~d}, J$ $=9.04 \mathrm{~Hz}, 1 \mathrm{H}, \operatorname{Ar} H), 7.42(\mathrm{~d}, J=8.10 \mathrm{~Hz}, 2 \mathrm{H}, \operatorname{Ar} H), 7.31(\mathrm{~d}, J=4.30 \mathrm{~Hz}, 1 \mathrm{H}, \operatorname{Ar} H)$. Spectral data of the obtained compound is corresponding to the reported values ${ }^{21}$.

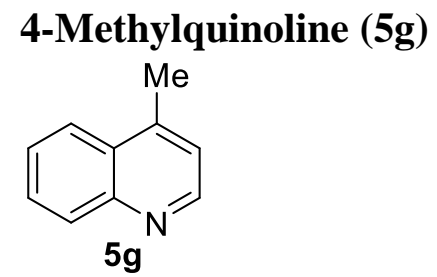

Following the GP5, starting from (1-methylcycloprop-2-en-1-yl)benzene (4g) (26.0 mg, 200 $\mu \mathrm{mol}, 1.00$ equiv) the title compound $\mathbf{5 g}$ was obtained after purification by column chromatography ( $\mathrm{SiO}_{2}$, EtOAc:Pentane 20:80) as a light-yellow oil (11.9 mg, $83.1 \mu \mathrm{mol}, 42 \%$ yield).

$\mathrm{Rf}=0.40$ (Pentane:EtOAc 9:1). ${ }^{1} \mathrm{H}$ NMR $\left(400 \mathrm{MHz}, \mathrm{CDCl}_{3}\right) \delta 8.78(\mathrm{~d}, J=4.4 \mathrm{~Hz}, 1 \mathrm{H}, \mathrm{Ar} H)$, $8.11(\mathrm{~d}, J=8.5 \mathrm{~Hz}, 1 \mathrm{H}, \mathrm{ArH}), 8.00(\mathrm{dd}, J=8.3,0.9 \mathrm{~Hz}, 1 \mathrm{H}, \mathrm{ArH}), 7.71$ (ddd, $J=8.4,6.8,1.4$ $\mathrm{Hz}, 1 \mathrm{H}, \operatorname{Ar} H$ ), 7.57 (ddd, $J=8.2,7.0,1.2 \mathrm{~Hz}, 1 \mathrm{H}, \operatorname{ArH}), 7.23(\mathrm{dd}, J=4.4,1.2 \mathrm{~Hz}, 1 \mathrm{H}, \operatorname{Ar} H$ ), $2.71\left(\mathrm{~s}, 3 \mathrm{H}, \mathrm{CH}_{3}\right)$. Spectral data of the obtained compound is corresponding to the reported values $^{22}$.

\section{3-Phenyl-4-(trifluoromethyl)quinoline (5h)}<smiles>FC(F)(F)c1c(-c2ccccc2)cnc2ccccc12</smiles>

$5 \mathrm{~h}$

Following the GP5, starting from (1-(trifluoromethyl)cycloprop-2-ene-1,2-diyl)dibenzene (4h) (52.1 $\mathrm{mg}, 200 \mu \mathrm{mol}, 1.00$ equiv) the title compound $\mathbf{5 h}$ was obtained after purification by column chromatography ( $\mathrm{SiO}_{2}$, EtOAc:Pentane 5:95 to 20:80) as a yellow oil (32.0 $\mathrm{mg}, 117$ $\mu \mathrm{mol}, 59 \%$ yield). ${ }^{1} \mathrm{H}$ NMR (400 MHz, $\left.\mathrm{CDCl}_{3}\right): \delta 8.87(\mathrm{~s}, 1 \mathrm{H}, \mathrm{ArH}), 8.27(\mathrm{~d}, J=8.6 \mathrm{~Hz}, 1 \mathrm{H}$, $\mathrm{ArH}), 8.24(\mathrm{~d}, J=8.6 \mathrm{~Hz}, 1 \mathrm{H}, \mathrm{ArH}), 7.80-7.83$ (m, 1H, ArH), 7.70-7.73 (m, 1H, ArH), 7.46$7.50(\mathrm{~m}, 3 \mathrm{H}, \mathrm{ArH}), 7.38(\mathrm{dd}, J=7.4,1.7 \mathrm{~Hz}, 2 \mathrm{H}, \mathrm{Ar} H)$. Spectral data of the obtained compound is corresponding to the reported values ${ }^{23}$.

\section{3-(4-Methoxyphenyl)-4-(trifluoromethyl)quinoline (5i)}

\footnotetext{
21 Jiang, H.; An, X.; Tong, K.; Zheng, T.; Zhang, Y.; Yu, S., Angew. Chem. Int. Ed. 2015, 54 (13), 4055-4059.

22 Sahoo, M. K.; Jaiswal, G.; Rana, J.; Balaraman, E., Chem. Eur. J. 2017, 23 (57), 14167-14172.

${ }^{23}$ Nagase, M.; Kuninobu, Y.; Kanai, M., J. Am. Chem. Soc. 2016, 138 (19), 6103-6106.
} 
<smiles>COc1ccc(-c2cnc3ccccc3c2C(F)(F)F)cc1</smiles>

Following the GP5, starting from 1-methoxy-4-(3-phenyl-3-(trifluoromethyl)cycloprop-1-en1-yl)benzene (5i) $(58.1 \mathrm{mg}, 200 \mu \mathrm{mol}, 1.00$ equiv) the title compound $\mathbf{5 i}$ was obtained after purification by column chromatography $\left(\mathrm{SiO}_{2}, \mathrm{Et}_{2} \mathrm{O}\right.$ :Pentane 1:99 to 10:90) as a light-yellow oil (34.4 mg, $0.113 \mathrm{mmol}, 59 \%$ yield).

$\mathrm{Rf}=0.22$ (Pentane:Et $2 \mathrm{O} 9: 1) .{ }^{1} \mathrm{H}$ NMR $\left(400 \mathrm{MHz} \mathrm{CDCl}_{3}\right) \delta 8.87(\mathrm{~s}, 1 \mathrm{H}, \mathrm{ArH}), 8.30-8.18(\mathrm{~m}$, $2 \mathrm{H}, \operatorname{Ar} H), 7.80(\mathrm{ddd}, J=8.3,6.8,1.4 \mathrm{~Hz}, 1 \mathrm{H}, \mathrm{Ar} H), 7.70(\mathrm{ddd}, J=8.5,6.9,1.4 \mathrm{~Hz}, 1 \mathrm{H}, \operatorname{Ar} H)$, $7.35-7.27(\mathrm{~m}, 2 \mathrm{H}, \mathrm{ArH}), 7.06-6.97(\mathrm{~m}, 2 \mathrm{H}, \mathrm{ArH}), 3.89$ (s, 3H, CH3). ${ }^{13} \mathrm{C}$ NMR $(101 \mathrm{MHz}$, $\left.\mathrm{CDCl}_{3}\right) \delta 159.7,153.3,147.9,133.7(\mathrm{q}, J=2.9 \mathrm{~Hz}), 130.7(\mathrm{q}, J=29.6 \mathrm{~Hz}), 130.3,130.2$, $129.9,129.7,128.4,124.9(\mathrm{q}, J=3.9 \mathrm{~Hz}), 124.8(\mathrm{q}, J=277.9 \mathrm{~Hz}) 123.4,113.8,55.4 .{ }^{19} \mathrm{~F} \mathrm{NMR}$ $\left(376 \mathrm{MHz}, \mathrm{CDCl}_{3}\right) \delta$-52.2. IR $\left(v_{\max }, \mathrm{cm}^{-1}\right) 3135(\mathrm{w}), 3059(\mathrm{w}), 2935(\mathrm{w}), 2851(\mathrm{w}), 1951(\mathrm{w})$, $1765(\mathrm{w}), 1596(\mathrm{w}), 1503(\mathrm{w}), 1302(\mathrm{~m}), 1249(\mathrm{~m}), 1162(\mathrm{~s}), 1126(\mathrm{~s}), 1042(\mathrm{w}), 978(\mathrm{w}), 920$ (m), $801(\mathrm{~m}), 770(\mathrm{~m}), 703(\mathrm{~m}), 653(\mathrm{~m})$. HRMS (ESI/QTOF) m/z: [M + H] ${ }^{+}$Calcd for $\mathrm{C}_{22} \mathrm{H}_{15} \mathrm{~F}_{3} \mathrm{~N}^{+} 350.1151$; Found 350.1147 .

\section{Methyl 4-(4-(trifluoromethyl)quinolin-3-yl)benzoate (5j)}<smiles>CC(=O)c1ccc(-c2cnc3ccccc3c2C(F)(F)F)cc1</smiles>

$5 \mathbf{j}$

Following the GP5, starting from methyl 4-(3-phenyl-3-(trifluoromethyl)cycloprop-1-en-1yl)benzoate (5j) $(63.7 \mathrm{mg}, 200 \mu \mathrm{mol}, 1.00$ equiv) the title compound $\mathbf{5 j}$ was obtained after purification by column chromatography ( $\mathrm{SiO}_{2}$, EtOAc:Pentane 5:95 to 20:80) as a yellow oil (42 mg, $0.12 \mathrm{mmol}, 63 \%$ yield).

$\mathrm{Rf}=0.3$ (EtOAc:Pentane 1:9). ${ }^{1} \mathrm{H}$ NMR $\left(400 \mathrm{MHz}, \mathrm{CDCl}_{3}\right) \delta 8.83(\mathrm{~s}, 1 \mathrm{H}, \mathrm{ArH}), 8.25$ (td, $J=$ 8.9, 8.3, 1.7 Hz, 2H, ArH), 8.19-8.08 (m, 2H, ArH), 7.84 (ddd, $J=8.2,6.8,1.4 \mathrm{~Hz}, 1 \mathrm{H}, \operatorname{ArH}$ ), 7.73 (ddd, $J=8.5,6.9,1.4 \mathrm{~Hz}, 1 \mathrm{H}, \mathrm{ArH}), 7.49-7.40(\mathrm{~m}, 2 \mathrm{H}, \mathrm{ArH}), 3.97\left(\mathrm{~s}, 3 \mathrm{H}, \mathrm{CH}_{3}\right) .{ }^{13} \mathrm{C}$ $\operatorname{NMR}\left(101 \mathrm{MHz}, \mathrm{CDCl}_{3}\right) \delta 166.6,152.0,148.3,142.3,132.7,130.8(\mathrm{q}, J=30.0 \mathrm{~Hz}), 130.4$, 130.2, 130.1, 129.5, 129.1 (q, $J=1.9 \mathrm{~Hz}), 128.7,124.9$ (q, $J=3.7 \mathrm{~Hz}), 123.8$ (q, 276Hz), 52.3.(one carbon is not resolved). ${ }^{19} \mathrm{~F}$ NMR $\left(376 \mathrm{MHz}, \mathrm{CDCl}_{3}\right) \delta-52.2$. IR $\left(v_{\max }, \mathrm{cm}^{-1}\right) 3002$ (w), $2953(\mathrm{w}), 2899(\mathrm{w}), 2846(\mathrm{w}), 2256(\mathrm{w}), 2113(\mathrm{w}), 1724(\mathrm{~s}), 1612(\mathrm{~m}), 1568(\mathrm{w}), 1502$ (m), $1461(\mathrm{~m}), 1437(\mathrm{~m}), 1404(\mathrm{~m}), 1386(\mathrm{~m}), 1325(\mathrm{~m}), 1277$ (s), $1264(\mathrm{~s}), 1227(\mathrm{~m}), 1213$ (m), $1174(\mathrm{~s}), 1151(\mathrm{~m}), 1129(\mathrm{~s}), 1021(\mathrm{~m}), 985(\mathrm{~m}), 966(\mathrm{w}), 908(\mathrm{~s}), 887(\mathrm{~m}), 858(\mathrm{~m}), 826$ (w), 775 (m), 765 (m), 732 (s), 709 (s), 652 (s), 624 (w). HRMS (ESI/QTOF) m/z: [M + $\mathrm{H}]^{+}$Calcd for $\mathrm{C}_{18} \mathrm{H}_{13} \mathrm{~F}_{3} \mathrm{NO}_{2}{ }^{+}$332.0893; Found 332.0903.

\section{3-(3-Fluorophenyl)-4-(trifluoromethyl)quinoline (5k)}


<smiles>Fc1cccc(-c2cnc3ccccc3c2C(F)(F)F)c1</smiles>

$5 k$

Following the GP5, starting from 1-fluoro-3-(3-phenyl-3-(trifluoromethyl)cycloprop-1-en-1yl)benzene (4k) $(55.7 \mathrm{mg}, 200 \mu \mathrm{mol}, 1.00$ equiv) the title compound 5k was obtained after purification by column chromatography $\left(\mathrm{SiO}_{2}\right.$, EtOAc:Pentane 5:95) as a light-yellow oil (34.5 mg, $118 \mu \mathrm{mol}, 59 \%$ yield).

Rf=0.39 (pentane:EtOAc(19:1). ${ }^{1} \mathrm{H}$ NMR $\left(400 \mathrm{MHz}, \mathrm{CDCl}_{3}\right) \delta 8.84(\mathrm{~s}, 1 \mathrm{H}, \mathrm{ArH}), 8.26(\mathrm{td}, J$ $=8.4,1.7 \mathrm{~Hz}, 2 \mathrm{H}, \mathrm{ArH}), 7.84(\mathrm{ddd}, J=8.3,6.9,1.4 \mathrm{~Hz}, 1 \mathrm{H}, \mathrm{ArH}), 7.73$ (ddd, $J=8.5,6.9,1.4$ $\mathrm{Hz}, 1 \mathrm{H}, \operatorname{Ar} H), 7.50-7.37(\mathrm{~m}, 1 \mathrm{H}, \operatorname{Ar} H), 7.22-7.05(\mathrm{~m}, 3 \mathrm{H}, \operatorname{ArH}) .{ }^{13} \mathrm{C}$ NMR $(101 \mathrm{MHz}$, $\left.\mathrm{CDCl}_{3}\right) \delta 162.4(\mathrm{~d}, J=247.5 \mathrm{~Hz}), 152.2,148.3,139.7(\mathrm{~d}, J=8.0 \mathrm{~Hz}), 132.4,130.9(\mathrm{q}, J=$ $29.7 \mathrm{~Hz}), 130.4,130.2,129.9(\mathrm{~d}, J=8.4 \mathrm{~Hz}), 128.7,125.0-124.7(\mathrm{~m})(2 \mathrm{C}), 123.8(\mathrm{q}, J=278.0$ $\mathrm{Hz}), 123.1,116.1(\mathrm{dq}, J=22.5,1.8 \mathrm{~Hz}), 115.3(\mathrm{~d}, J=21.1 \mathrm{~Hz}) .{ }^{19} \mathrm{~F} \mathrm{NMR}\left(376 \mathrm{MHz}, \mathrm{CDCl}_{3}\right)$ $\delta$-52.3, -112.8. IR ( $\left.v_{\max }, \mathrm{cm}^{-1}\right) 3073(\mathrm{w}), 1606(\mathrm{w}), 1587(\mathrm{~m}), 1496(\mathrm{~m}), 1441(\mathrm{w}), 1387(\mathrm{w})$, $1328(\mathrm{~m}), 1270(\mathrm{~m}), 1227(\mathrm{~m}), 1167(\mathrm{~s}), 1130(\mathrm{~s}), 997(\mathrm{w}), 930(\mathrm{w}), 876(\mathrm{w}), 830(\mathrm{~m}), 768(\mathrm{~m})$, $696(\mathrm{~m}), 638(\mathrm{w}) . \mathrm{HRMS}(\mathrm{ESI} / \mathrm{QTOF}) \mathrm{m} / \mathrm{z}:[\mathrm{M}+\mathrm{H}]^{+}$Calcd for $\mathrm{C}_{16} \mathrm{H}_{10} \mathrm{~F}_{4} \mathrm{~N}^{+}$292.0744; Found 292.0745 .

\section{7-Bromo-3-phenyl-4-(trifluoromethyl)quinoline (5l)}<smiles>FC(F)(F)c1c(-c2ccccc2)cnc2cc(Br)ccc12</smiles>

51

Following the GP5, starting from 1-bromo-4-(2-phenyl-1-(trifluoromethyl)cycloprop-2-en-1yl)benzene (4l) (33.9 mg, $100 \mu \mathrm{mol}, 1.00$ equiv) the title compound $\mathbf{5 l}$ was obtained after purification by preparative TLC ( $\mathrm{SiO}_{2}$, Toluene:Pentane 50:50) as a light-yellow oil (19.1 mg, $54.2 \mu \mathrm{mol}, 54 \%$ yield).

Rf (pentane:toluene $(1: 1))=0.13 .{ }^{1} \mathrm{H}$ NMR $\left(400 \mathrm{MHz}, \mathrm{CDCl}_{3}\right) \delta 8.86(\mathrm{~s}, 1 \mathrm{H}, \mathrm{ArH}), 8.42(\mathrm{~d}, J$ $=2.1 \mathrm{~Hz}, 1 \mathrm{H}, \mathrm{Ar} H), 8.12(\mathrm{dq}, J=9.2,2.3 \mathrm{~Hz}, 1 \mathrm{H}, \mathrm{Ar} H), 7.80(\mathrm{dd}, J=9.2,2.1 \mathrm{~Hz}, 1 \mathrm{H}, \mathrm{Ar} H)$, $7.54-7.43(\mathrm{~m}, 3 \mathrm{H}, \mathrm{ArH}), 7.41-7.32(\mathrm{~m}, 2 \mathrm{H}, \mathrm{ArH}) .{ }^{13} \mathrm{C} \mathrm{NMR}\left(101 \mathrm{MHz}, \mathrm{CDCl}_{3}\right) \delta 153.9$, $148.7,137.2,134.1,132.6,132.0,130.8$ (q, $J=29 \mathrm{~Hz}), 128.9,128.5,128.3,126.3$ (q, $J=4.1$ $\mathrm{Hz}), 124.1,123.7(\mathrm{q}, J=276 \mathrm{~Hz}), 122.0 .{ }^{19} \mathrm{~F}$ NMR $\left(376 \mathrm{MHz}, \mathrm{CDCl}_{3}\right) \delta-52.2 . \mathrm{IR}\left(v_{\max }, \mathrm{cm}^{-1}\right)$ 3061 (w), 3036 (w), 2952 (w), $2929(\mathrm{w}), 2857$ (w), 1727 (w), $1602(\mathrm{~m}), 1491(\mathrm{~m}), 1445(\mathrm{~m})$, 1394 (m), 1319 (m), $1284(\mathrm{~m}), 1259$ (m), 1226 (m), 1200 (m), 1152 (s), 1128 (s), 1070 (m), $1031(\mathrm{w}), 984(\mathrm{~m}), 940(\mathrm{~m}), 888(\mathrm{~m}), 911(\mathrm{~m}), 853(\mathrm{w}), 828(\mathrm{~m}), 783(\mathrm{~m}), 763(\mathrm{~m}), 736(\mathrm{~m})$, $700(\mathrm{~m}), 659(\mathrm{~m}), 626(\mathrm{~m})$. HRMS (nanochip-ESI/LTQ-Orbitrap) m/z: $[\mathrm{M}+\mathrm{H}]^{+}$Calcd for $\mathrm{C}_{16} \mathrm{H}_{10}{ }^{79} \mathrm{BrF}_{3} \mathrm{~N}^{+}$351.9943; Found 351.9960.

\section{3,7-Diphenyl-4-(trifluoromethyl)quinoline (5m)}


<smiles>FC(F)(F)c1c(-c2ccccc2)cnc2cc(-c3ccccc3)ccc12</smiles>

$5 m$

Following the GP5, starting from methyl 4-(2-phenyl-1-(trifluoromethyl)cycloprop-2-en-1-yl)1,1'-biphenyl (4m) $(67.3 \mathrm{mg}, 200 \mu \mathrm{mol}, 1.00$ equiv) the title compound $\mathbf{5 m}$ was obtained after purification by column chromatography $\left(\mathrm{SiO}_{2}, \mathrm{Et}_{2} \mathrm{O}:\right.$ Pentane $\left.5: 95\right)$ as a white solid $(47.0 \mathrm{mg}$, $0.135 \mathrm{mmol}, 67 \%$ yield).

$\mathrm{Rf}=0.28\left(\mathrm{Et}_{2} \mathrm{O}\right.$ :pentane (1:19)). M.p. $95-97^{\circ} \mathrm{C} .{ }^{1} \mathrm{H}$ NMR $\left(400 \mathrm{MHz}, \mathrm{CDCl}_{3}\right) \delta 8.90(\mathrm{~s}, 1 \mathrm{H}$, $\operatorname{Ar} H), 8.46(\mathrm{~d}, J=2.0 \mathrm{~Hz}, 1 \mathrm{H}, \operatorname{Ar} H), 8.34(\mathrm{dq}, J=9.0,2.5 \mathrm{~Hz}, 1 \mathrm{H}, \operatorname{Ar} H), 8.01(\mathrm{dd}, J=9.0$, $2.0 \mathrm{~Hz}, 1 \mathrm{H}, \mathrm{Ar} H), 7.81(\mathrm{dd}, J=7.4,1.8 \mathrm{~Hz}, 2 \mathrm{H}, \mathrm{Ar} H), 7.59-7.34(\mathrm{~m}, 8 \mathrm{H}, \mathrm{Ar} H) .{ }^{13} \mathrm{C} \mathrm{NMR}$ $\left(101 \mathrm{MHz}, \mathrm{CDCl}_{3}\right) \delta 153.3,148.5,142.5,139.4,137.7,133.6,130.5(\mathrm{q}, J=29.9 \mathrm{~Hz}), 129.2$, 129.0, 128.4, 128.3, 128.0, 127.7, 127.5, 125.4 (q, $J=3.9 \mathrm{~Hz}), 124.0$ (q, 276Hz), 122.3.(one carbon is not resolved). ${ }^{19} \mathrm{~F} \mathrm{NMR}\left(376 \mathrm{MHz}, \mathrm{CDCl}_{3}\right) \delta-52.2$. IR $\left(v_{\max }, \mathrm{cm}^{-1}\right) 3058(\mathrm{w}), 3035$ (w), $2955(\mathrm{w}), 2925(\mathrm{w}), 2857(\mathrm{w}), 2116(\mathrm{w}), 1956(\mathrm{w}), 1887(\mathrm{w}), 1804(\mathrm{w}), 1727(\mathrm{w}), 1682$ (w), $1613(\mathrm{w}), 1492(\mathrm{~m}), 1438(\mathrm{w}), 1395(\mathrm{w}), 1330(\mathrm{~m}), 1276(\mathrm{~m}), 1237(\mathrm{~m}), 1190(\mathrm{~m}), 1124$ (s), $1082(\mathrm{~m}), 1026(\mathrm{w}), 992(\mathrm{w}), 904(\mathrm{~m}), 829(\mathrm{w}), 800(\mathrm{w}), 762(\mathrm{~s}), 734(\mathrm{~m}), 694(\mathrm{~s}), 651(\mathrm{w})$, 610 (w). HRMS (ESI/QTOF) m/z: [M+H] ${ }^{+}$Calcd for $\mathrm{C}_{22} \mathrm{H}_{15} \mathrm{~F}_{3} \mathrm{~N}^{+} 350.1151$; Found 350.1147 .

\section{3-Propyl-4-(trifluoromethyl)quinoline (5n)}<smiles>CCCc1cnc2ccccc2c1C(F)(F)F</smiles>

$5 n$

Following the GP6, starting from (2-propyl-1-(trifluoromethyl)cycloprop-2-en-1-yl)benzene (4n) $(45.3 \mathrm{mg}, 200 \mu \mathrm{mol}, 1.00$ equiv) the title compound $\mathbf{5 n}$ was obtained after purification by column chromatography $\left(\mathrm{SiO}_{2}, \mathrm{Et}_{2} \mathrm{O}:\right.$ Pentane $1: 99$ to $\left.10: 90\right)$ as a yellow oil (16.5 mg, 0.0690 mmol, 34\% yield).

$\mathrm{Rf}=0.25\left(\mathrm{Et}_{2} \mathrm{O}:\right.$ Pentane 1:19). ${ }^{1} \mathrm{H}$ NMR $\left(400 \mathrm{MHz}, \mathrm{CDCl}_{3}\right) \delta 8.81(\mathrm{~s}, 1 \mathrm{H}, \mathrm{ArH}), 8.22-8.11$ (m, 2H, ArH), 7.73 (ddd, $J=8.4,6.8,1.3 \mathrm{~Hz}, 1 \mathrm{H}, \operatorname{Ar} H$ ), 7.63 (ddd, $J=8.4,6.9,1.4 \mathrm{~Hz}, 1 \mathrm{H}$, $\mathrm{ArH}$ ), 3.00 (ddq, $\left.J=10.4,4.8,2.3 \mathrm{~Hz}, 2 \mathrm{H}, \mathrm{ArCH}_{2}\right), 1.77-1.65\left(\mathrm{~m}, 2 \mathrm{H}, \mathrm{CH}_{2} \mathrm{CH}_{2} \mathrm{CH}_{3}\right), 1.04$ $\left(\mathrm{t}, J=7.3 \mathrm{~Hz}, 3 \mathrm{H}, \mathrm{CH}_{3}\right) .{ }^{13} \mathrm{C} \mathrm{NMR}\left(101 \mathrm{MHz}, \mathrm{CDCl}_{3}\right) \delta 154.2,147.5,133.9,130.6(\mathrm{q}, J=$ $29.7 \mathrm{~Hz}), 130.2,129.1,128.0,124.9(\mathrm{q}, J=278.0 \mathrm{~Hz}), 124.4(\mathrm{q}, J=4.3 \mathrm{~Hz}), 123.7,34.5(\mathrm{q}, J$ $=3.9 \mathrm{~Hz}), 25.5,14.1 .{ }^{19} \mathrm{~F}$ NMR $\left(376 \mathrm{MHz}, \mathrm{CDCl}_{3}\right) \delta-53.7$. HRMS (ESI/QTOF) m/z: $[\mathrm{M}+$ $\mathrm{H}]^{+}$Calcd for $\mathrm{C}_{13} \mathrm{H}_{13} \mathrm{~F}_{3} \mathrm{~N}^{+}$240.0995; Found 240.0994.

\section{2-Ethyl-3-phenyl-4-(trifluoromethyl)quinoline (5o)}<smiles>CCc1nc2ccccc2c(C(F)(F)F)c1-c1ccccc1</smiles>

50 
Following the GP6, starting from (3-ethyl-1-(trifluoromethyl)cycloprop-2-ene-1,2diyl)dibenzene (4o) $(57.7 \mathrm{mg}, 200 \mu \mathrm{mol}, 1.00$ equiv) the title compound 50 was obtained after purification by column chromatography $\left(\mathrm{SiO}_{2}, \mathrm{Et}_{2} \mathrm{O}:\right.$ Pentane 1:99 to 10:90) as a white solid (27.4 mg, $0.0909 \mathrm{mmol}, 45 \%$ yield).

$\mathrm{Rf}=0.91$ (EtOAc:Pentane 10:90). M.p. 59-61 ${ }^{\circ} \mathrm{C} .{ }^{1} \mathrm{H}$ NMR $\left(400 \mathrm{MHz}, \mathrm{CDCl}_{3}\right) \delta 8.11$ (ddd, $J=$ 9.9, 7.8, $1.7 \mathrm{~Hz}, 2 \mathrm{H}, \operatorname{Ar} H$ ), 7.69 (ddd, $J=8.3,6.8,1.3 \mathrm{~Hz}, 1 \mathrm{H}, \operatorname{Ar} H$ ), 7.54 (ddd, $J=8.4,6.9$, $1.4 \mathrm{~Hz}, 1 \mathrm{H}, \operatorname{ArH}), 7.44-7.29$ (m, 3H, $\operatorname{ArH}), 7.19-7.12$ (m, 2H, ArH), 2.59 (q, J = $7.5 \mathrm{~Hz}$, $\left.2 \mathrm{H}, \mathrm{CH}_{2}\right), 1.11(\mathrm{t}, J=7.5 \mathrm{~Hz}, 3 \mathrm{H}, \mathrm{CH}) .{ }^{13} \mathrm{C} \mathrm{NMR}\left(101 \mathrm{MHz}, \mathrm{CDCl}_{3}\right) \delta 163.0,147.9,137.4$, $133.4,131.3(\mathrm{q}, J=28.6 \mathrm{~Hz}), 129.9,129.6,128.6,128.2,127.8,127.4,124.8(\mathrm{q}, J=4.1 \mathrm{~Hz})$, 124.1(q, 277Hz), 122.0, 30.3, 13.2. ${ }^{19} \mathrm{~F}$ NMR $\left(376 \mathrm{MHz}, \mathrm{CDCl}_{3}\right) \delta$-51.6. IR $\left(v_{\max }, \mathrm{cm}^{-1}\right) 3063$ (w), 2979 (w), 2936 (w), $2877(w), 1607$ (w), $1570(\mathrm{w}), 1496(\mathrm{w}), 1452$ (w), $1389(\mathrm{~m}), 1329$ (m), 1229 (s), 1174 (s), 1123 (s), 1076 (w), 913 (w), 859 (w), 762 (m), 708 (m), 639 (w). HRMS (ESI/QTOF) $\mathrm{m} / \mathrm{z}$ : $[\mathrm{M}+\mathrm{H}]^{+}$Calcd for $\mathrm{C}_{18} \mathrm{H}_{15} \mathrm{~F}_{3} \mathrm{~N}^{+} 302.1151$; Found 302.1158. The structure was confirmed by HMBC spectrum.

\section{2,3-Diphenyl-4-(trifluoromethyl)quinoline (5p)}<smiles>FC(F)(F)c1c(-c2ccccc2)c(-c2ccccc2)nc2ccccc12</smiles>

Following the GP6, starting from (3-(trifluoromethyl)cycloprop-1-ene-1,2,3-triyl)tribenzene (4p) $(67.3 \mathrm{mg}, 200 \mu \mathrm{mol}, 1.00$ equiv) the title compound $\mathbf{5 p}$ was obtained after purification by column chromatography $\left(\mathrm{SiO}_{2}, \mathrm{Et}_{2} \mathrm{O}:\right.$ Pentane $1: 99$ to $\left.10: 90\right)$ as a white solid (49.1 mg, 0.141 mmol, $70 \%$ yield).

$\mathrm{Rf}=0.82$ (EtOAc:Pentane 10:90). M.p. $131-134^{\circ} \mathrm{C} .{ }^{1} \mathrm{H}$ NMR $\left(400 \mathrm{MHz}, \mathrm{CDCl}_{3}\right) \delta 8.29$ (dd, $J=$ 8.3, $1.5 \mathrm{~Hz}, 2 \mathrm{H}, \operatorname{Ar} H$ ), 7.83 (ddd, $J=8.5,6.9,1.3 \mathrm{~Hz}, 1 \mathrm{H}, \mathrm{Ar} H), 7.71$ (ddd, $J=8.4,6.9,1.4$ $\mathrm{Hz}, 1 \mathrm{H}, \operatorname{Ar} H), 7.30-7.16(\mathrm{~m}, 8 \mathrm{H}, \operatorname{Ar} H), 7.15-7.09(\mathrm{~m}, 2 \mathrm{H}, \operatorname{Ar} H) .{ }^{13} \mathrm{C}$ NMR $(101 \mathrm{MHz}$, $\left.\mathrm{CDCl}_{3}\right) \delta 160.1,147.8,140.1,137.2,133.4,132.1(\mathrm{q}, J=29.1 \mathrm{~Hz}), 130.6,130.0,130.0,129.6$, $128.2,127.8,127.7,127.6,126.8(\mathrm{q}, J=277 \mathrm{~Hz}), 124.9(\mathrm{q}, J=4.3 \mathrm{~Hz}), 122.7$.(one carbon is not resolved). ${ }^{19} \mathrm{~F}$ NMR (376 MHz, $\left.\mathrm{CDCl}_{3}\right) \delta$-51.1. IR ( $\left.v_{\max }, \mathrm{cm}^{-1}\right) 3086(\mathrm{w}), 3060(\mathrm{~m}), 3030$ (w), $2112(\mathrm{w}), 1951(\mathrm{w}), 1882(\mathrm{w}), 1805(\mathrm{w}), 1719(\mathrm{w}), 1603(\mathrm{w}), 1580(\mathrm{w}), 1556(\mathrm{~m}), 1496$ (m), 1443 (m), 1399 (m), 1379 (m), 1343 (m), 1309 (m), 1278 (m), 1248 (m), 1227 (m), 1207 (s), 1171 (s), 1148 (s), 1119 (s), 1075 (m), 1032 (m), 989 (w), 909 (m), 855 (w), 761 (s), 730 (s), 697 (s), 645 (s). HRMS (ESI/QTOF) m/z: $[\mathrm{M}+\mathrm{H}]^{+}$Calcd for $\mathrm{C}_{22} \mathrm{H}_{15} \mathrm{~F}_{3} \mathrm{~N}^{+}$350.1151; Found 350.1149 .

6,8-Dichloro-3-(thiophen-3-yl)-4-(trifluoromethyl)quinoline (5q)<smiles>FC(F)(F)c1c(-c2ccsc2)cnc2c(Cl)cc(Cl)cc12</smiles>

Following the GP6, starting from 3-(3-(3,5-dichlorophenyl)-3-(trifluoromethyl)cycloprop-1en-1-yl)thiophene (4q) $(67.0 \mathrm{mg}, 200 \mu \mathrm{mol}, 1.00$ equiv) the title compound $\mathbf{5 q}$ was obtained after purification by column chromatography $\left(\mathrm{SiO}_{2}, \mathrm{Et}_{2} \mathrm{O}\right.$ :Pentane 1:99 to 10:90) as a white solid (32.6 mg, $93.6 \mu \mathrm{mol}, 47 \%$ yield). 
$\mathrm{Rf}=0.45\left(\mathrm{Et}_{2} \mathrm{O}:\right.$ Pentane 1:19). M.p. $152-153^{\circ} \mathrm{C} .{ }^{1} \mathrm{H}$ NMR $\left(400 \mathrm{MHz}, \mathrm{CDCl}_{3}\right) \delta 9.00(\mathrm{~s}, 1 \mathrm{H}$, $\operatorname{Ar} H), 8.15(\mathrm{p}, J=2.1 \mathrm{~Hz}, 1 \mathrm{H}, \operatorname{Ar} H), 7.92(\mathrm{~d}, J=2.1 \mathrm{~Hz}, 1 \mathrm{H}, \operatorname{Ar} H), 7.47(\mathrm{dd}, J=5.0,3.0 \mathrm{~Hz}$, $1 \mathrm{H}, \operatorname{Ar} H), 7.40(\mathrm{dd}, J=3.0,1.4 \mathrm{~Hz}, 1 \mathrm{H}, \operatorname{Ar} H), 7.17(\mathrm{~d}, J=4.9 \mathrm{~Hz}, 1 \mathrm{H}, \operatorname{Ar} H) .{ }^{13} \mathrm{C}$ NMR $(101$ $\left.\mathrm{MHz}, \mathrm{CDCl}_{3}\right) \delta 153.4,142.9,136.2,135.7,134.2,130.9(\mathrm{q}, J=2.6 \mathrm{~Hz}), 130.8,130.6(\mathrm{q}, J=$ $30.3 \mathrm{~Hz}), 128.7(\mathrm{q}, J=2.2 \mathrm{~Hz}), 126.2,125.2,125.0(\mathrm{q}, J=2.1 \mathrm{~Hz}), 123.4(\mathrm{q}, J=278.0 \mathrm{~Hz})$, $123.0(\mathrm{q}, J=4.4 \mathrm{~Hz}) .{ }^{19} \mathrm{~F}$ NMR $\left(376 \mathrm{MHz}, \mathrm{CDCl}_{3}\right) \delta$-53.0. HRMS (ESI/QTOF) m/z: $[\mathrm{M}+$ $\mathrm{H}]^{+}$Calcd for $\mathrm{C}_{14} \mathrm{H}_{7} \mathrm{Cl}_{2} \mathrm{~F}_{3} \mathrm{NS}^{+}$347.9623; Found 347.9622.

\section{6,8-Dichloro-2,3-diphenyl-4-(trifluoromethyl)quinoline (5r)}<smiles>FC(F)(F)c1c(-c2ccccc2)c(-c2ccccc2)nc2c(Cl)cc(Cl)cc12</smiles>

Following the GP6, starting from (3-(3,5-dichlorophenyl)-3-(trifluoromethyl)cycloprop-1-ene1,2-diyl)dibenzene (4r) $(81.0 \mathrm{mg}, 200 \mu \mathrm{mol}, 1.00$ equiv) the title compound $\mathbf{5 r}$ was obtained after purification by column chromatography $\left(\mathrm{SiO}_{2}, \mathrm{Et}_{2} \mathrm{O}\right.$ :Pentane 1:99 to 10:90) as a white solid (44.9 mg, $107 \mu \mathrm{mol}, 54 \%$ yield).

$\mathrm{Rf}=0.81\left(\mathrm{Et}_{2} \mathrm{O}:\right.$ Pentane 1:19). M.p. $113-115^{\circ} \mathrm{C} .{ }^{1} \mathrm{H}$ NMR $\left(400 \mathrm{MHz}, \mathrm{CDCl}_{3}\right) \delta 8.1$ (p, $J=2.3$ $\mathrm{Hz}, 1 \mathrm{H}, \operatorname{Ar} H), 7.9(\mathrm{~d}, J=2.1 \mathrm{~Hz}, 1 \mathrm{H}, \operatorname{Ar} H), 7.3-7.1(\mathrm{~m}, 8 \mathrm{H}, \operatorname{Ar} H), 7.0(\mathrm{dd}, J=7.9,1.7 \mathrm{~Hz}$, $2 \mathrm{H}, \mathrm{ArH}) .{ }^{13} \mathrm{C} \mathrm{NMR}\left(101 \mathrm{MHz}, \mathrm{CDCl}_{3}\right) \delta 160.4,142.7,139.3,136.4,136.1,135.2(\mathrm{q}, J=2.5$ $\mathrm{Hz}), 133.5,131.9(\mathrm{q}, J=29.2 \mathrm{~Hz}), 130.8,130.0,129.8$ (q, $J=2.2 \mathrm{~Hz}), 128.3,128.1,127.8$, 127.6, 124.3, $123.6(\mathrm{q}, J=278.7 \mathrm{~Hz}), 123.0(\mathrm{q}, J=4.7 \mathrm{~Hz}) .{ }^{19} \mathrm{~F}$ NMR $\left(376 \mathrm{MHz}, \mathrm{CDCl}_{3}\right) \delta-$ 51.0. HRMS (ESI/QTOF) m/z: $[\mathrm{M}+\mathrm{H}]^{+}$Calcd for $\mathrm{C}_{22} \mathrm{H}_{13} \mathrm{Cl}_{2} \mathrm{~F}_{3} \mathrm{~N}^{+} 418.0372$; Found 418.0378 .

\section{4. $1.5 \mathrm{mmol}$ scale procedure}<smiles>FC(F)(F)C1(c2ccccc2)C=C1c1ccccc1</smiles><smiles>FC(F)(F)c1c(-c2ccccc2)cnc2ccccc12</smiles>

DCE was degassed by bubbling Ar through it for $30 \mathrm{~min}$. A $50 \mathrm{~mL}$ test tube, equipped with a stirring bar was charged with ABZ (6) (952 mg, $2.15 \mathrm{mmol}, 1.40$ equiv) and (3-oxo1lambda3,2-benziodoxol-1-yl)acetate ${ }^{18}(94.1 \mathrm{mg}, 307 \mu \mathrm{mol}, 0.200$ equiv). It was capped with the septum and evacuated-refilled with $\mathrm{N}_{2}(3 \mathrm{x})$. A solution of (1-(trifluoromethyl)cycloprop-2ene-1,2-diyl)dibenzene (4h) (400 mg, $1.54 \mathrm{mmol}, 1.00$ equiv) in DCE (15.4 ml) was added to the reaction mixture, followed by pyridine ( $243 \mathrm{mg}, 3.07 \mathrm{mmol}, 2.00$ equiv). The reaction mixture was stirred under blue LED irradiation for $14 \mathrm{~h}$. Then, the reaction mixture was filtered through a small pad of silica $(3 \mathrm{~cm})$, washing the sorbent with EtOAc. The resulting solution was concentrated under vacuum to give crude product, which was purified by flash chromatography ( $\mathrm{SiO}_{2}$, EtOAc:Pentane $5: 95$ to 20:80) to give 3-phenyl-4(trifluoromethyl)quinoline (5h) (263 mg, $963 \mu \mathrm{mol}, 63 \%$ yield) as a yellow oil. 


\section{Control and mechanistic experiments}
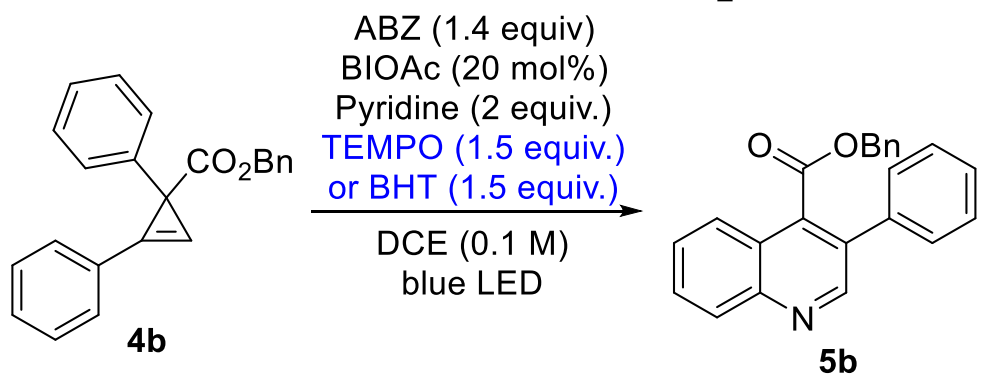

not formed

DCE was degassed by bubbling Ar through it for $30 \mathrm{~min}$. A $5 \mathrm{~mL}$ test tube, equipped with a stirring bar was charged with ABZ (6) (124 mg, $0.280 \mathrm{mmol}, 1.40$ equiv), (3-oxo-1lambda3,2benziodoxol-1-yl)acetate (7) ${ }^{18}(12.2 \mathrm{mg}, 0.0400 \mathrm{mmol}, 0.200$ equiv), radical scavenger (1.5 equiv.), and benzyl 1,2-diphenylcycloprop-2-ene-1-carboxylate (4b) (65.3 mg, $200 \mu \mathrm{mol}, 1.00$ equiv). It was capped with the septum and evacuated-refilled with $\mathrm{N}_{2}(3 \mathrm{x}) .2 \mathrm{~mL}$ of DCE was added to the reaction mixture, followed by pyridine ( $31.6 \mathrm{mg}, 400 \mu \mathrm{mol}, 2.00$ equiv). The reaction mixture was stirred under blue LED irradiation for $14 \mathrm{~h}$. Then, the reaction mixture was filtered through a small pad of silica $(1 \mathrm{~cm})$, washing the sorbent with EtOAc. The resulting solution was concentrated under vacuum to give crude mixture, that does not contain the desired product $\mathbf{5 b}$ as judged by ${ }^{1} \mathrm{H}$ NMR analysis.<smiles></smiles>

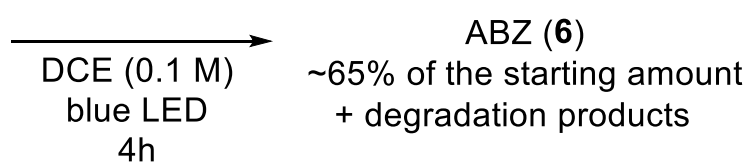

ABZ (6)

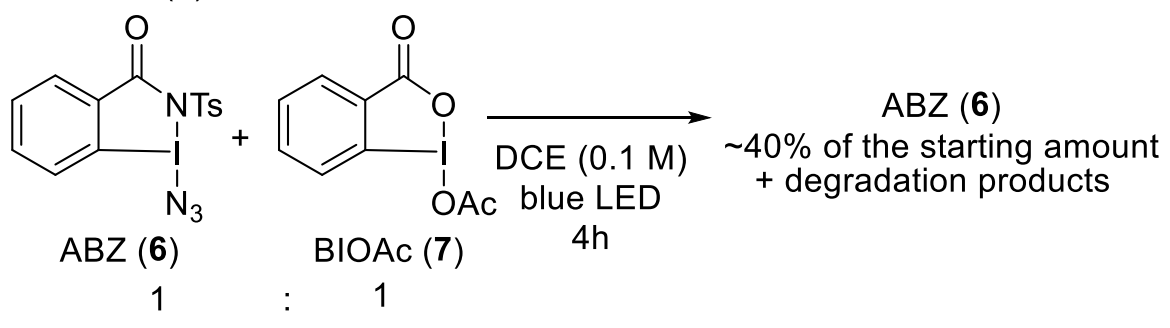

DCE was degassed by bubbling Ar through it for $30 \mathrm{~min}$. A $5 \mathrm{~mL}$ test tube, equipped with a stirring bar was charged with corresponding reagents $(0.1 \mathrm{mmol}) .1 \mathrm{~mL}$ of DCE was added to the reaction mixture. The reaction mixture was stirred under blue LED irradiation for $4 \mathrm{~h}$. Then, the reaction mixture was concentrated under vacuum and analysed by ${ }^{1} \mathrm{H} \mathrm{NMR}$ using $\mathrm{CH}_{2} \mathrm{Br}_{2}$ as an internal standard. 


\section{NMR Spectra}

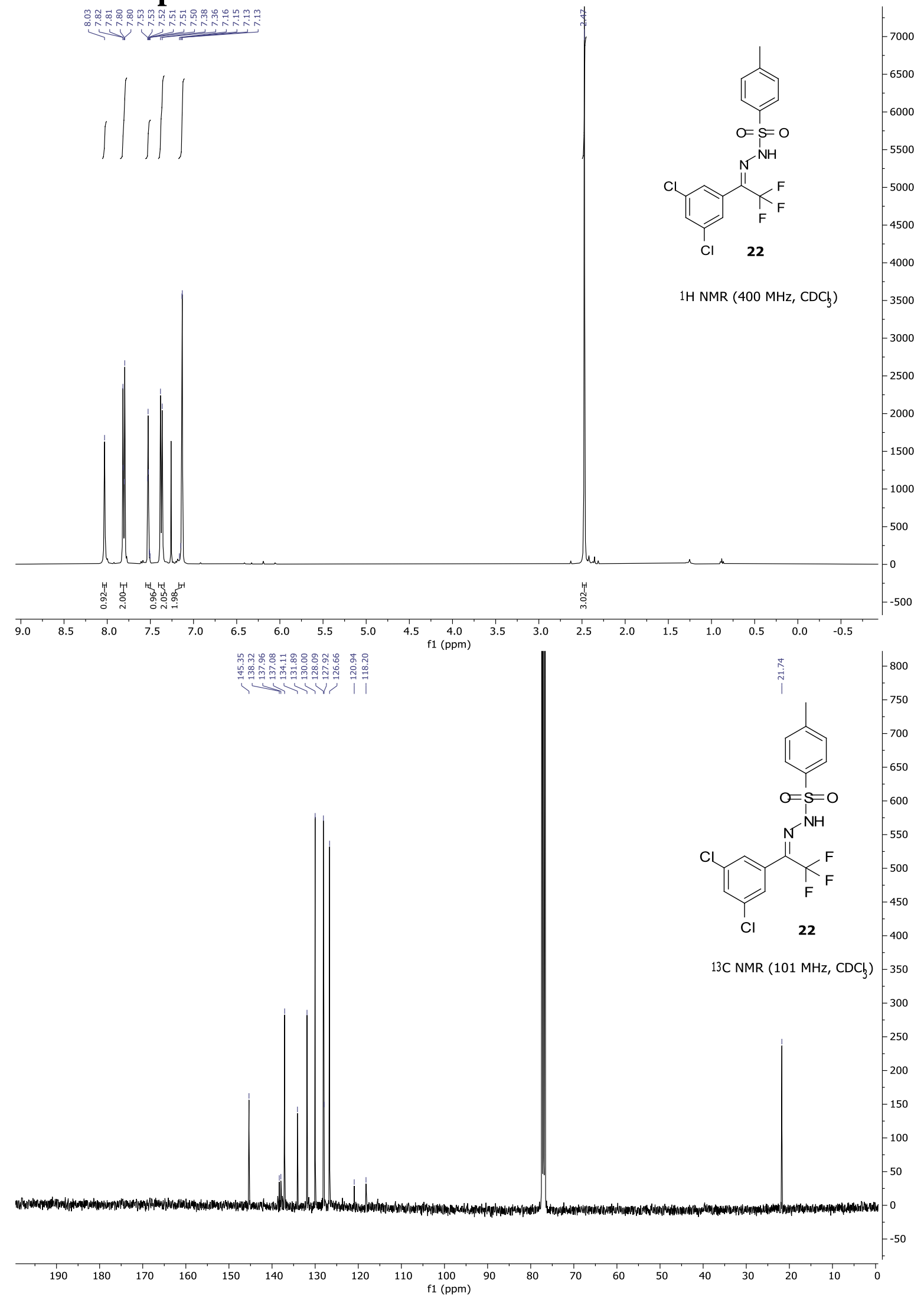




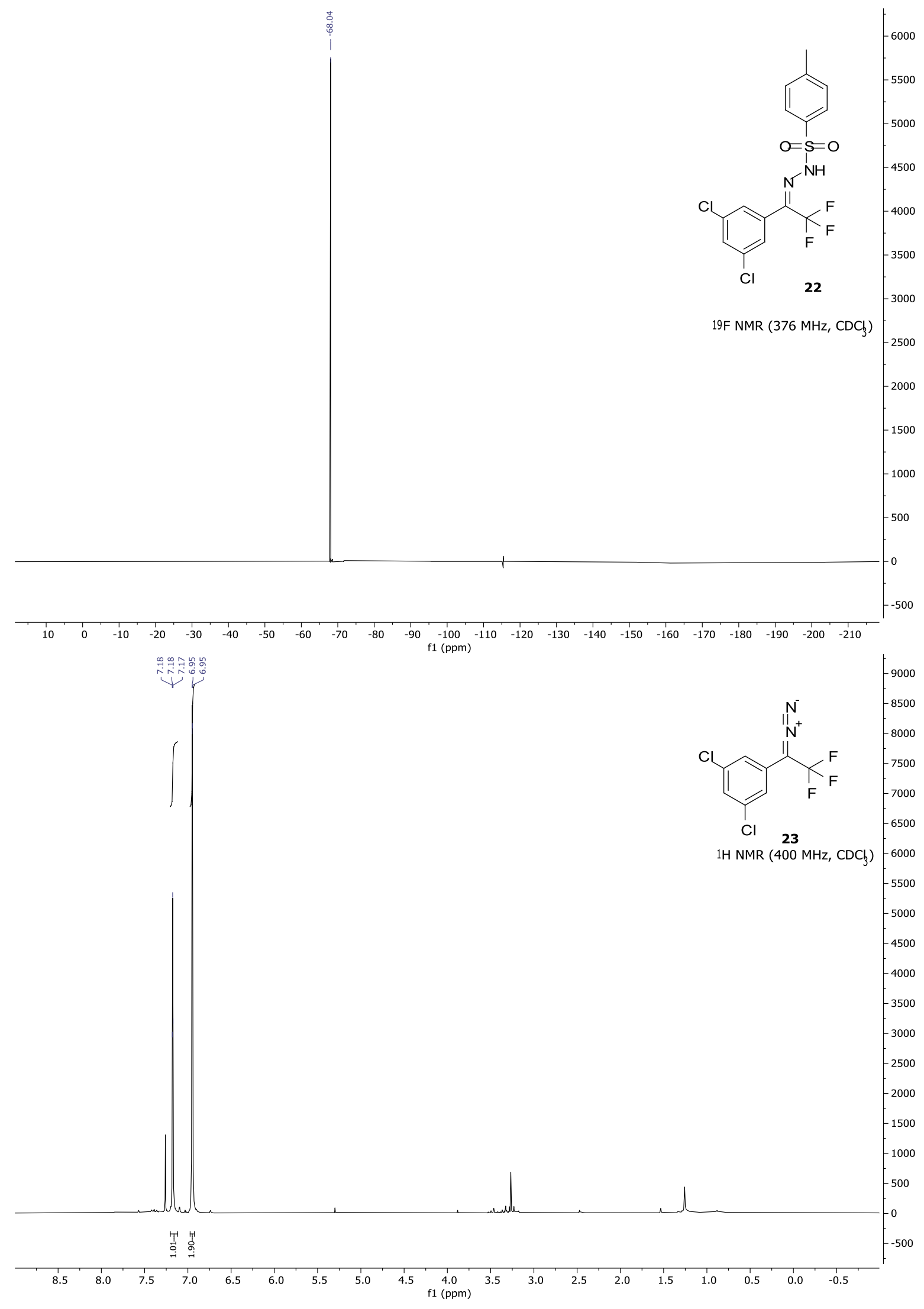




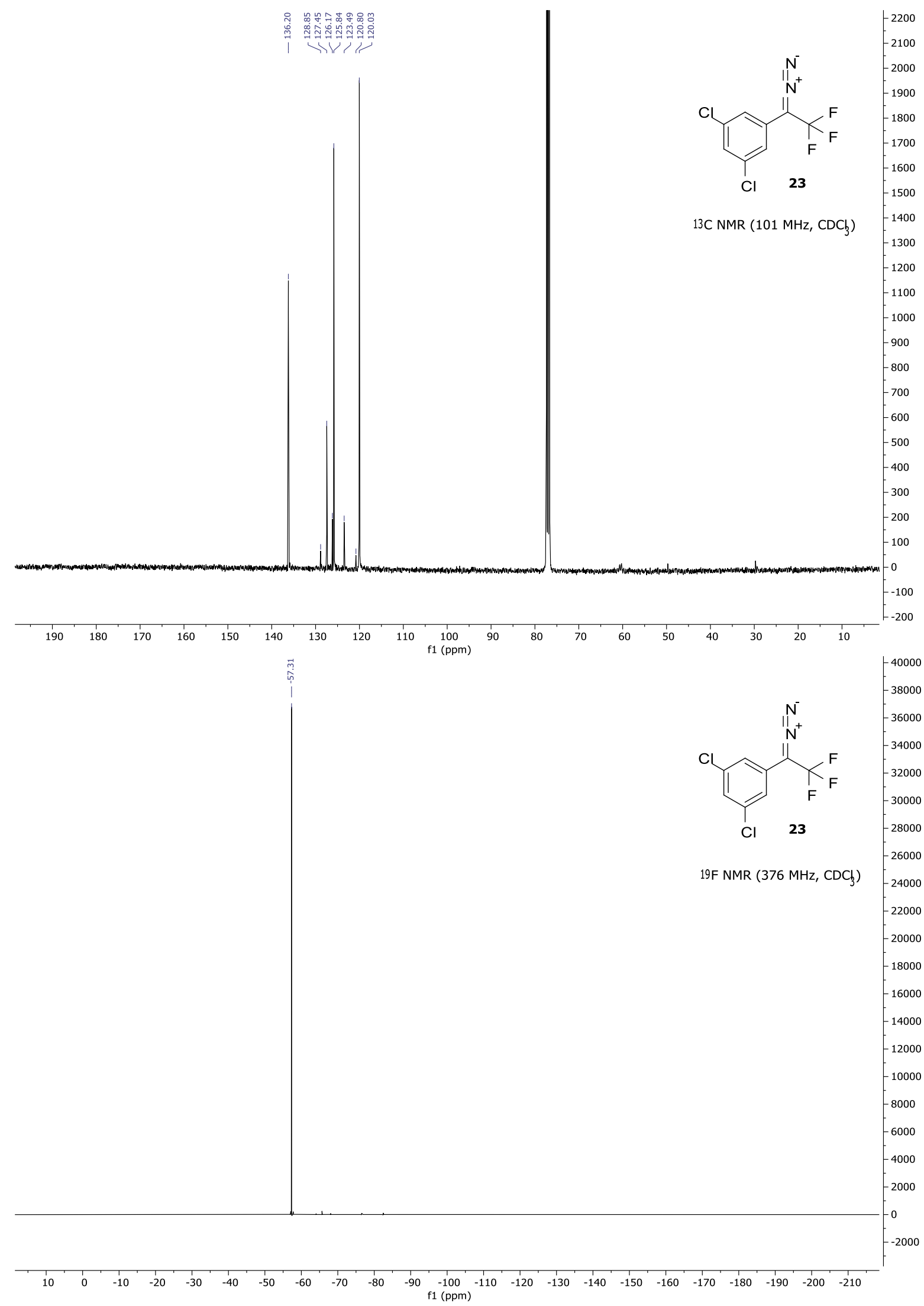




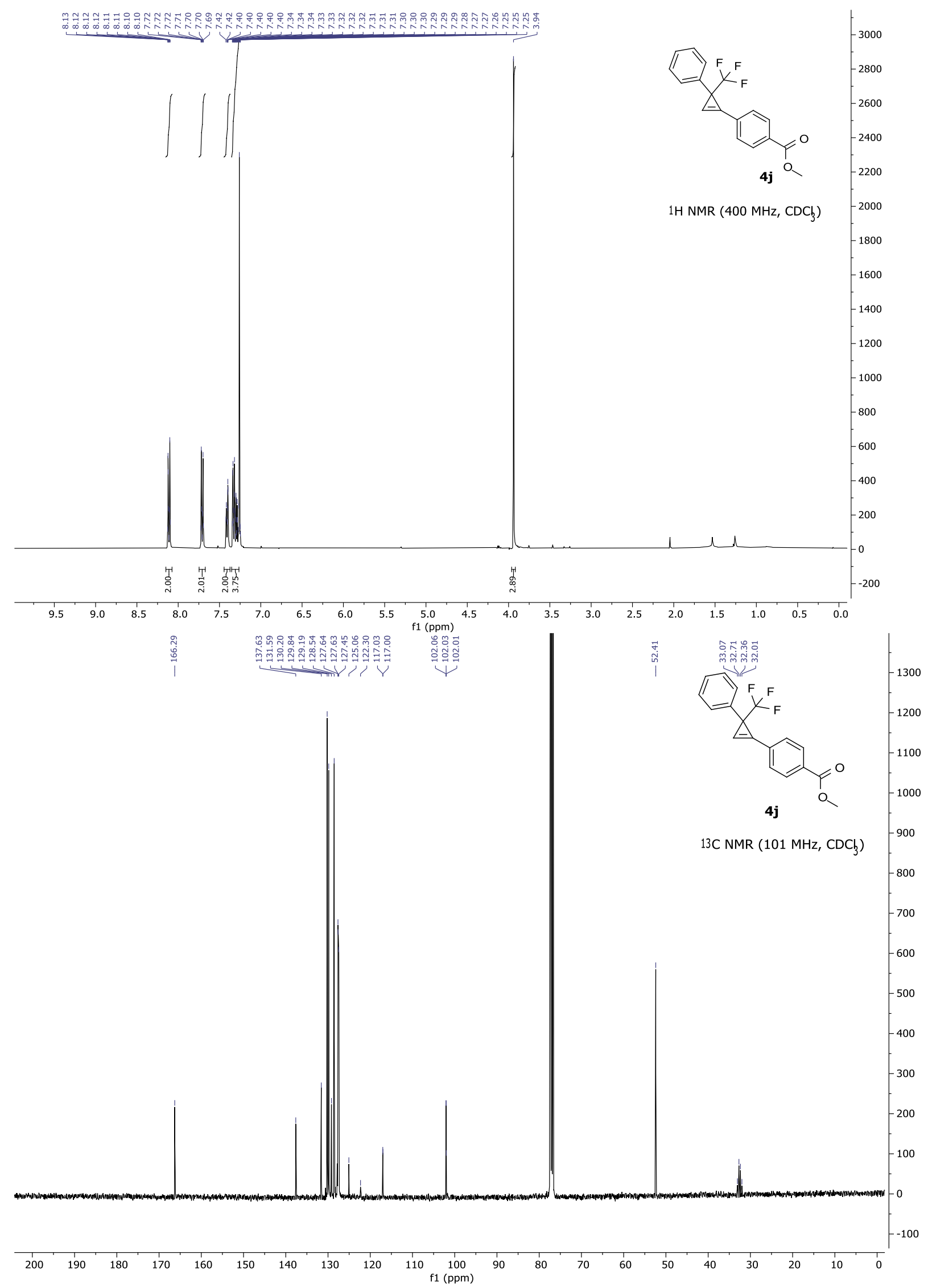




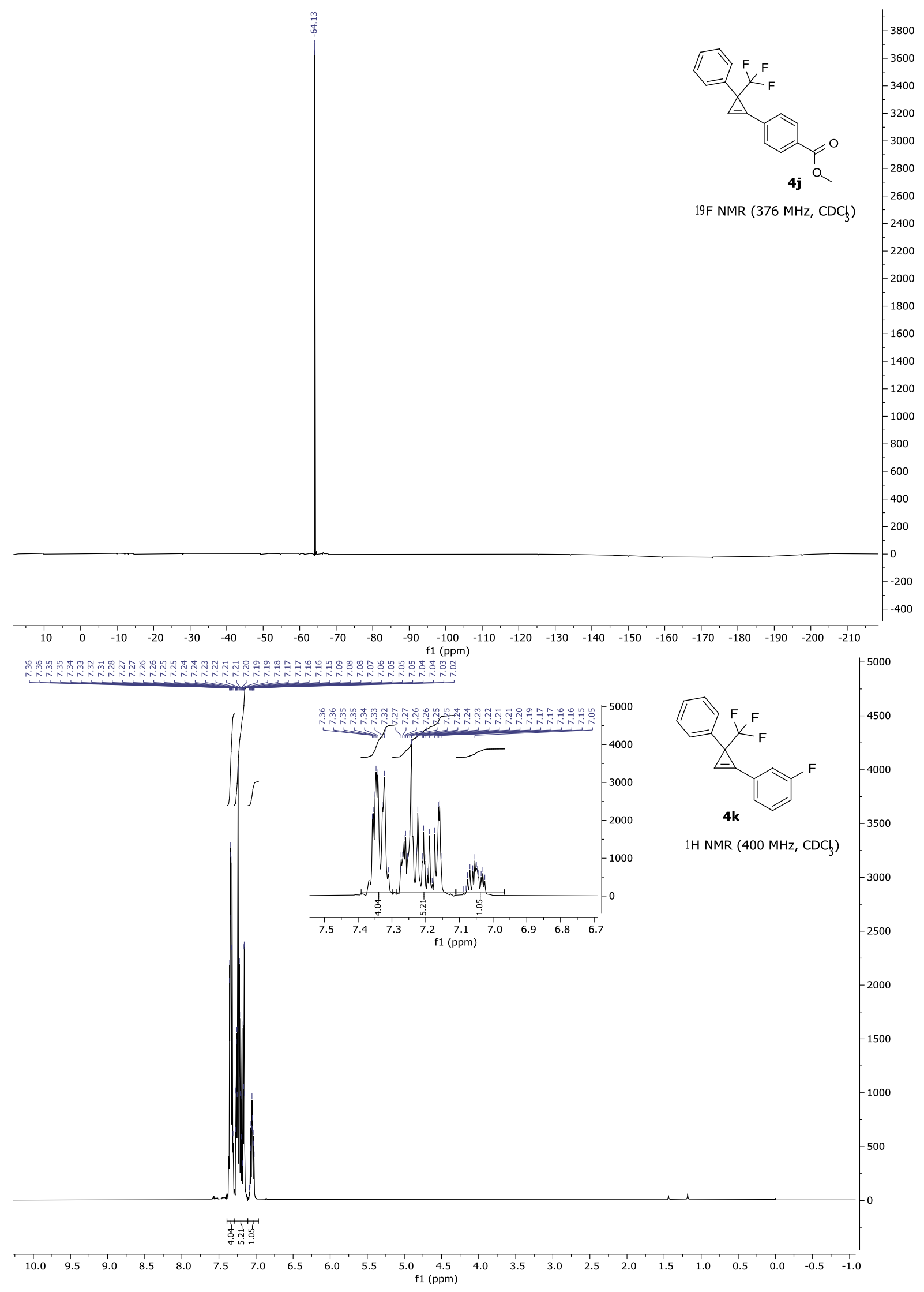



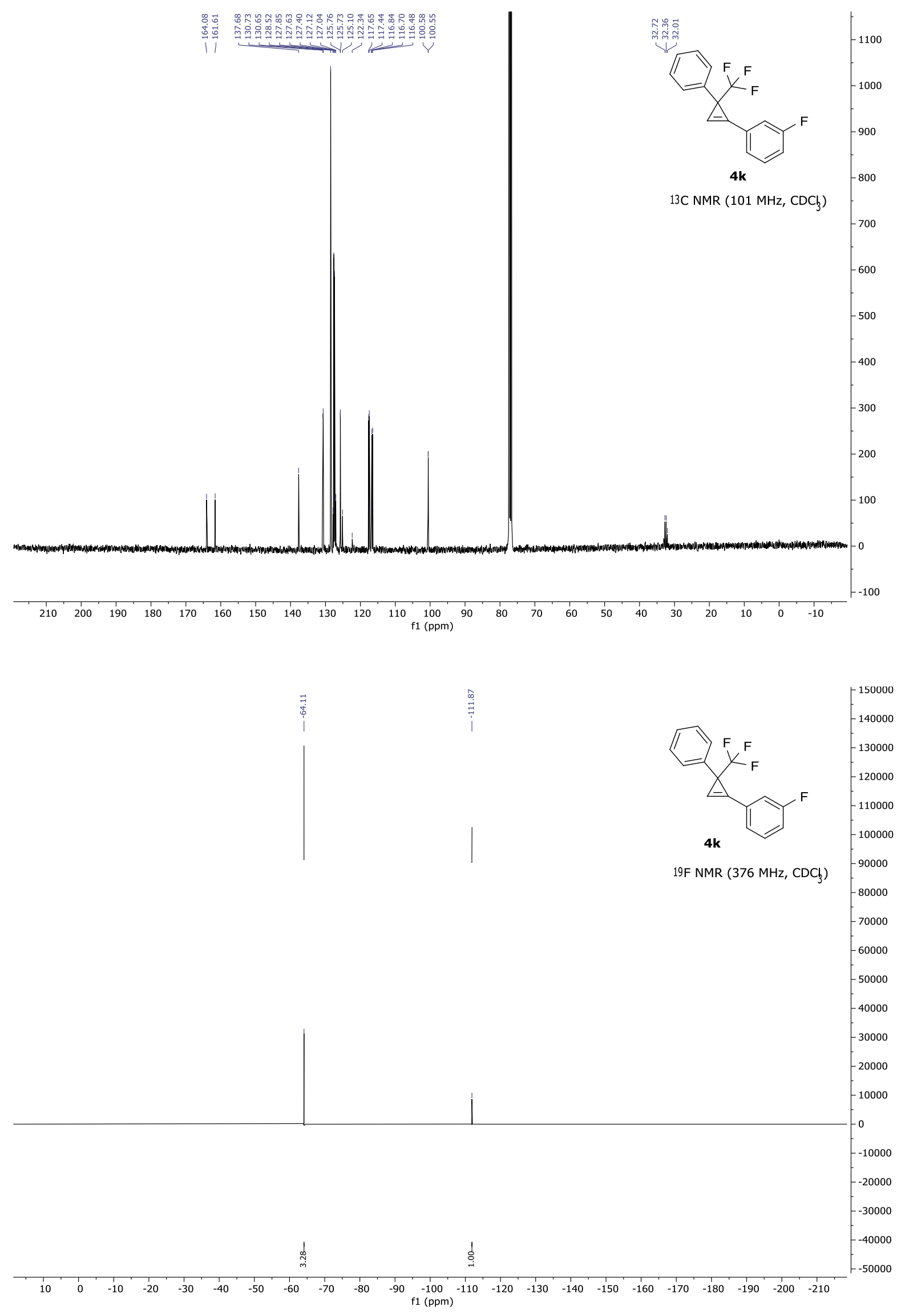


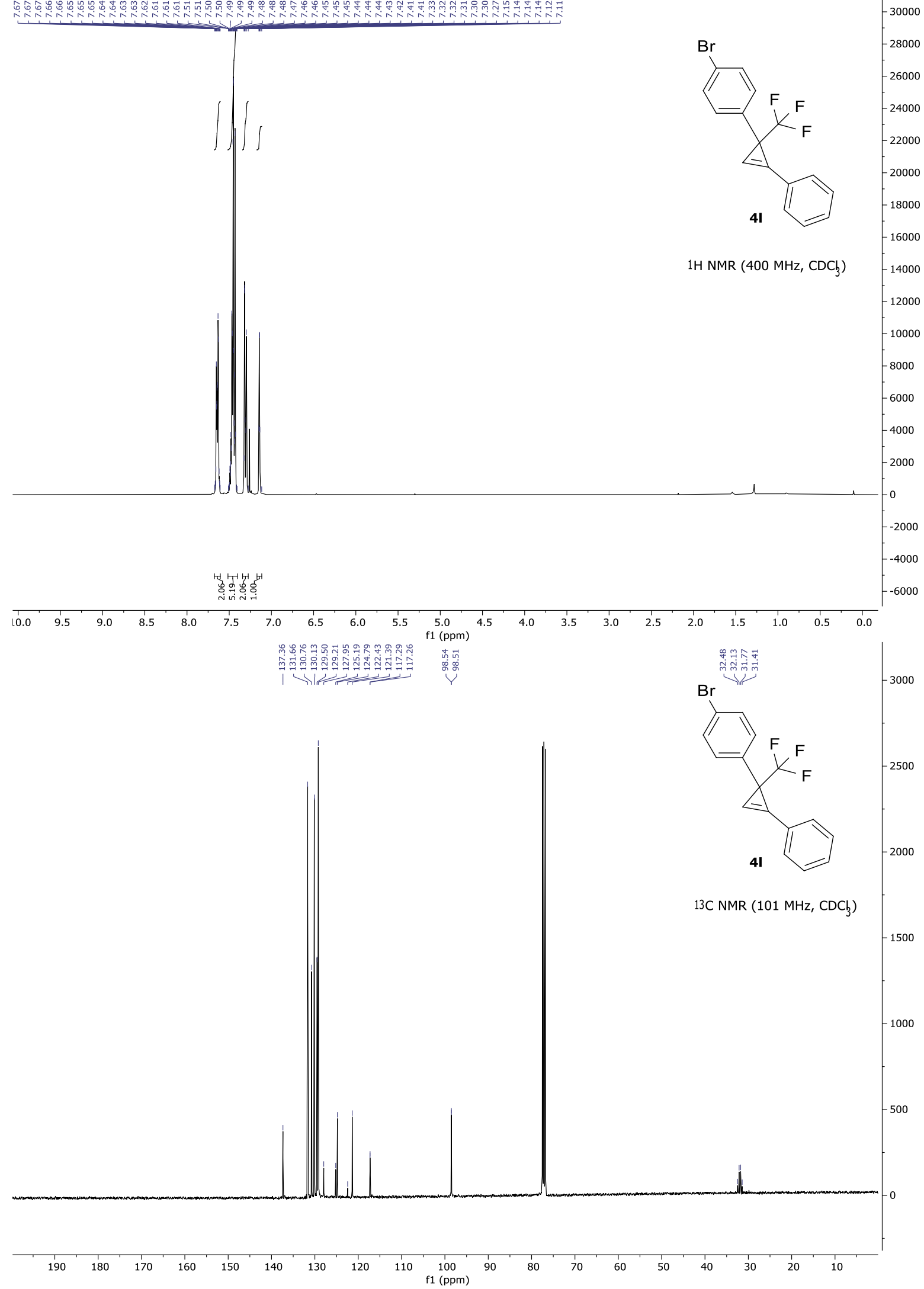




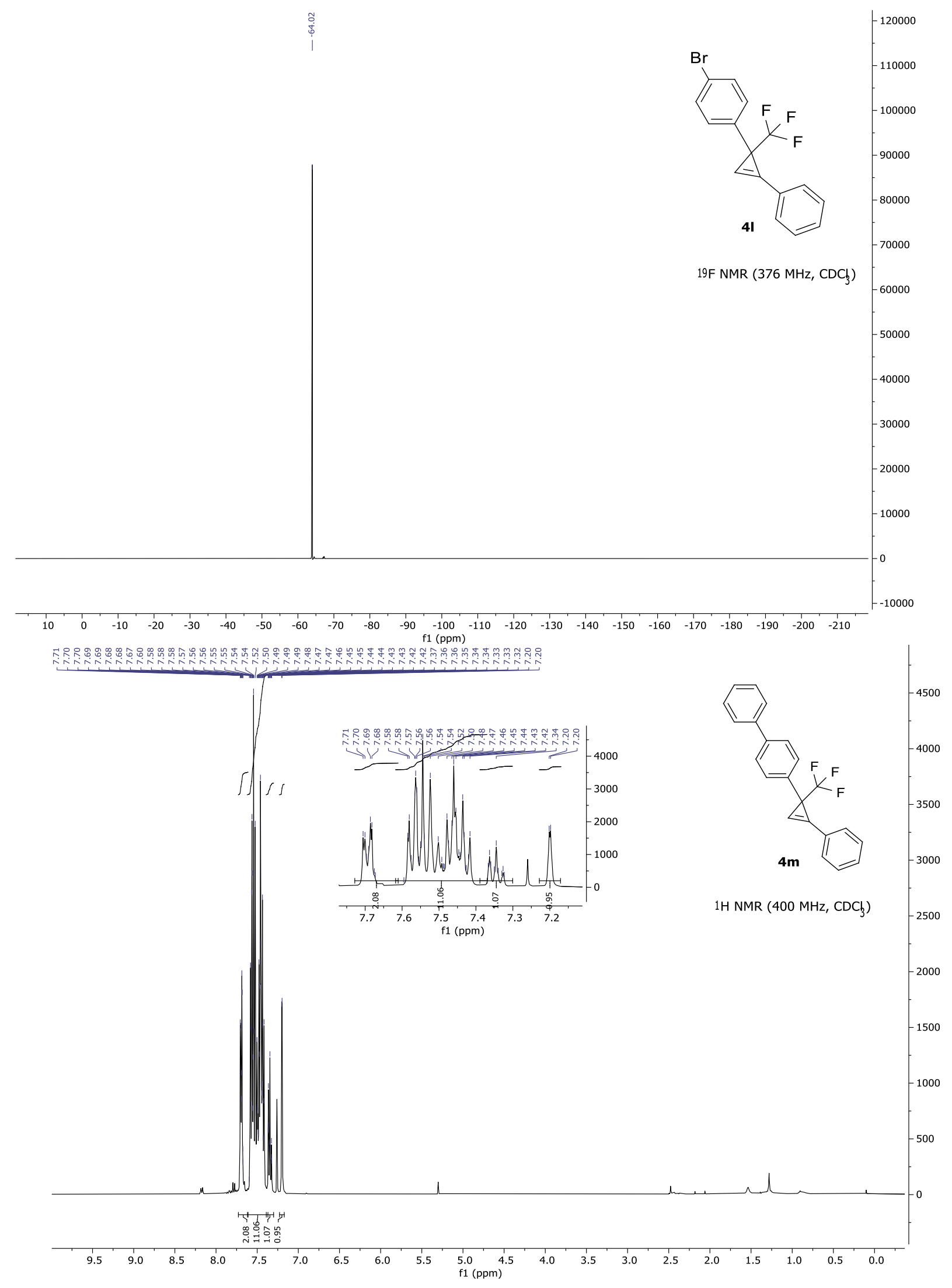



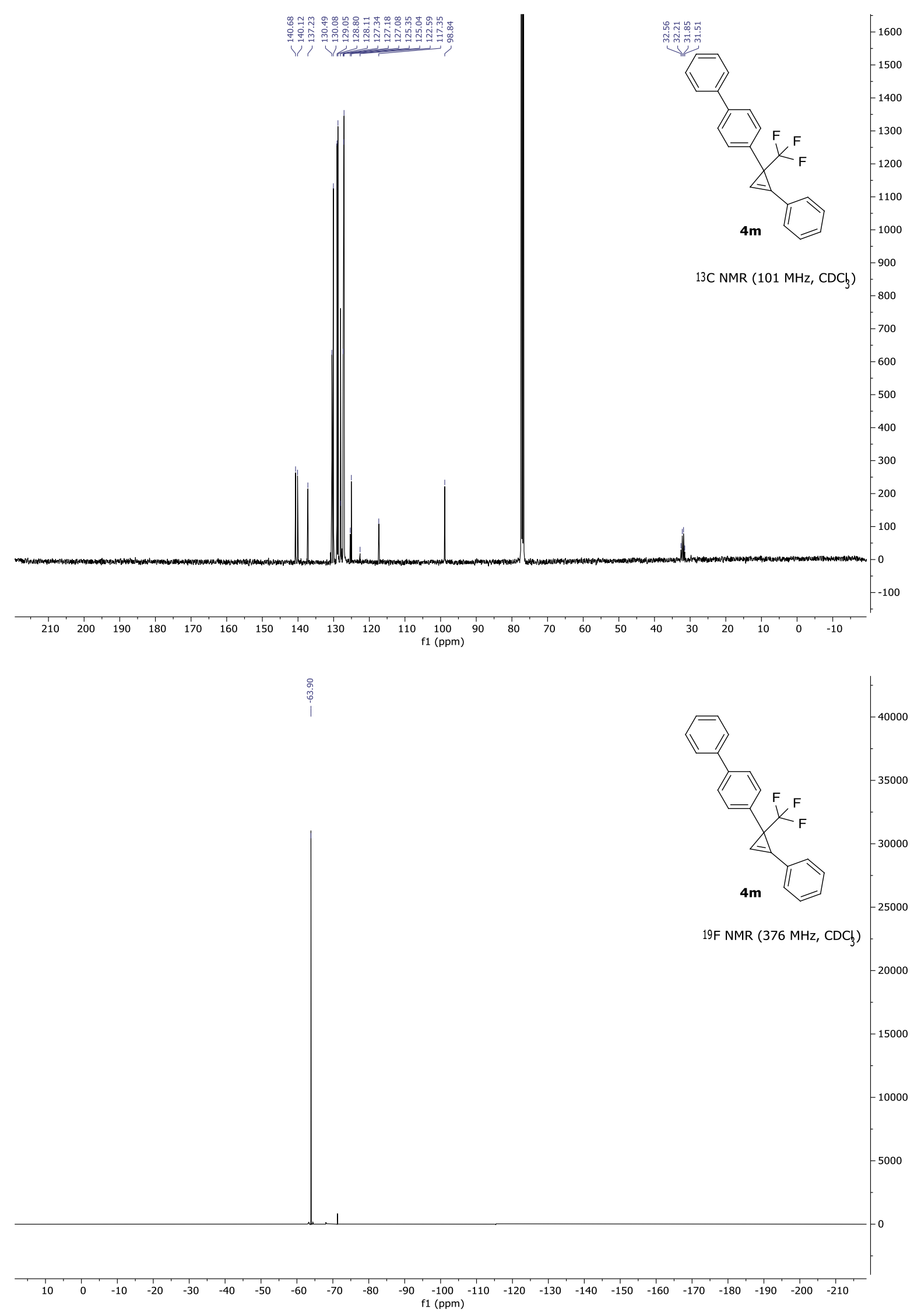


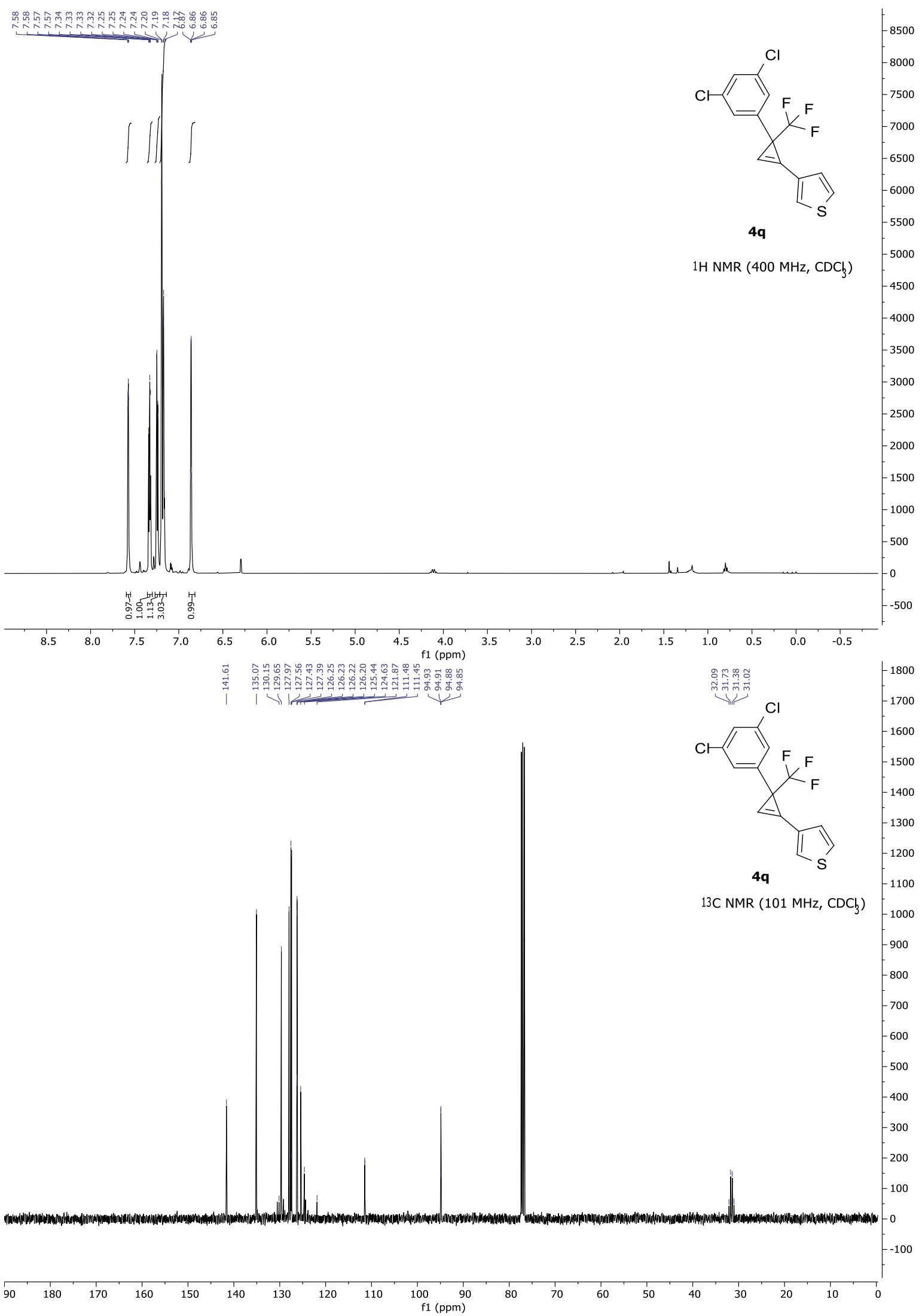




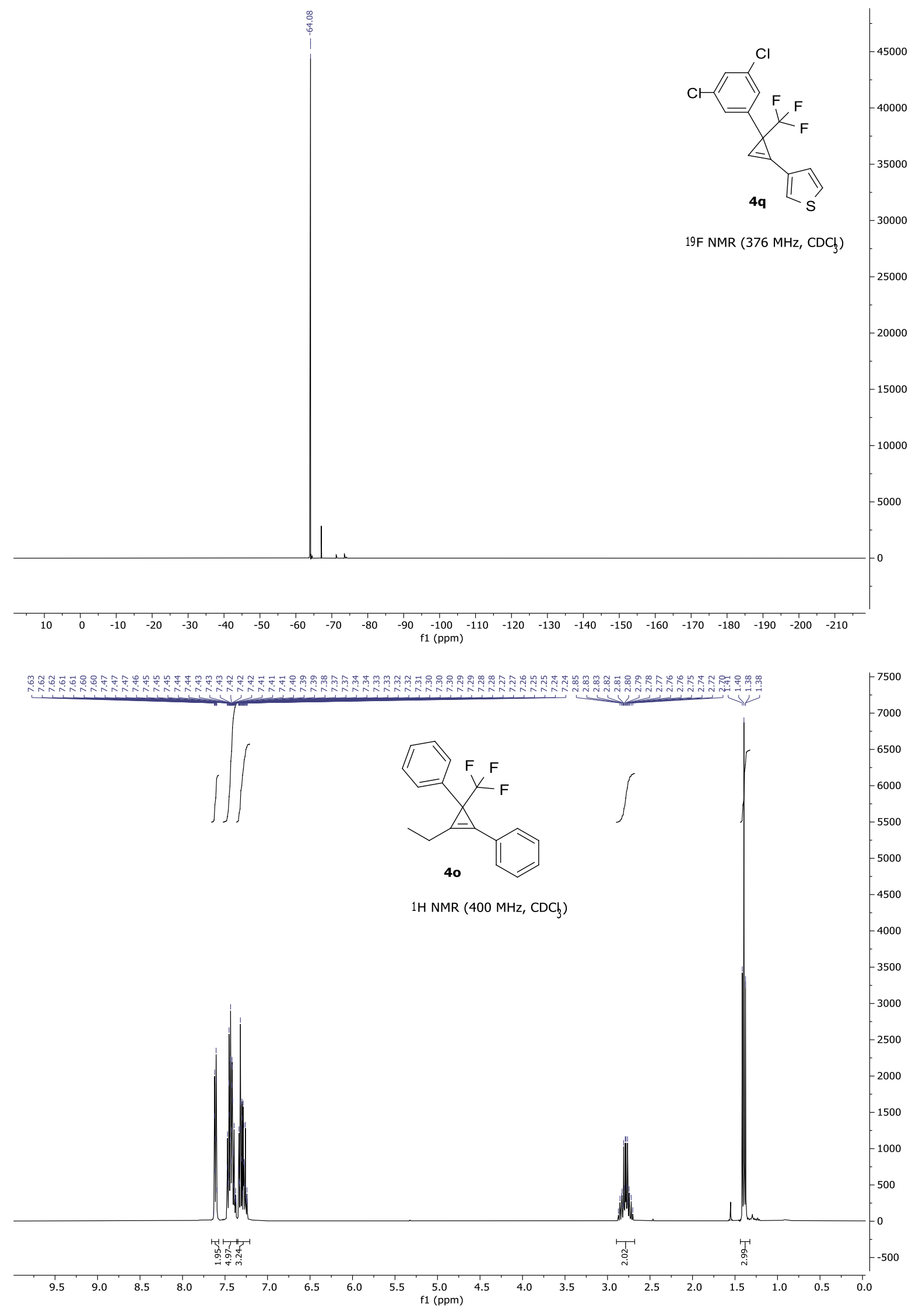




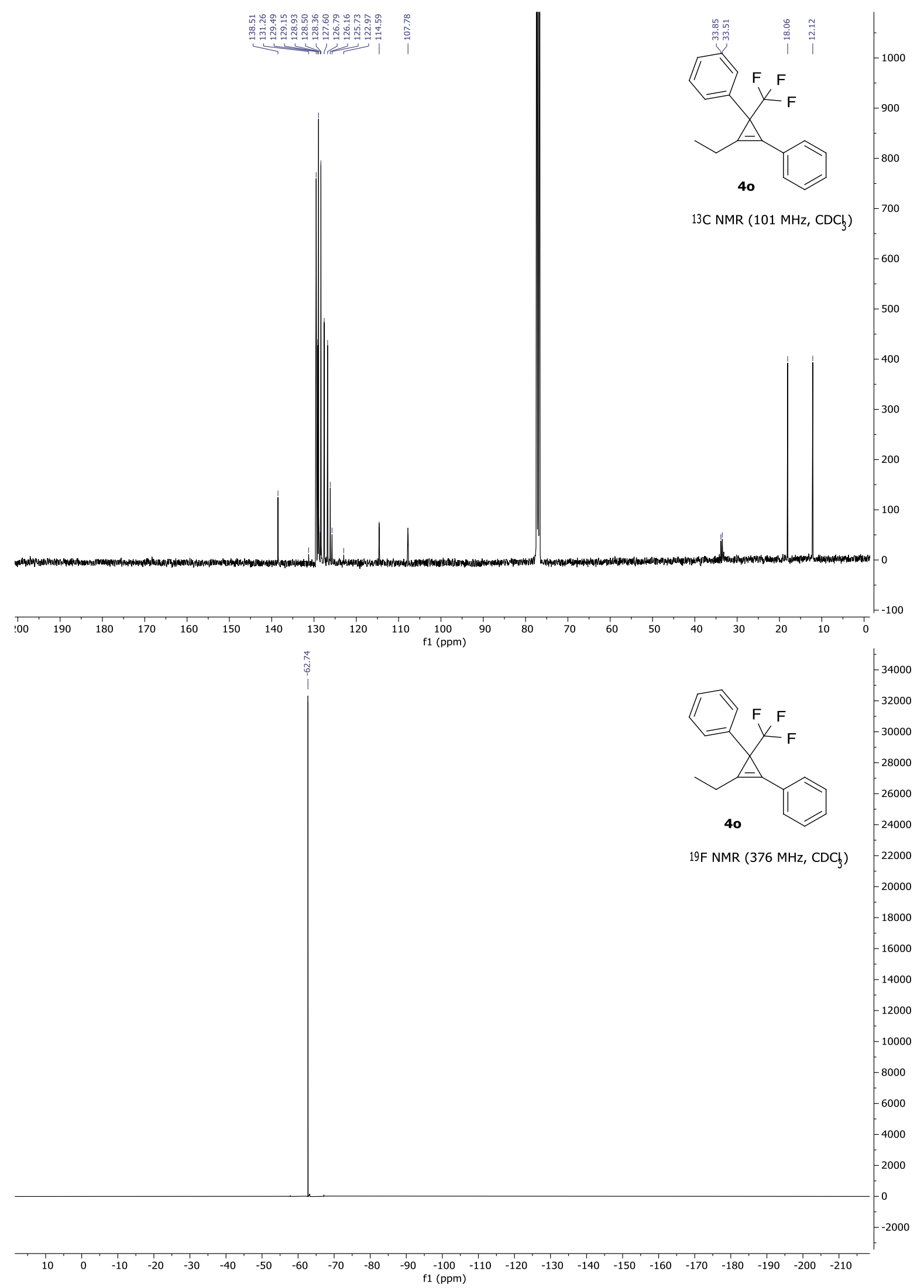




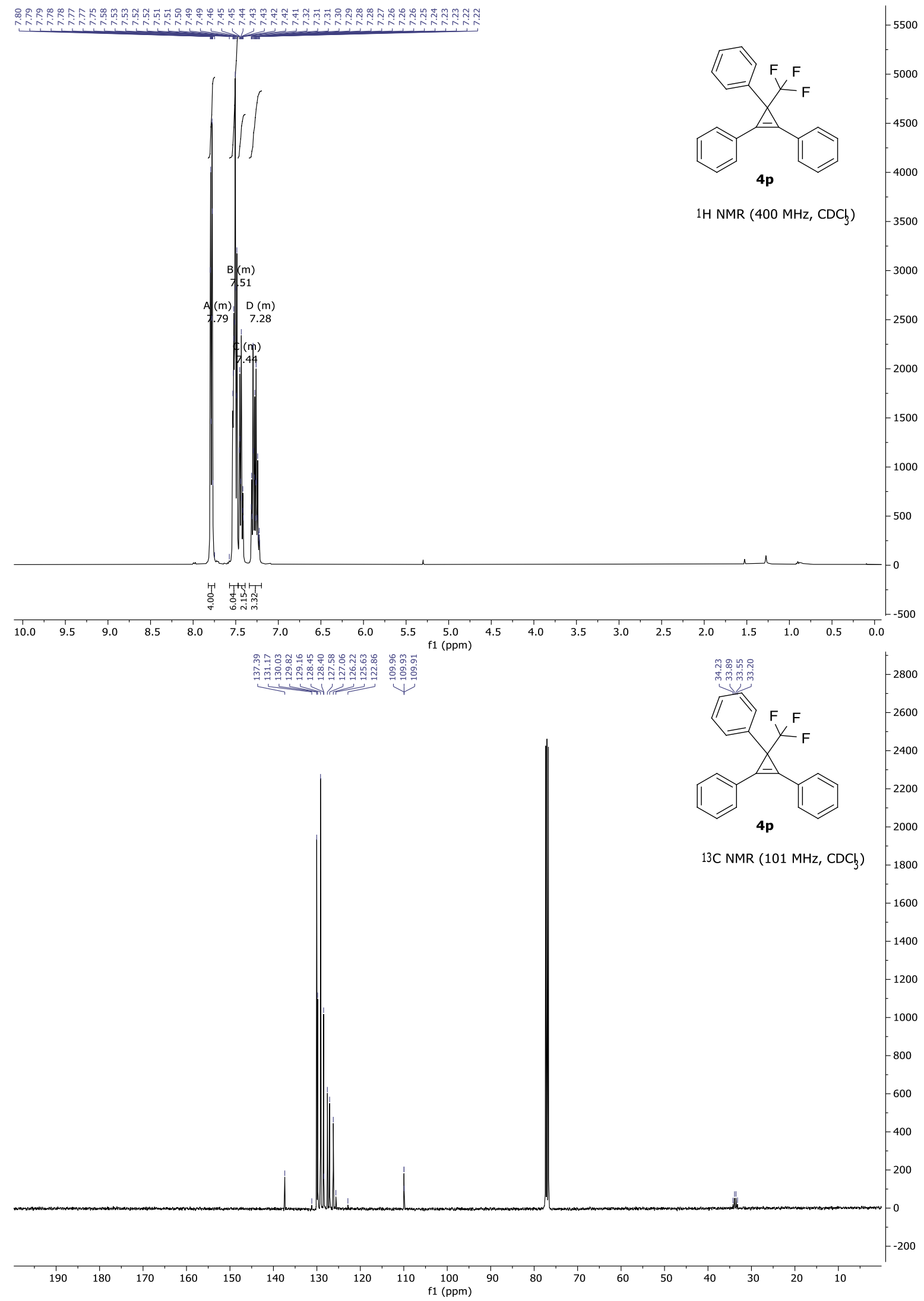




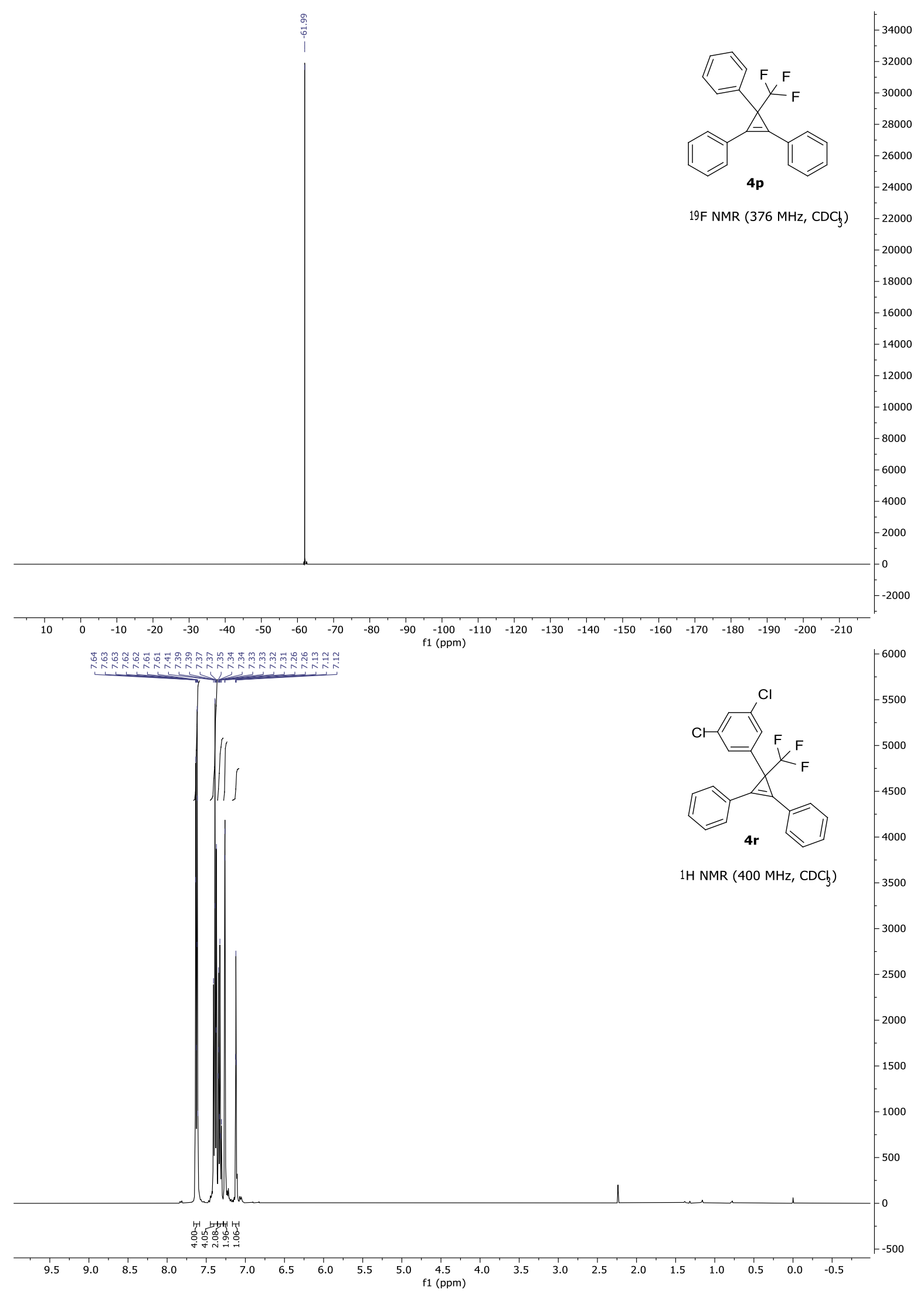




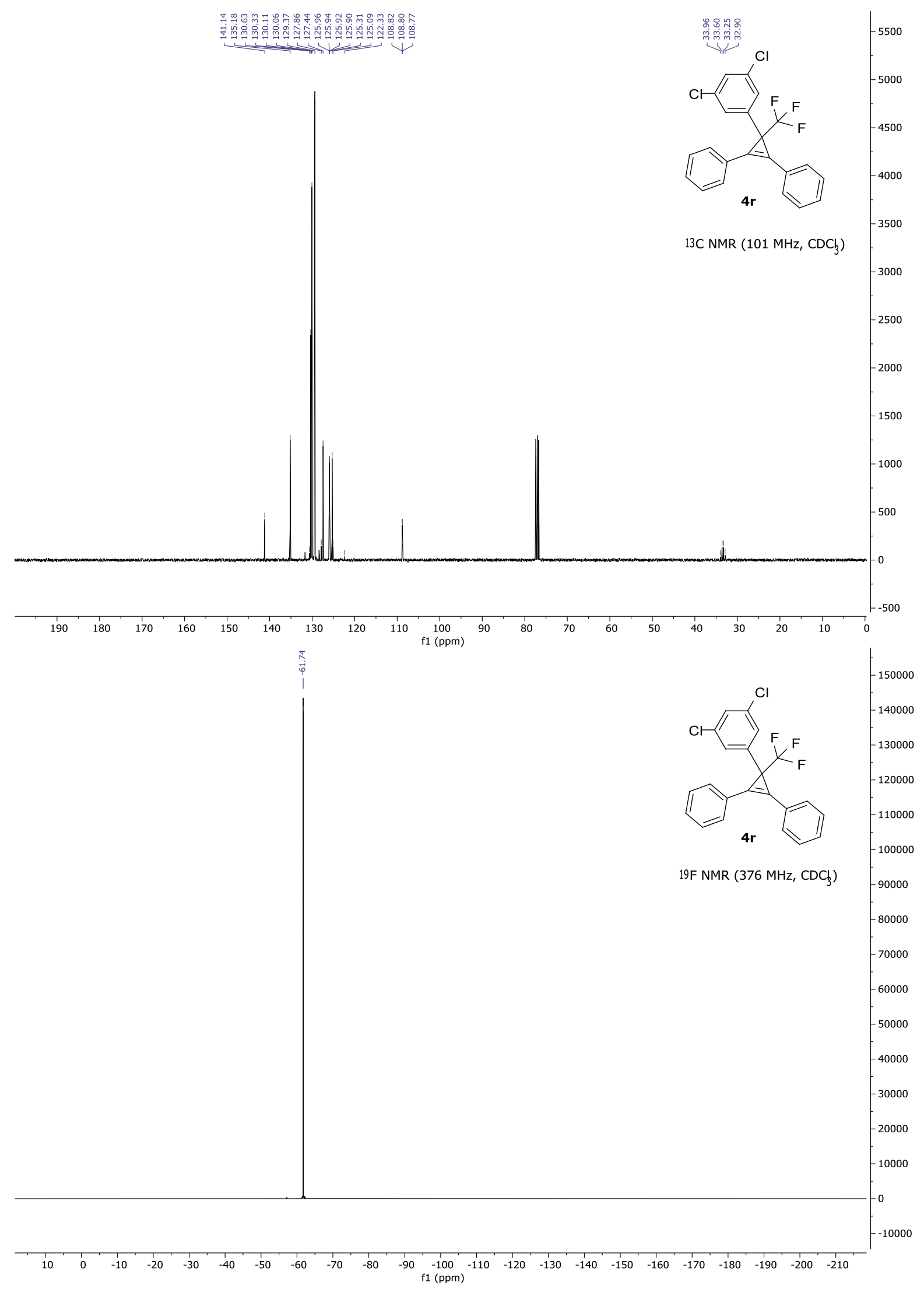




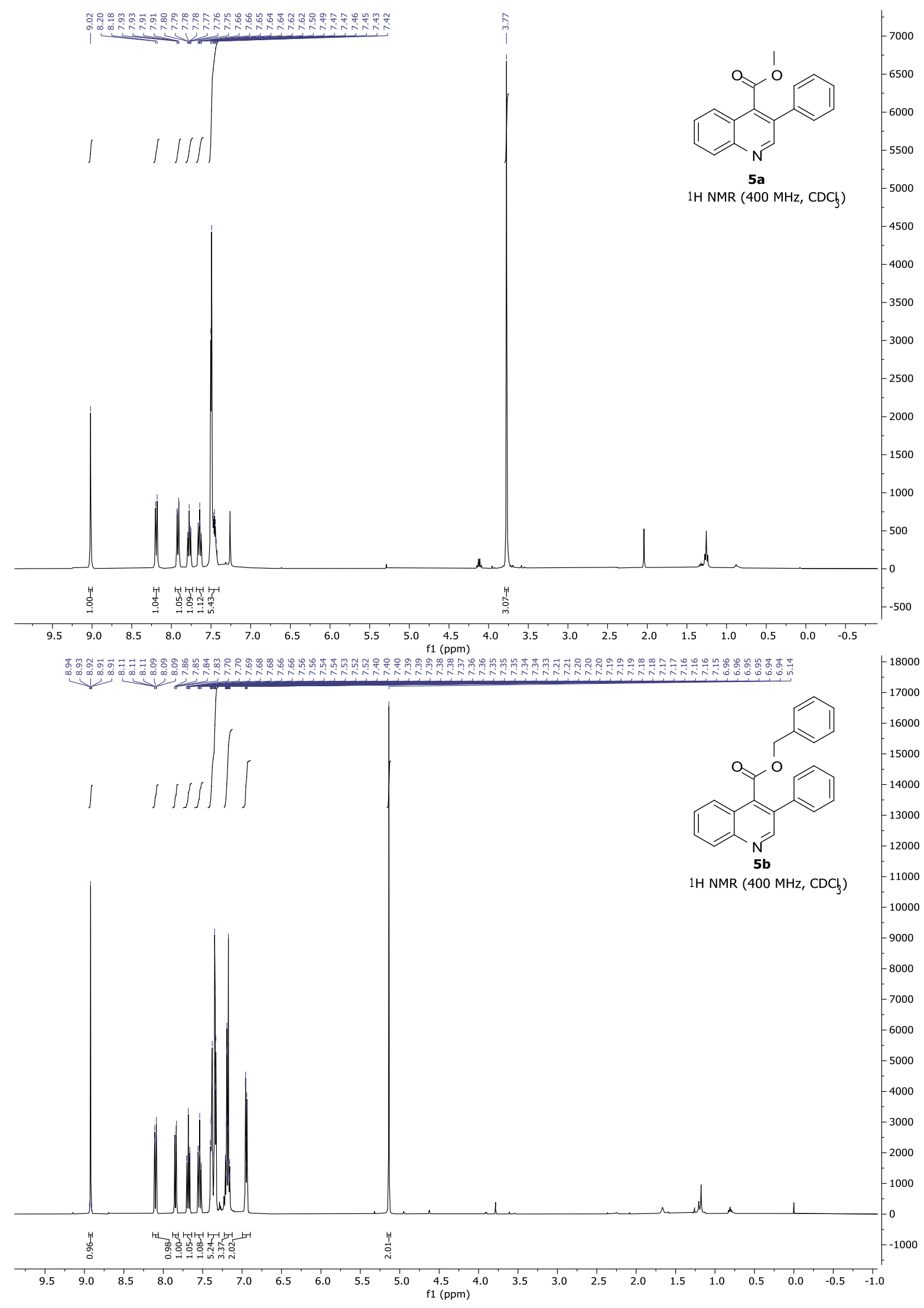




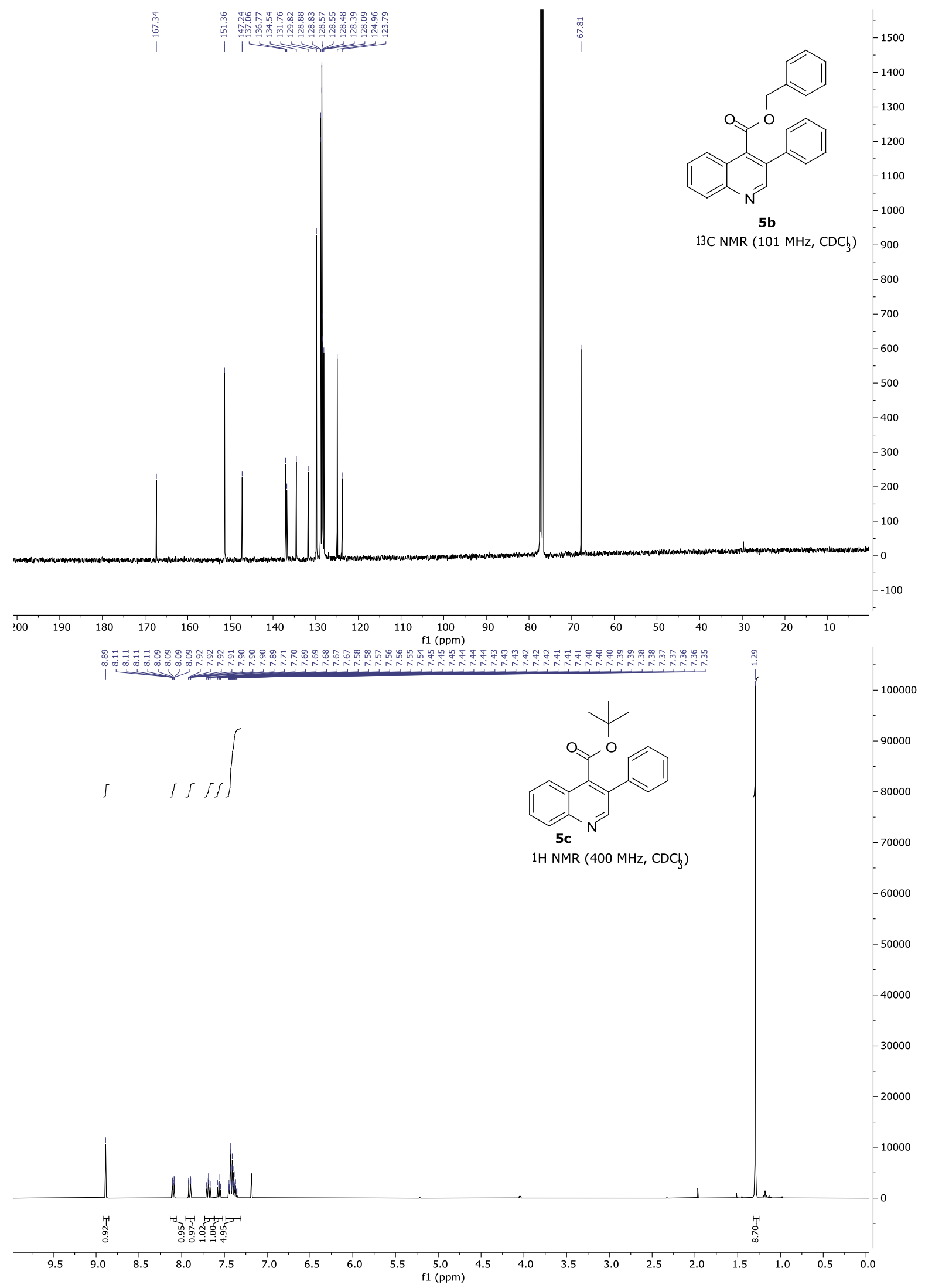




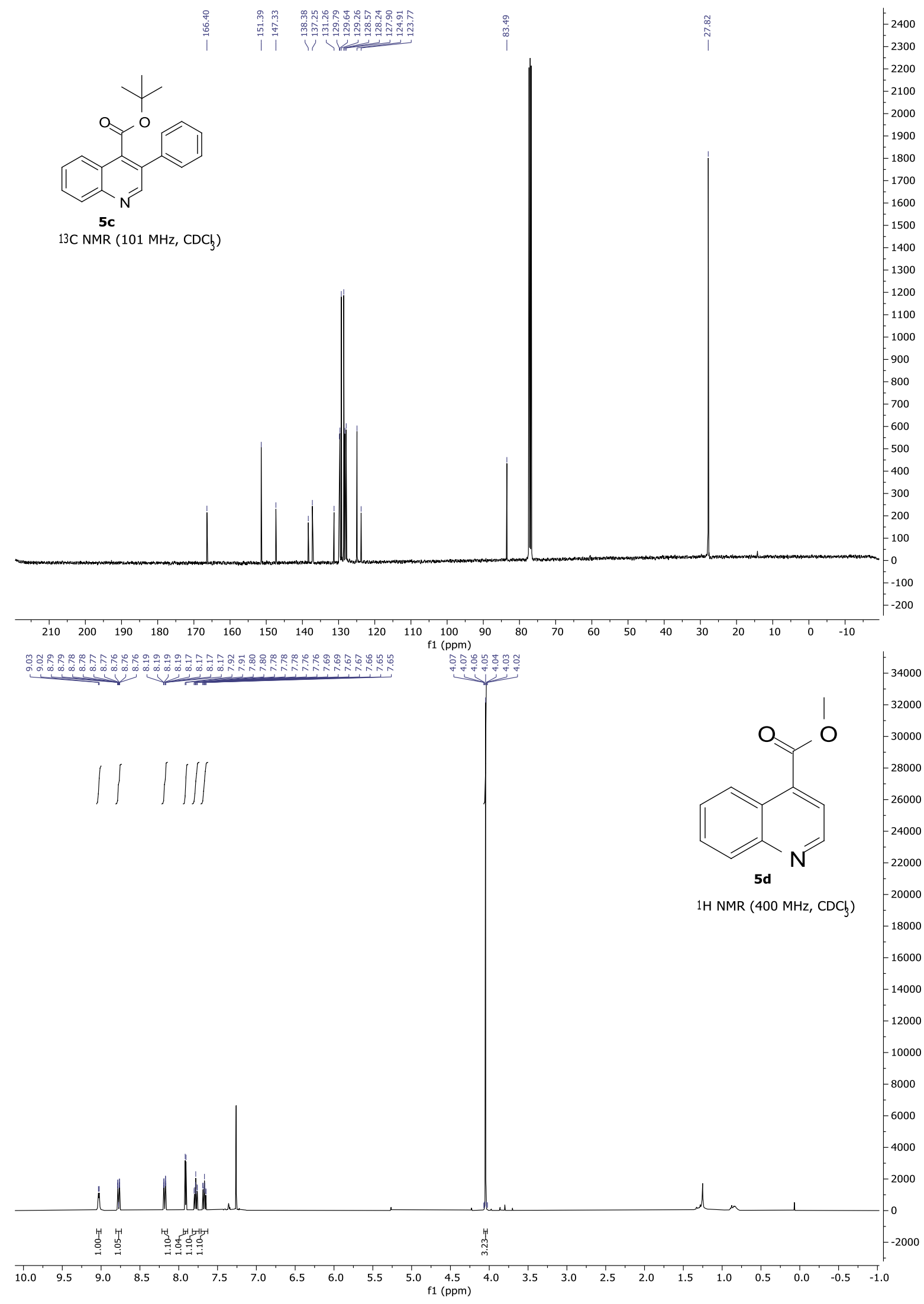




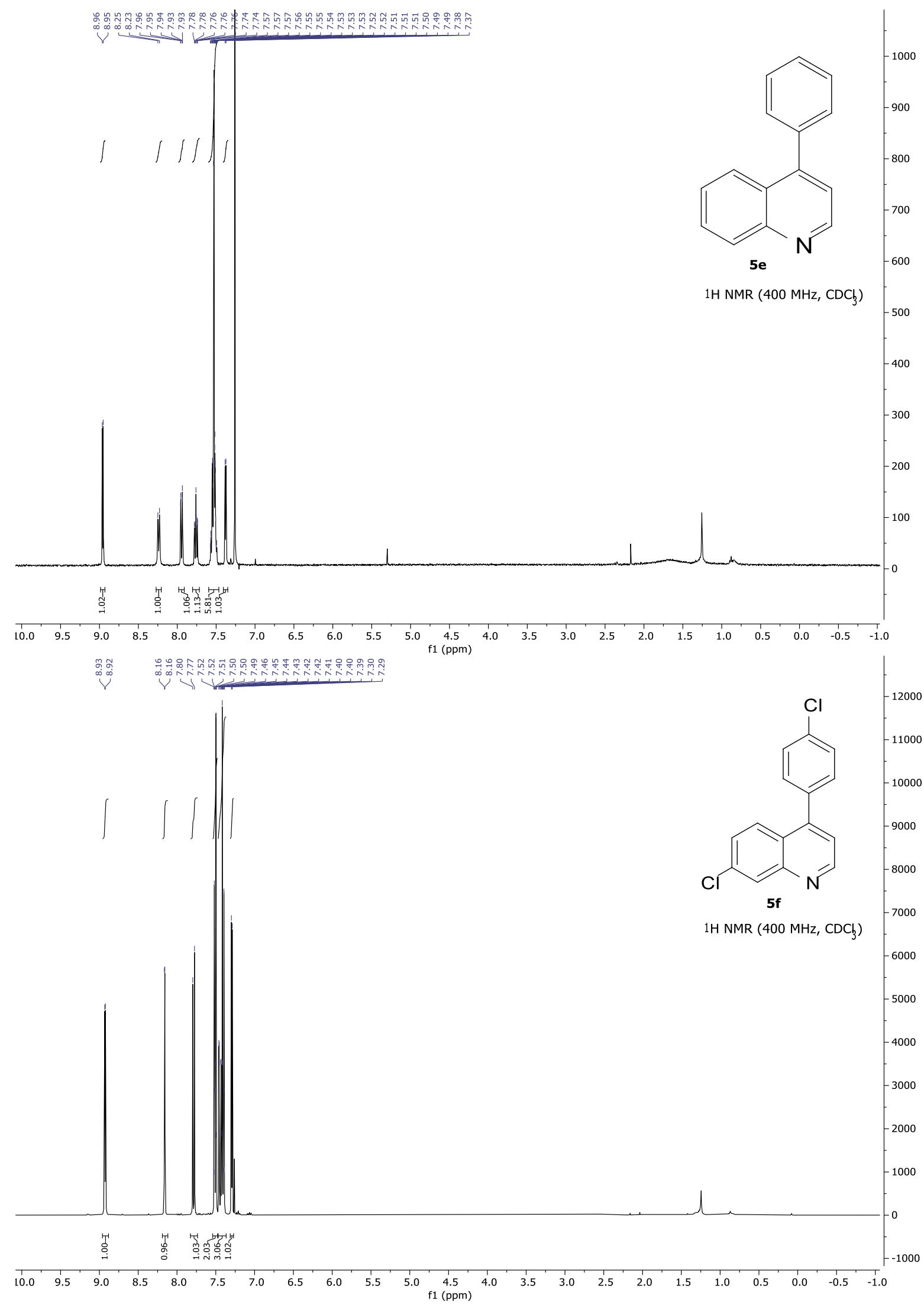




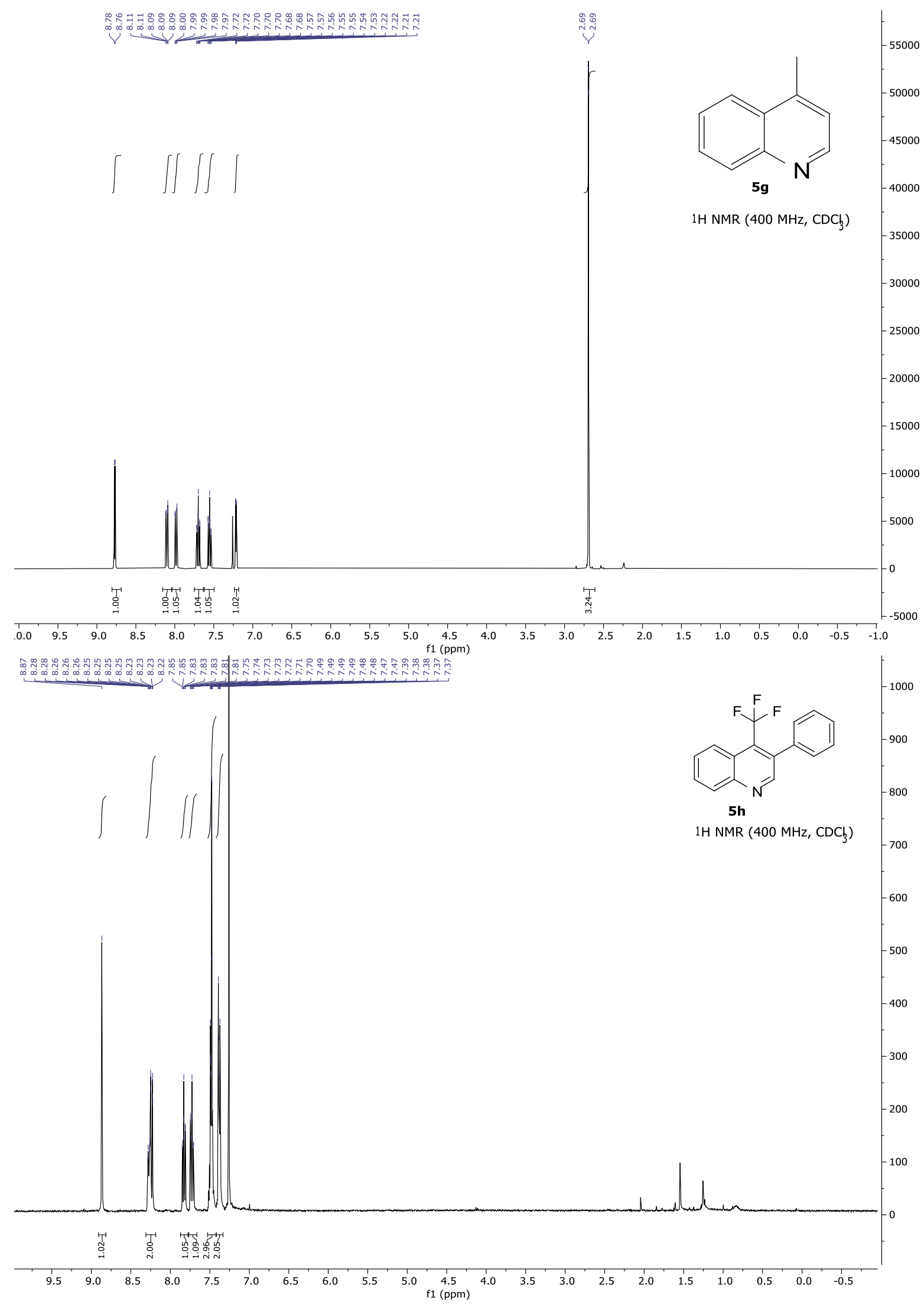




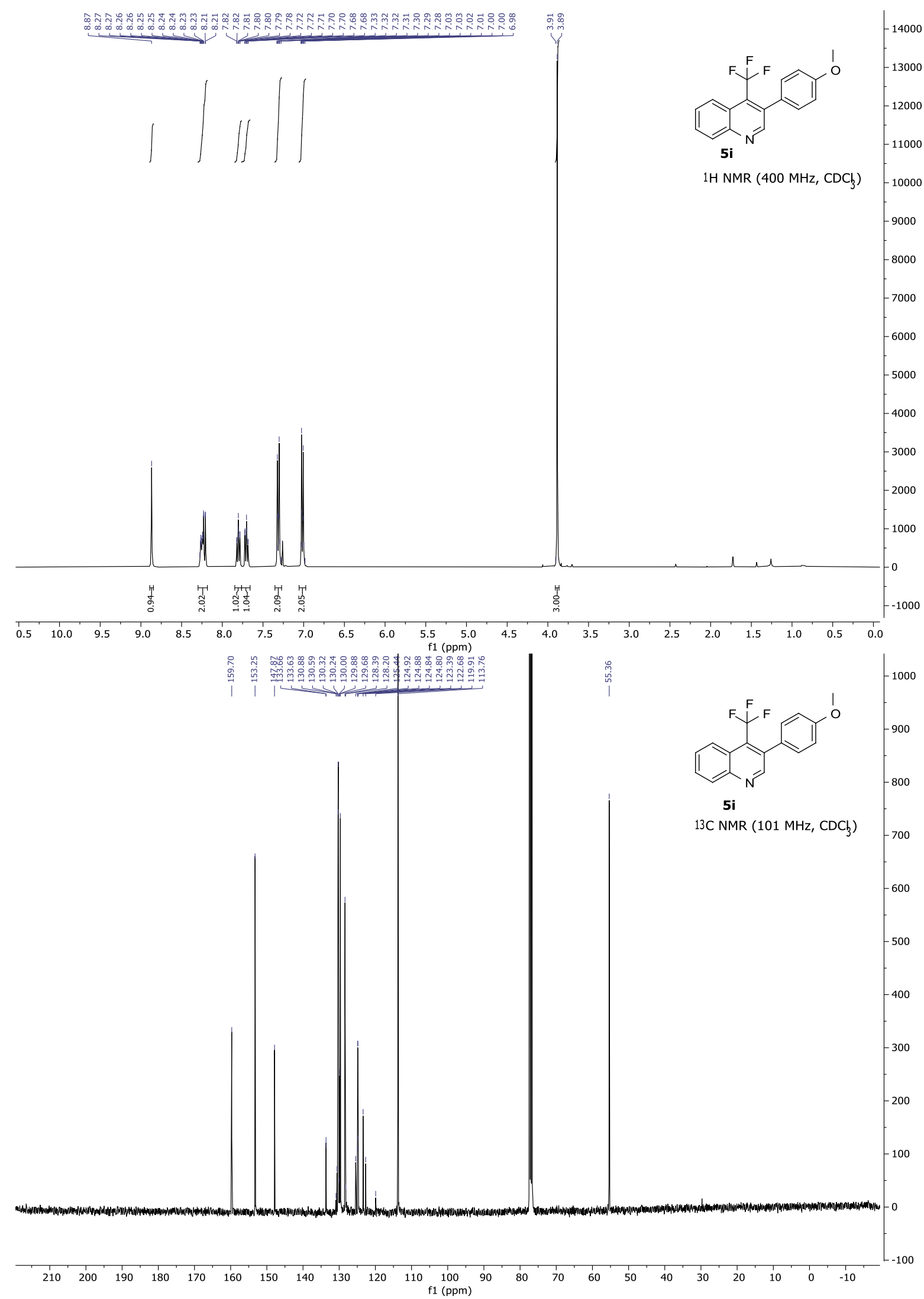




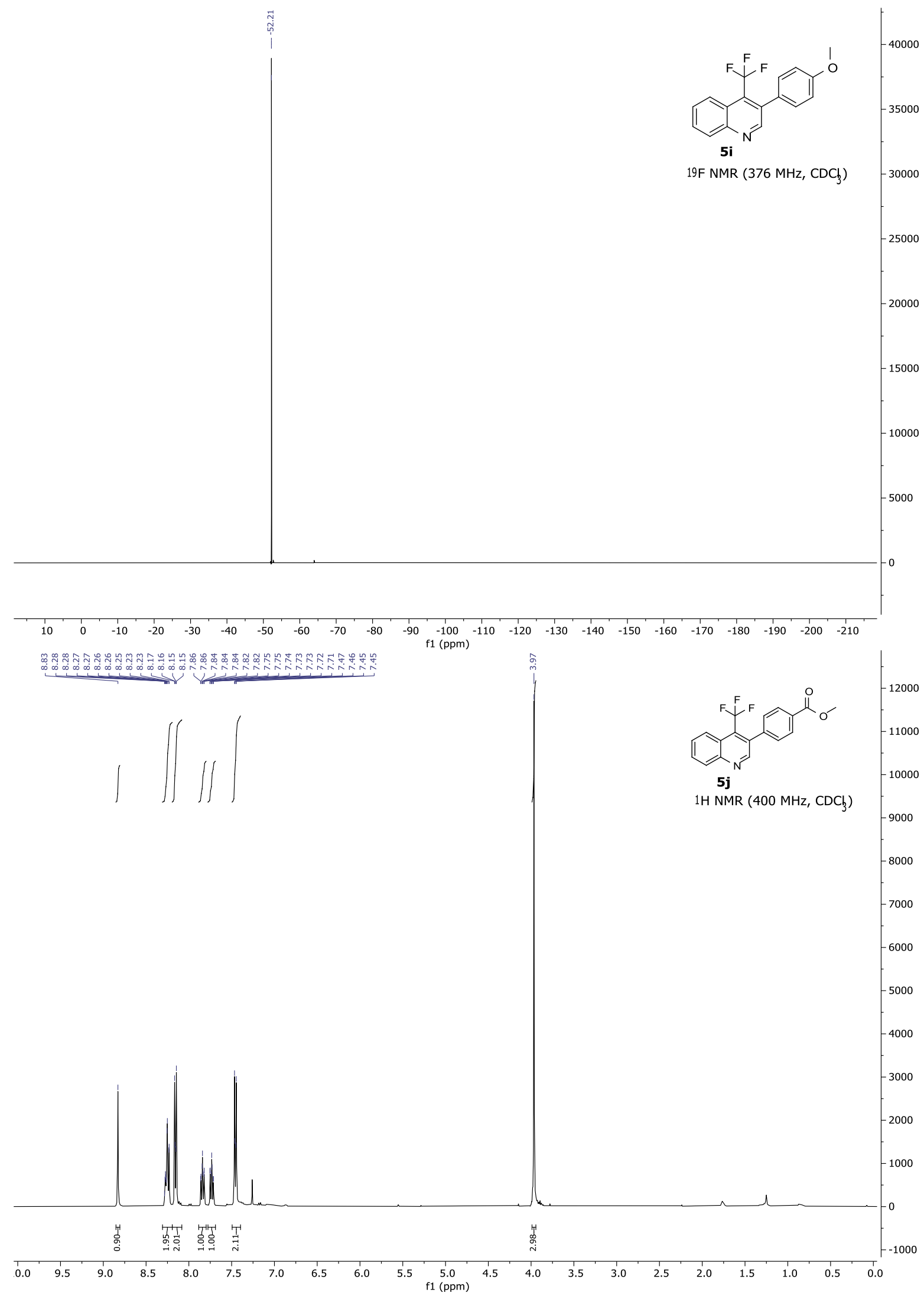




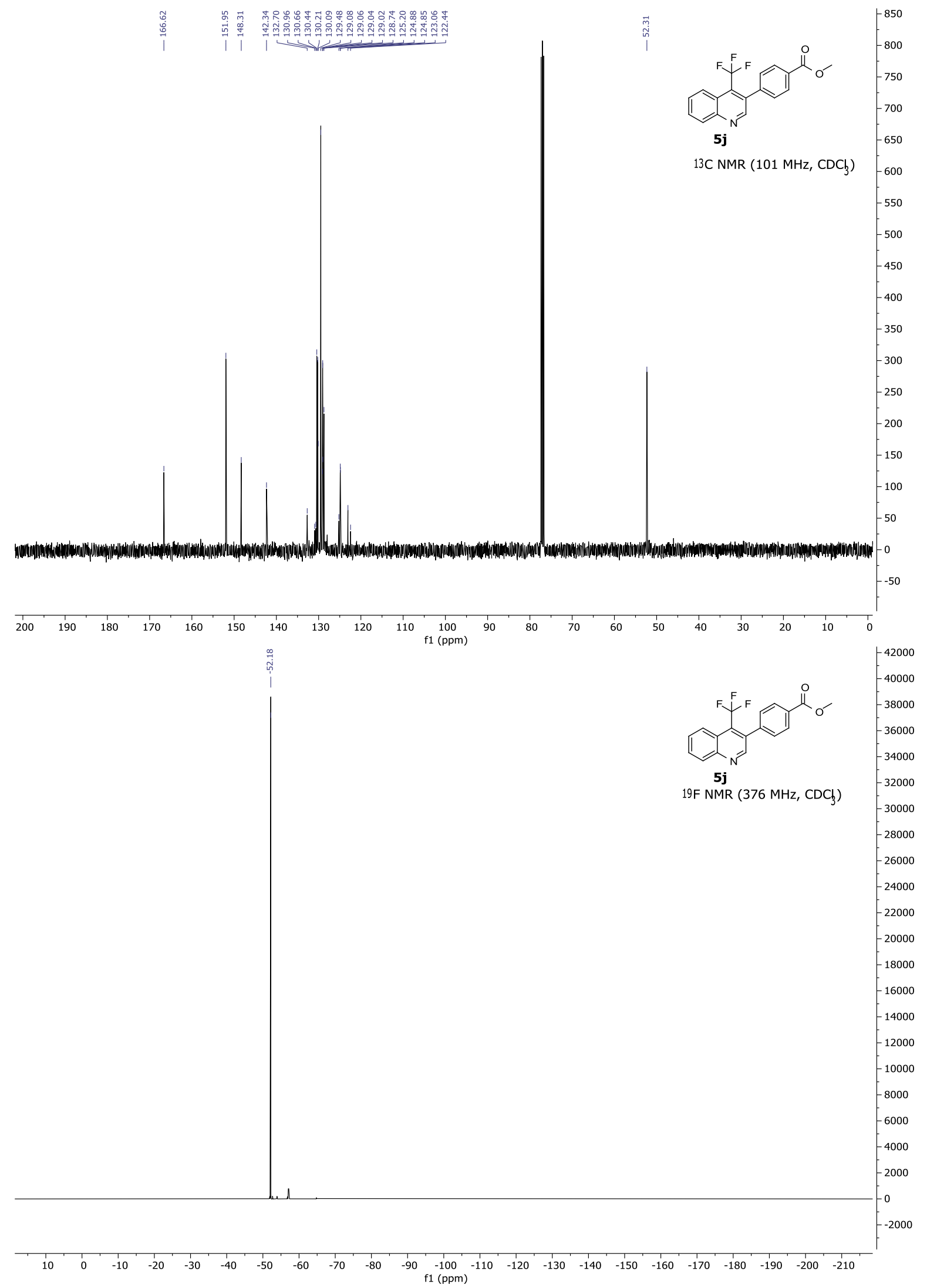




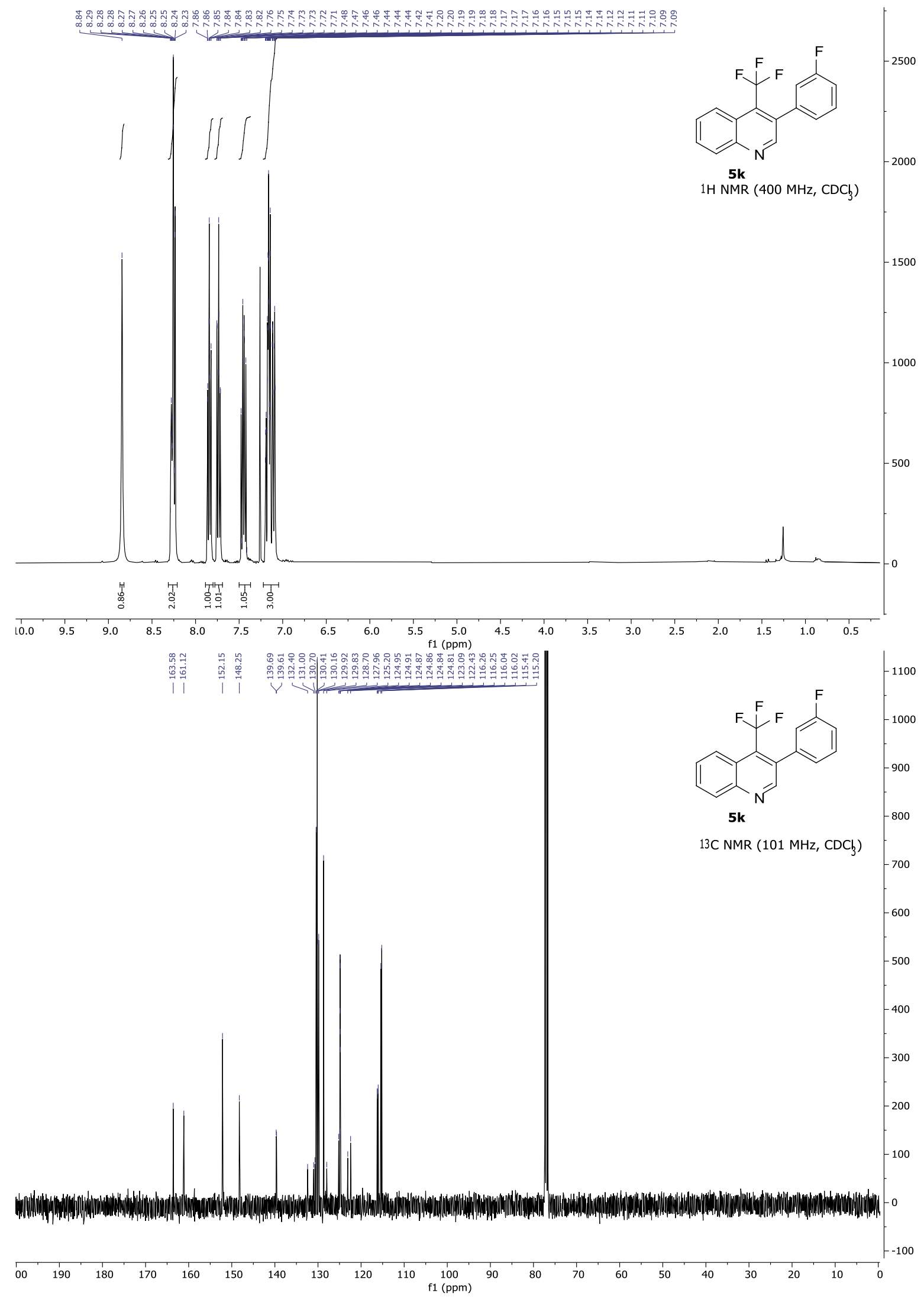




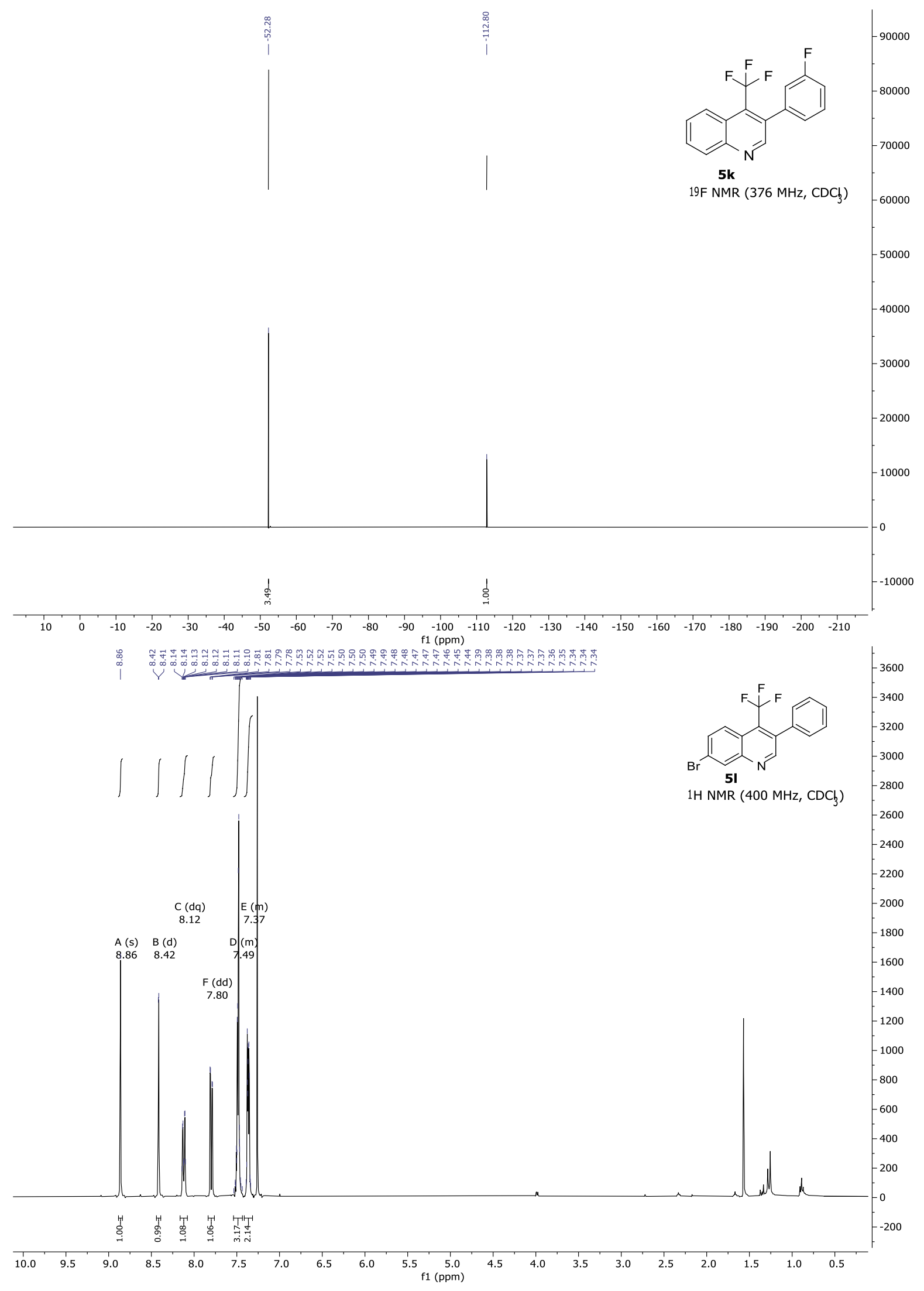




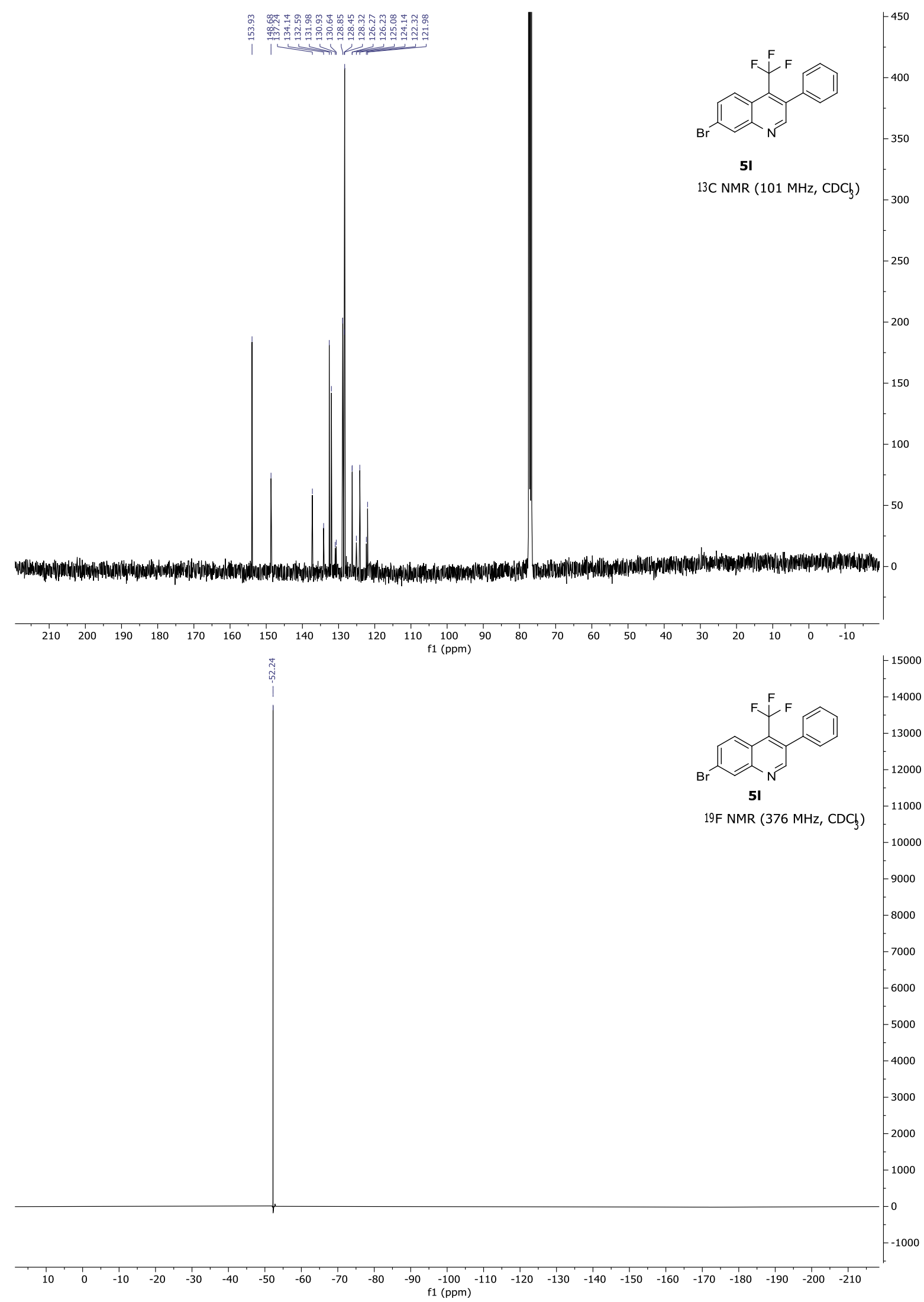




$$
I^{4}
$$




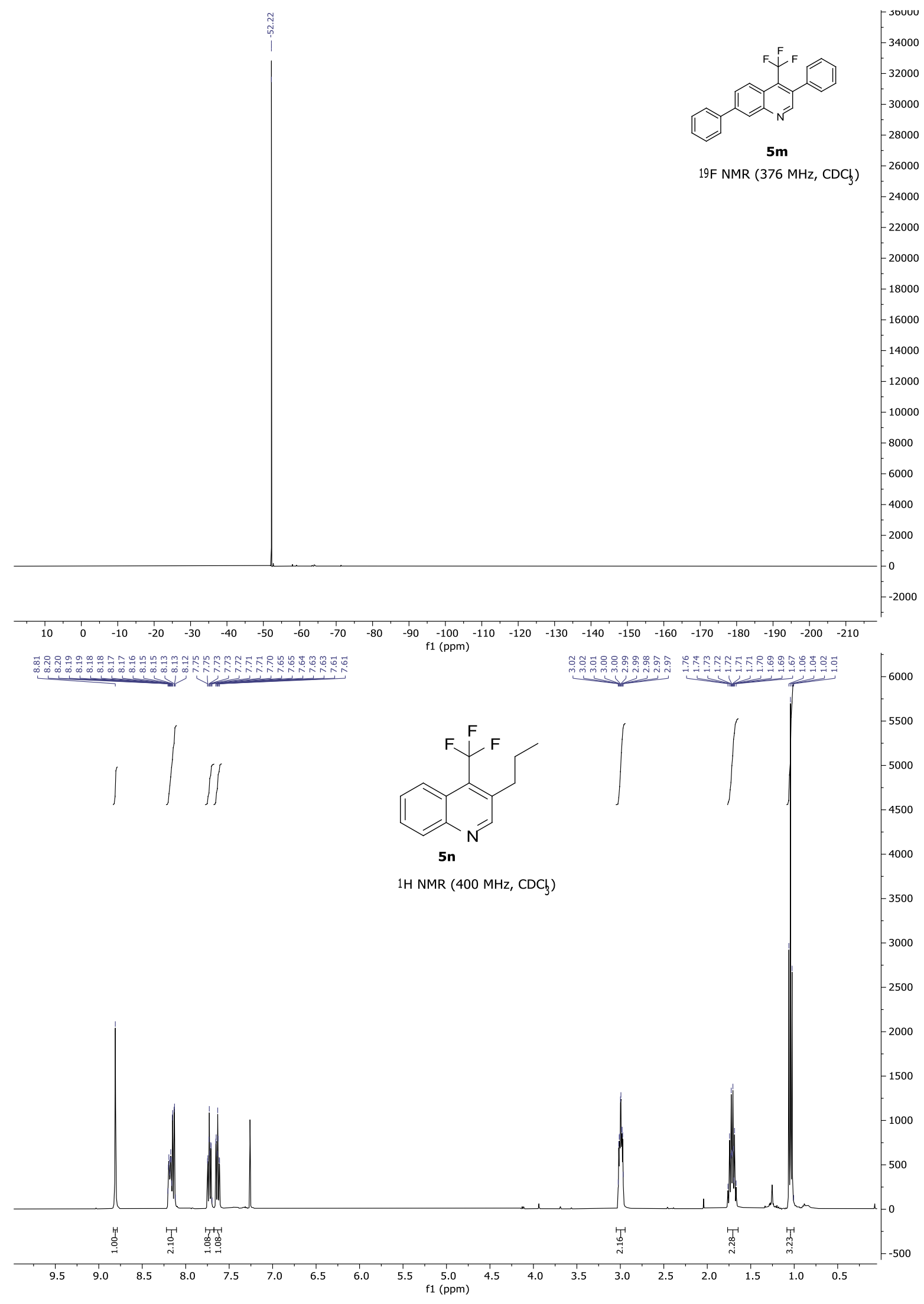




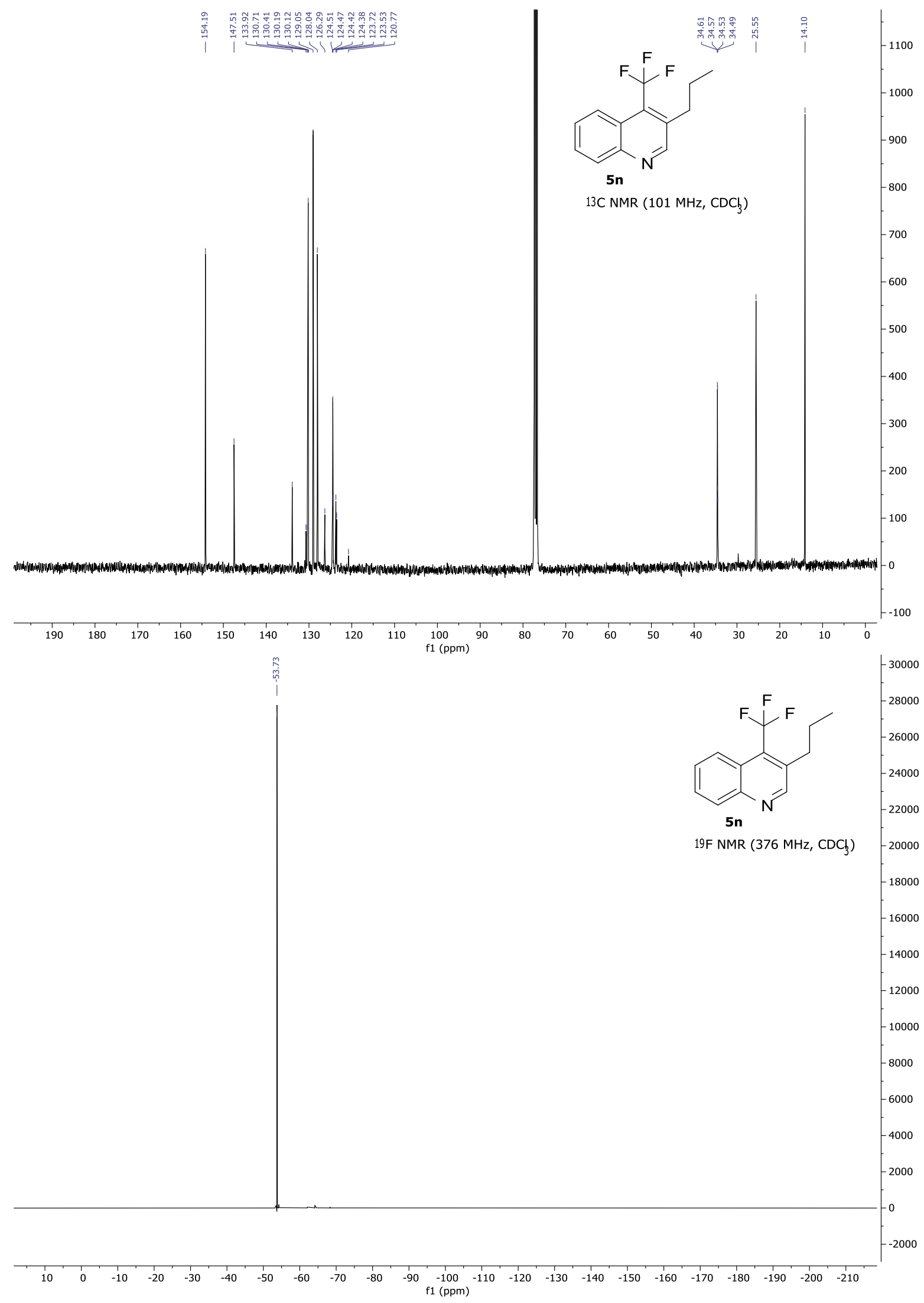




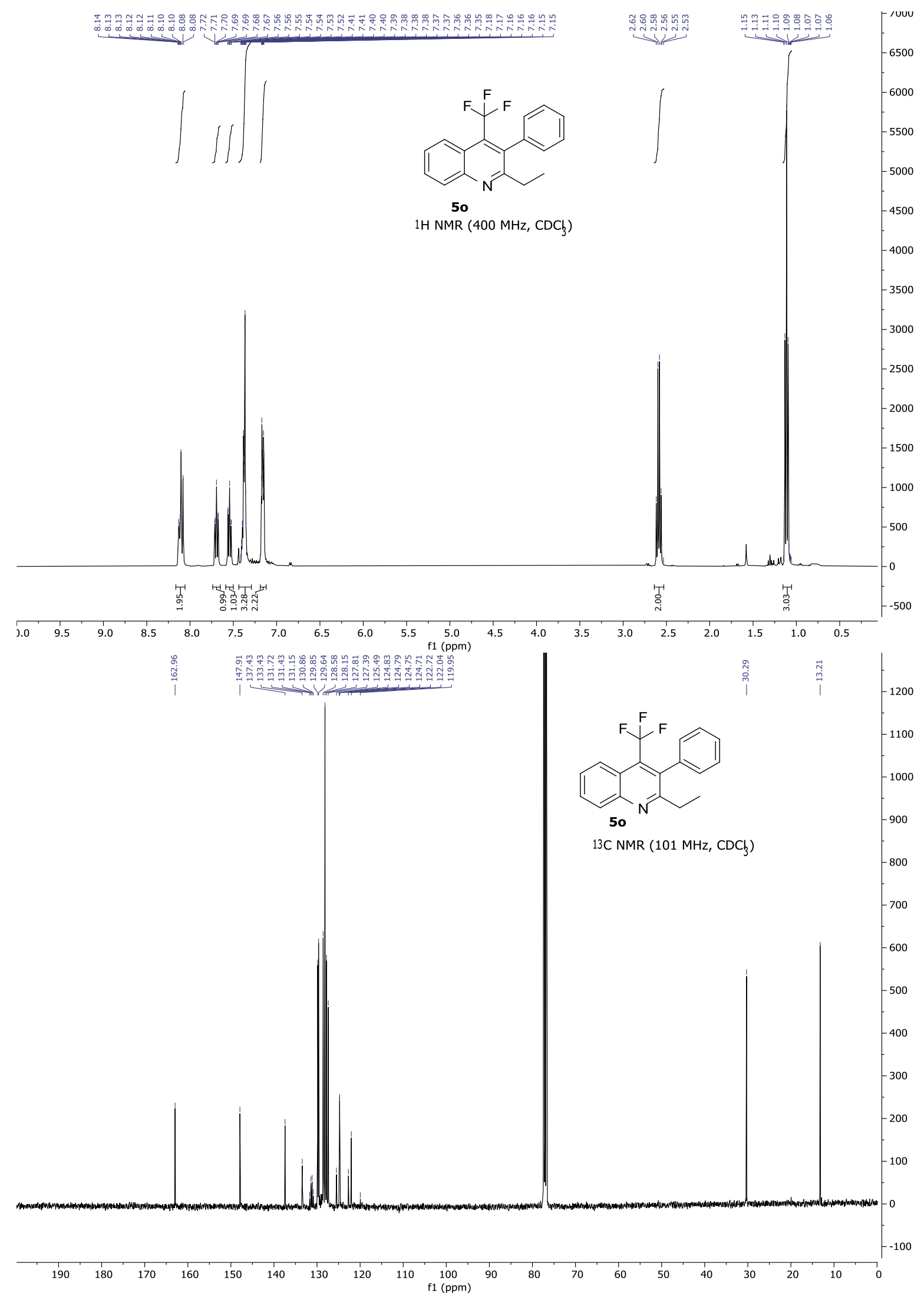



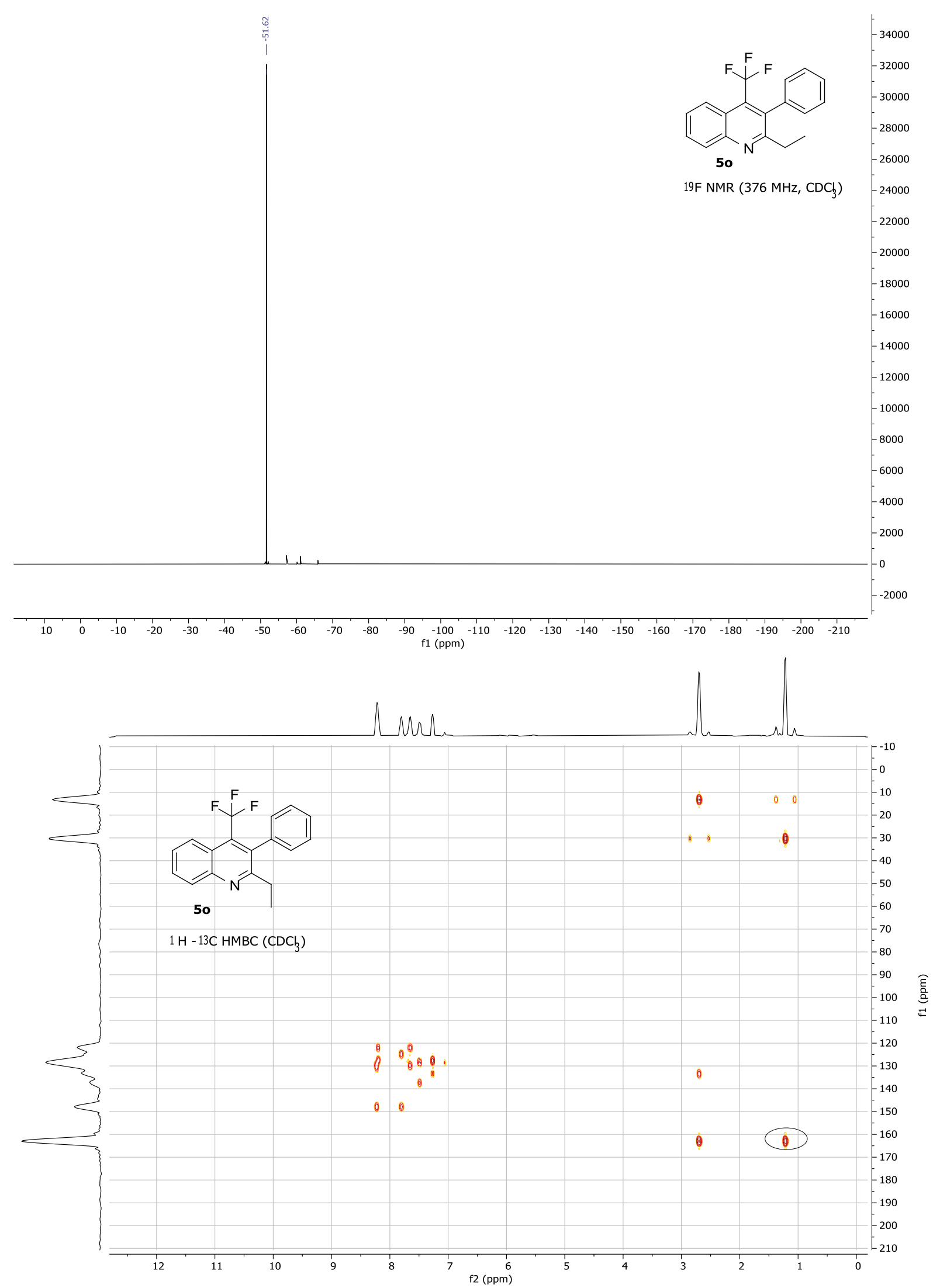


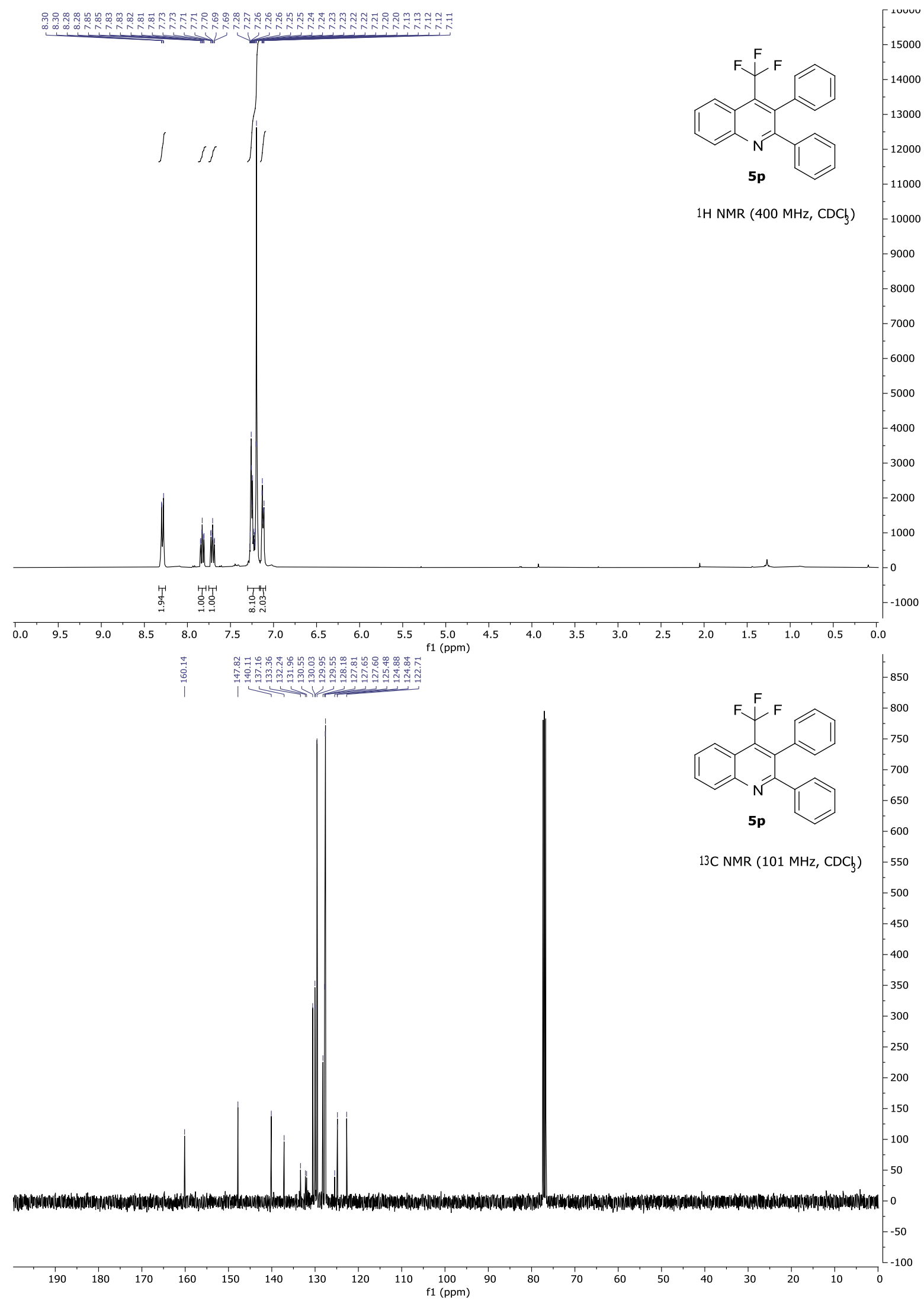




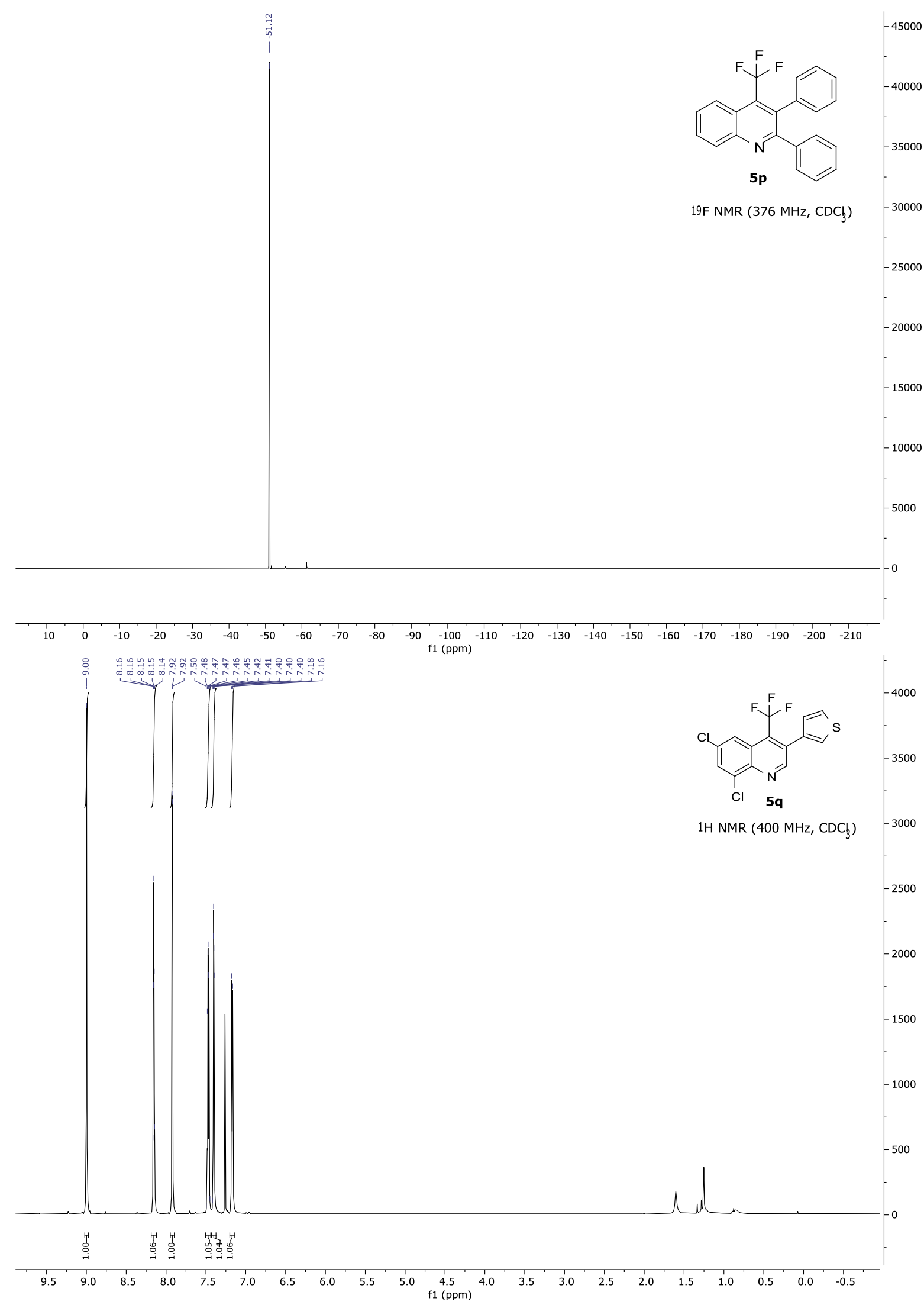




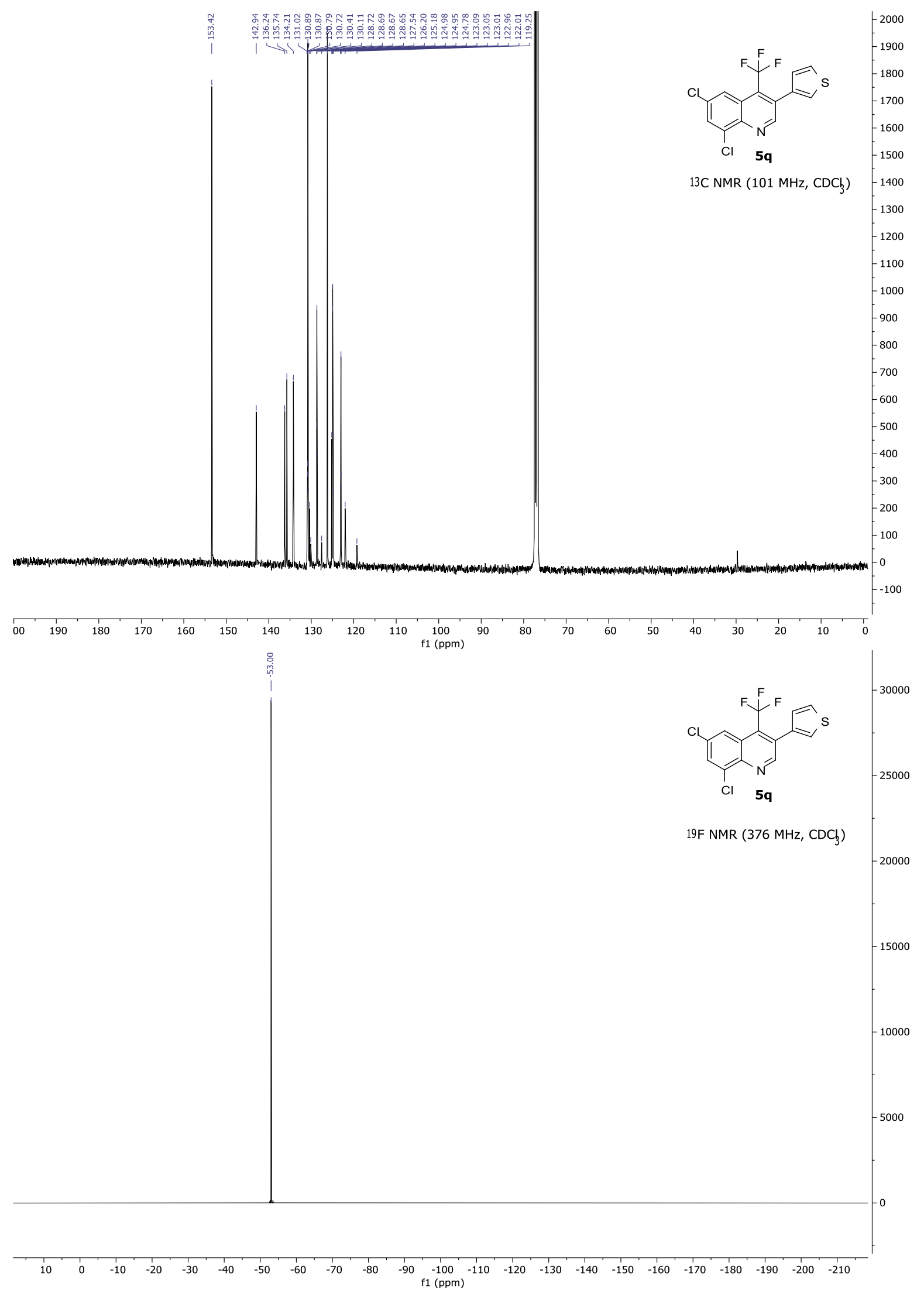




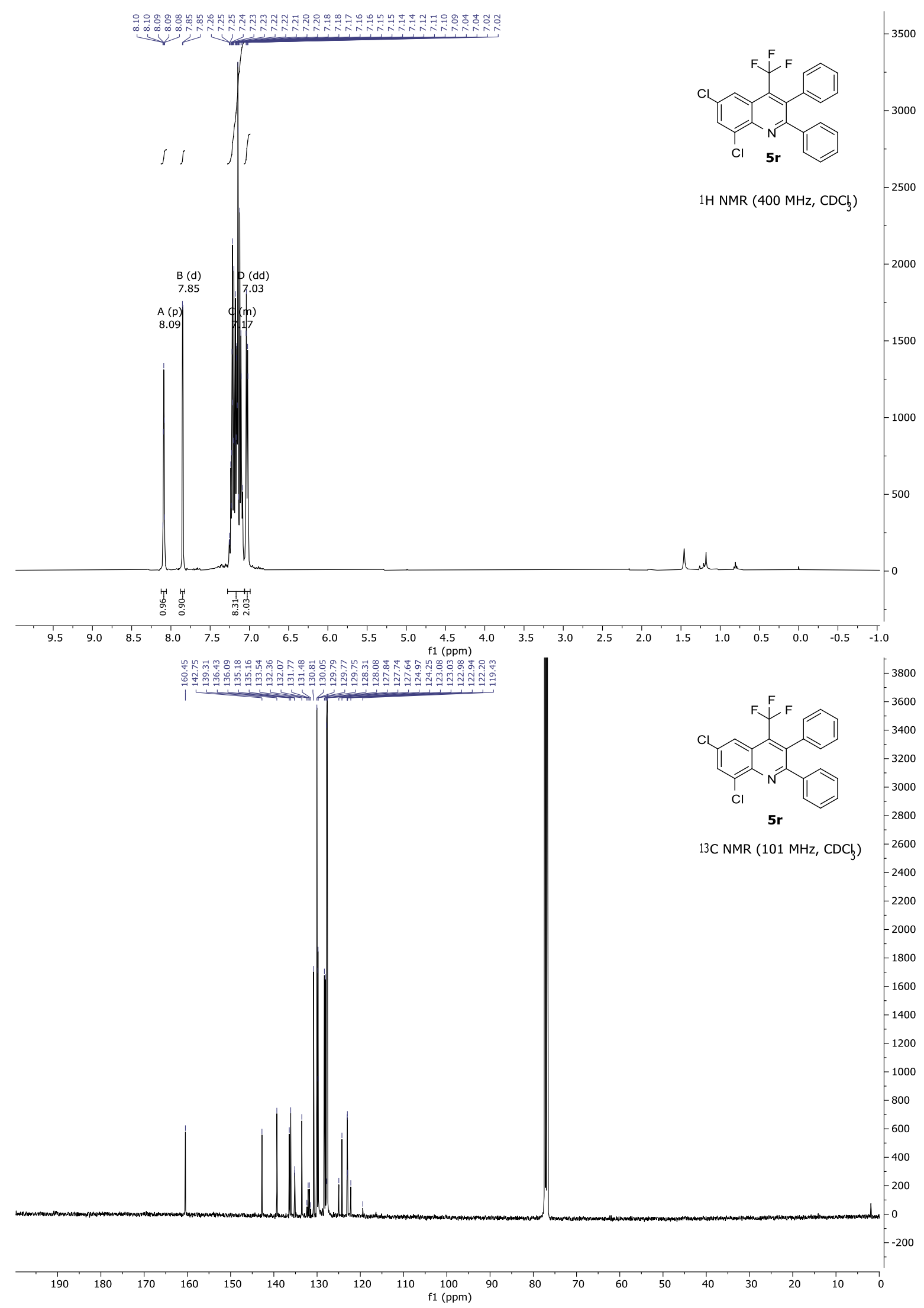




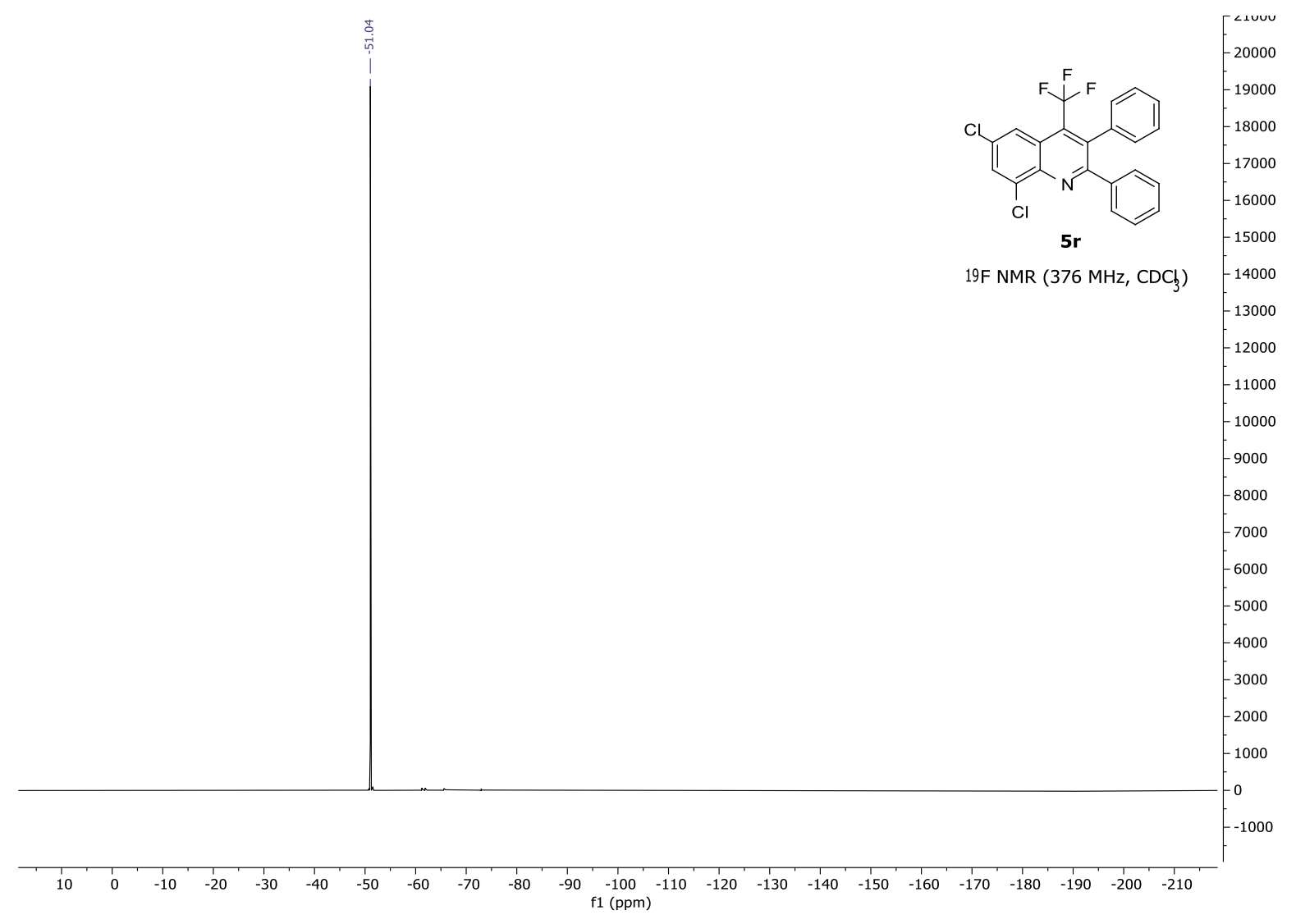

